\title{
A Study of the Relationship between Participation in Marietta College's McDonough Leadership Program and the Leadership Development of College Students
}

\author{
Dennis McNaboe \\ West Virginia University
}

Follow this and additional works at: https://researchrepository.wvu.edu/etd

\author{
Recommended Citation \\ McNaboe, Dennis, "A Study of the Relationship between Participation in Marietta College's McDonough \\ Leadership Program and the Leadership Development of College Students" (2011). Graduate Theses, \\ Dissertations, and Problem Reports. 3102. \\ https://researchrepository.wvu.edu/etd/3102
}

This Dissertation is protected by copyright and/or related rights. It has been brought to you by the The Research Repository @ WVU with permission from the rights-holder(s). You are free to use this Dissertation in any way that is permitted by the copyright and related rights legislation that applies to your use. For other uses you must obtain permission from the rights-holder(s) directly, unless additional rights are indicated by a Creative Commons license in the record and/ or on the work itself. This Dissertation has been accepted for inclusion in WVU Graduate Theses, Dissertations, and Problem Reports collection by an authorized administrator of The Research Repository @ WVU. For more information, please contact researchrepository@mail.wvu.edu. 
A Study of the Relationship between Participation in Marietta College's McDonough Leadership Program and the Leadership Development of College Students

\title{
Dennis McNaboe
}

Dissertation submitted to the College of Human Resources and Education at West Virginia University in partial fulfillment of the requirements for the degree of

\author{
Doctor of Education \\ in \\ Educational Leadership
}

\author{
Richard Walls, Ph.D., Co-chair \\ Kim Yousey-Elsener, Ph. D., Co-chair \\ Ernest Goeres, Ph. D. \\ Paul Chapman, Ph.D. \\ Allen Withers, Ph.D.
}

Department of Educational Leadership

Morgantown, West Virginia

2011

Keywords: Leadership, Leadership Development, College Students 


\section{ABSTRACT \\ A study of the relationship between participation in Marietta College's McDonough Leadership program and the leadership development of college students.}

\section{Dennis McNaboe}

This study assessed whether participation in the McDonough Leadership program had an effect on the leadership development of students at Marietta College. Participants from the freshman classes of 2007-2008 and 2008-2009 and graduating senior classes of 2010-2011 and 2011-2012 took the Kouzes and Posner (2005a) Student Leadership Practices Inventory - Self and the SLPI - Observer. Marietta College provided 26 surveys along with key demographic data, including gender, race, type of McDonough Scholars (International Leadership Studies Major, Leadership Studies Minor, and Certificate of Leadership Studies), and Experiential Learning Opportunity completed (None, Internship, Study Abroad, and Service Project).

Descriptive statistics, $t$-tests, and an analysis of variance (ANOVA) were used to analyze the data according to the research questions guiding this study. The major findings indicated that the participants in the McDonough Leadership Program $(N=50)$ made impressive gains from pre- to post-tests in the total scores and three of the five leadership practices (Challenging the Process, Inspiring a Shared Vision, and Modeling the Way) according to the SLPI - Self. However, according to the SLPI - Observer, no statistically significant results were found in the total scores or any of the five leadership practices.

Statistical significance was found in the interaction between the genders in Enabling Others to Act. However, no other statistically significant differences were revealed in the total scores or any of the other leadership practices according to the SLPI - Self. No statistical significance was found in the total scores or any of the leadership practices for the SLPI - Observer. No statistical significant differences between type of McDonough Scholars (International Leadership Studies Major, Leadership Studies Minor, and Certificate of Leadership Studies) were revealed in the total scores or any of the five leadership practices according to either the SLPI - Self or SLPI - Observer. No statistical significant differences between experiential learning opportunities (None, Internships, Study Abroad, Service Projects) were found according to either the SLPI - Self or the SLPI - Observer.

The specific gains in behavior as seen in the total scores and LP1, Challenging the Process, LP2, Inspiring a Shared Vision and LP4, Modeling the Way according to the SLPI - Self may suggest an increase in the general development of leadership skills and behaviors of Marietta College students participating in the McDonough Leadership Program. Additional research, however, needs to be conducted to determine the impact of the relationship between Marietta College's McDonough Leadership program and the development of college students. 


\section{DEDICATION}

This study is dedicated to my wife and best friend, Allyson Rae McNaboe. My passion to obtain my doctorate and the willingness to persist became real because of her support and sacrifices. Her humor helped to keep the daunting tasks in perspective. Her willingness to generously accept new and often challenging roles provided a safe and comfortable haven for me. Allyson's unwavering love and support for me were the catalysts for my strength and courage to prevail and to make my dream a reality.

I would also like to dedicate this project to my children Cadie Beth McNaboe and Isabella Hope McNaboe. Their support and love has been appreciated more than words can say. I was driven by their love for education and the need to serve them as a positive role model of what you can achieve if you dream and persevere.

Furthermore, this study is dedicated to my parents Dolores and Fred McNaboe. My life has changed since I was adopted by you and my love and admiration for each of you has grown each year we have been together. Your emotional and financial support helped make this all possible and I will be indebted to you forever.

\footnotetext{
Allyson, Cadie, Belle, Mom and Dad, I thank and love you very much!!!
}

Sincerely, Dennis McNaboe 


\section{ACKNOWLEDGEMENTS}

Those who have pursued a doctorate degree know only too well that the project cannot be completed in isolation. It is with a spirit of deep appreciation and thankfulness that I acknowledge the following contributors to my successful completion of the doctoral program:

I have experienced many challenges including numerous members of my dissertation committee and several topic changes. I extend my heartfelt appreciation to all of my many committee members for their guidance throughout the journey. I would like to pay particular attention to members of my committee who have stood with me and helped me overcome these difficult challenges, making the completion of this process worthwhile:

- Dr. Richard Walls, Chairperson

- Dr. Kim Yousey-Elsener, Co-Chairperson

- Dr. Ernest Goeres

- Dr. Paul Chapman

- Dr. Allen Withers

I would like to recognize the tremendous efforts of my chairpersons, Dr. Walls and Dr. Yousey-Elsener. Dr. Walls, I appreciate all of your time and dedication and thorough feedback which made this a positive learning experience and made the end result something I can be proud of. Dr. Yousey-Elsener, I sincerely appreciate all of your hard work and guidance throughout the process, and the many hours you've spent communicating with me over the last several weeks. 
I would like to pay special tribute to Allen Withers, who has not only served as a member of my committee and my immediate supervisor at Alderson-Broaddus College, but has also served as a mentor and friend. Allen has become someone l've come to rely upon and I thank him for all of his support and assistance throughout the years. In addition, I am extremely grateful to many individuals who helped bring this project to fruition. These individuals served as my personal cheering section:

- My father and mother in-law, John and Connie Armentrout, who took on additional family roles that helped make this journey possible. John and Connie have been there from the beginning and have served as guides (I wouldn't have made it back and forth from Keyser without them), counselors (listening to me express my concerns and frustrations), and role models (having journeyed the graduate road before me).

- Roxanne Bright, who has been one of my closest friends and has often been my "partner in crime". In addition, I would like to recognize my colleagues and friends at Alderson-Broaddus College, including Amanda Jones, Patty Bowmar, Cindy Wanamaker, Chad Hostetler, Chad Plymale, Dr. and Mrs. Jim Wilkie, and Jessica Stein. In addition, I will forever remember the support of Dr. and Mrs. Steven Markwood, Dr. and Mrs. Dennis Stull, Tanya Shelton, and Bruce Blankenship.

- My colleagues who were members of the Eastern Panhandle Cohort, and in particular Philip Keith and Karen Posa, I followed in your footsteps and will forever appreciate your friendship. 
- Juanita Coleman, who has been a great friend and a tremendous resource for me, as I have taken on new professional opportunities. The friendships I have made with the Fairmont State University staff, while new, have been integral to helping me achieve my professional and educational goals. I give special thanks to Dr. Quentin Johnson, Raime Santee, Jennifer Weist and Laurie Johnston.

- My church family who helped me through my trials and tribulations with their guidance, wisdom, and prayers. In particular I would like to thank Reverend Marvin Parli, who has served as my friend, mentor, and spiritual advisor. Also, I would like to thank: T.R. Eidell, the Deacon Board, Curtis Corley, Rhonda Coffman, Evelyn Thorn, Evelyn Lange, and Jeff Menendez.

- It is gratifying for me to finally have an opportunity to acknowledge my entire family for the many blessings they have bestowed upon me throughout my life. I express my appreciation to them for their willingness to love and support me throughout the years. A special thanks goes out to Patricia and Steve Hutton and Francis and George Stasko. 


\section{Table of Contents}

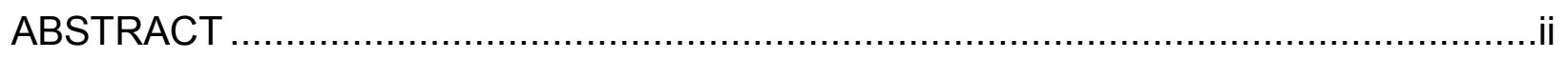

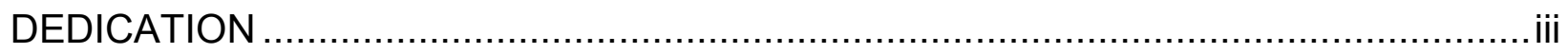

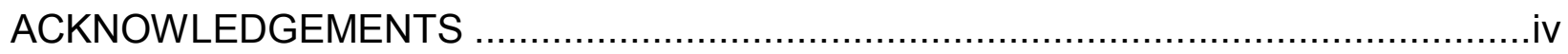

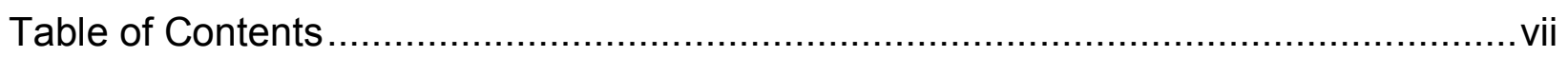

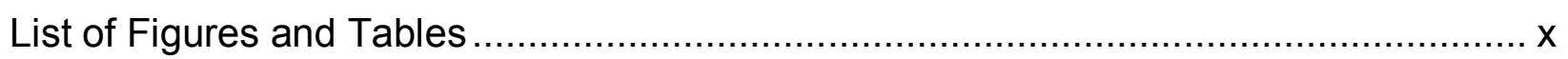

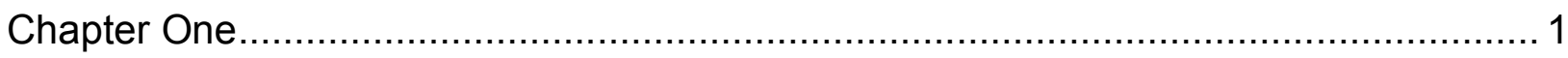

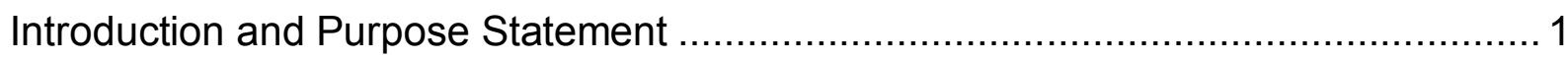

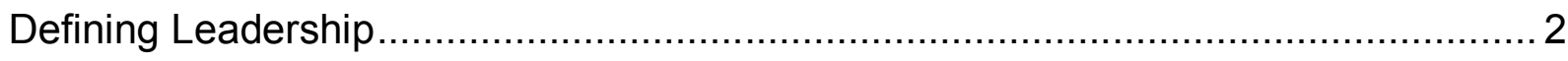

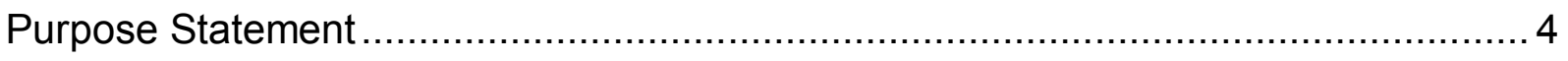

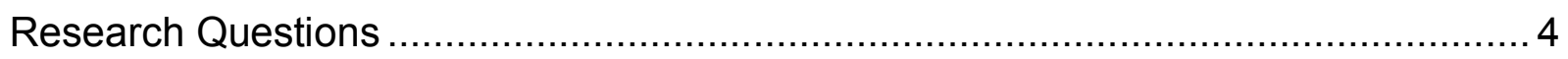

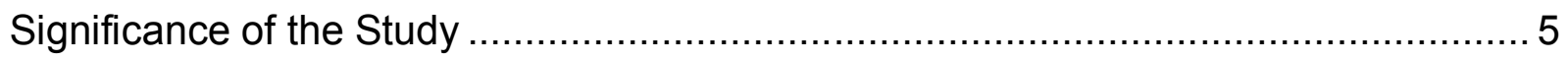

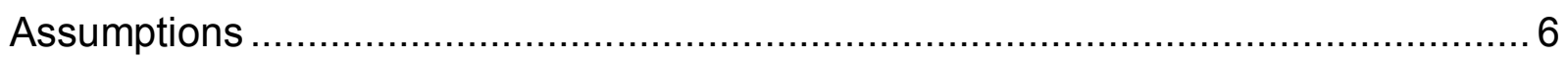

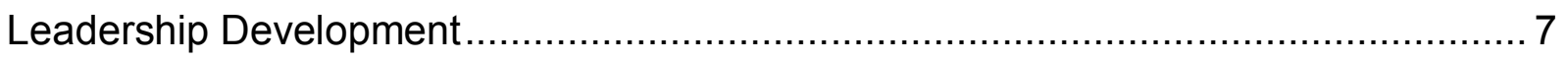

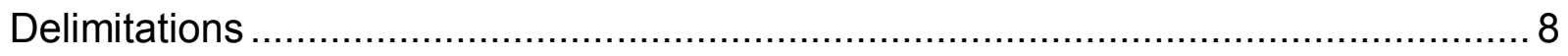

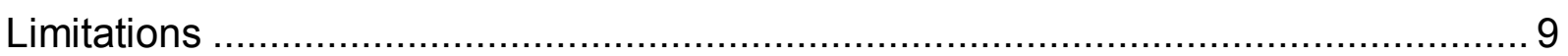

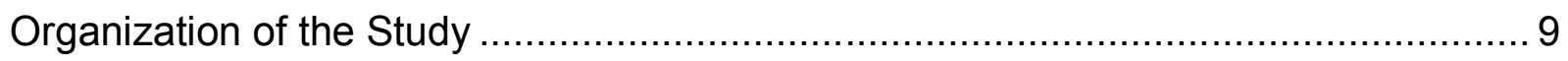

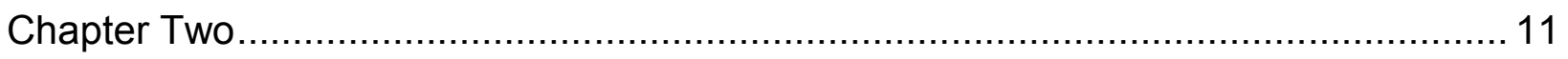

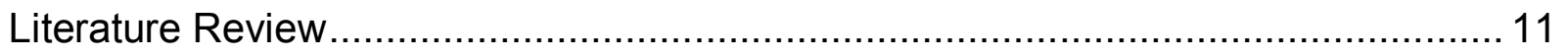

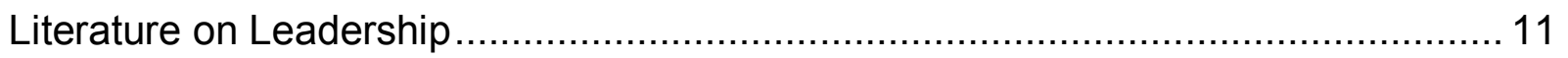

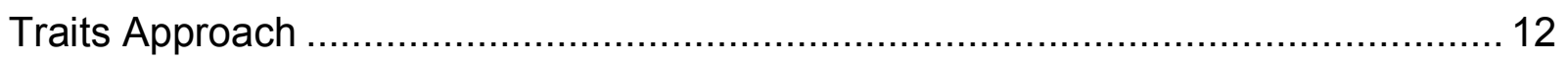

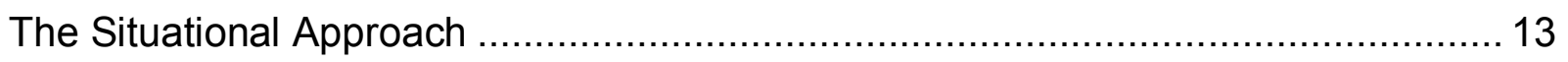

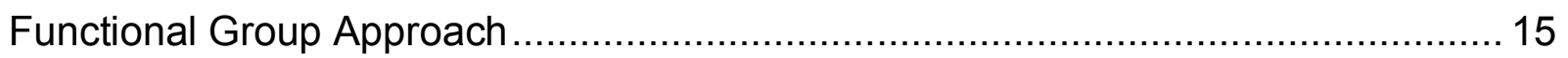

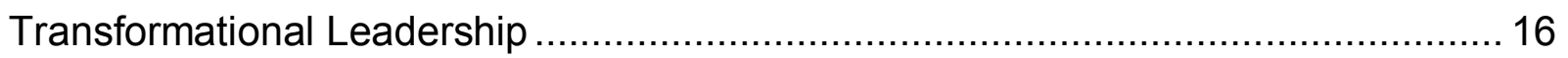

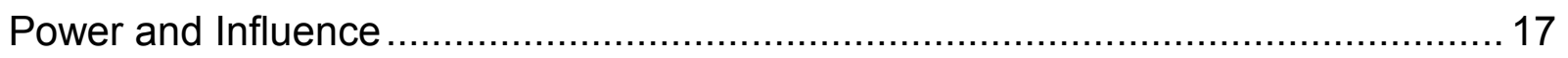

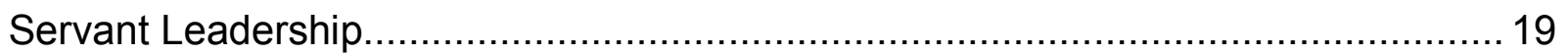

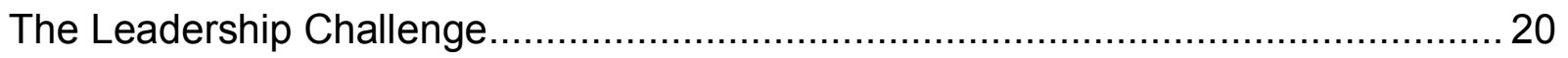

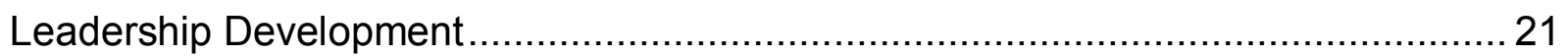

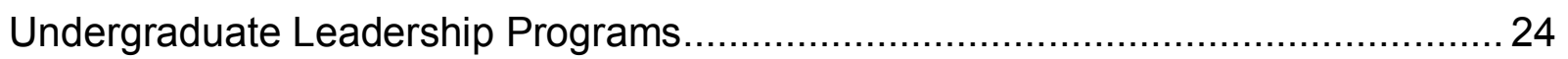

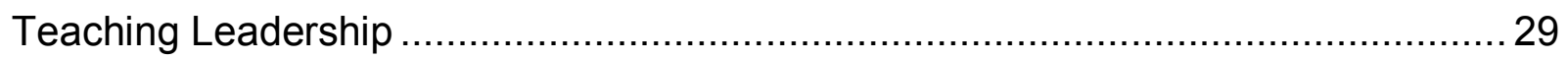

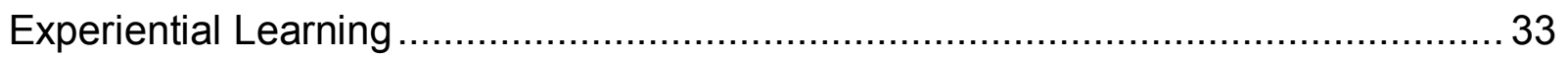

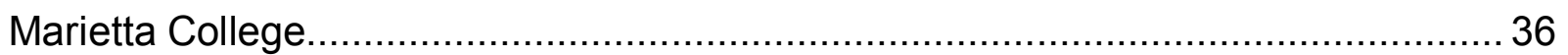

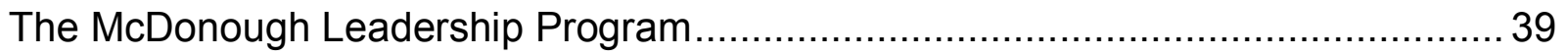

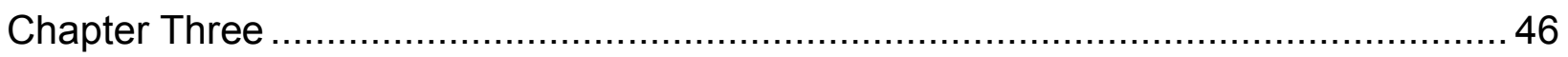




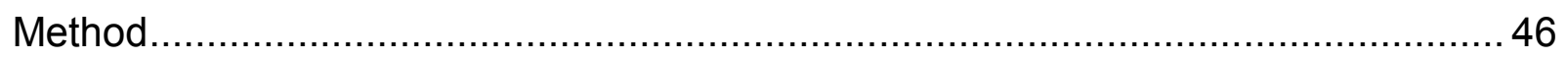

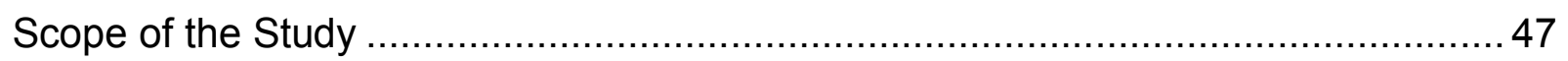

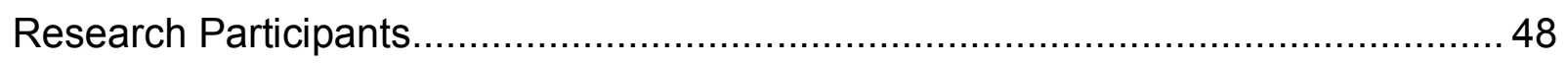

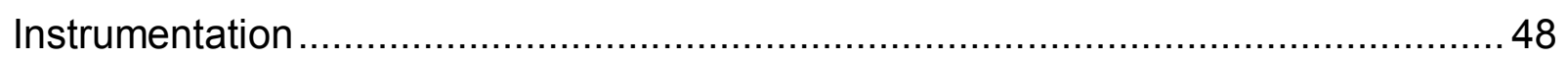

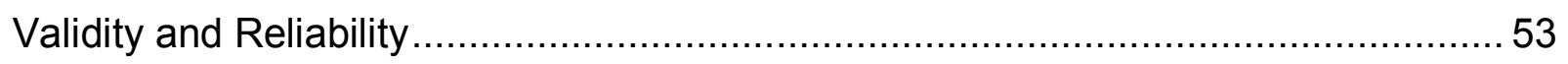

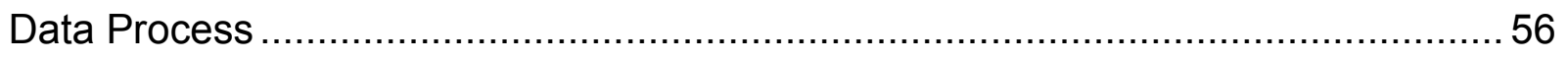

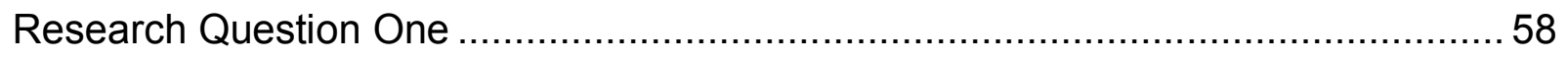

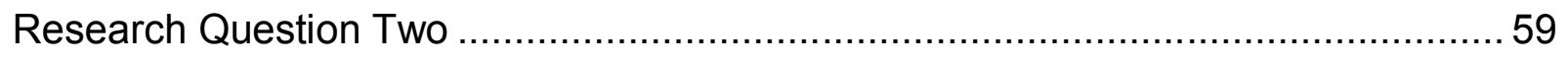

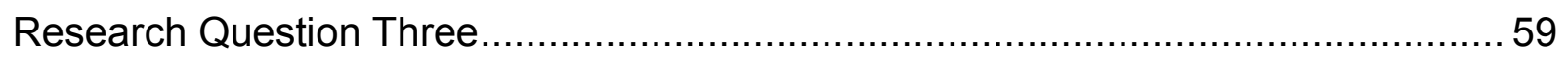

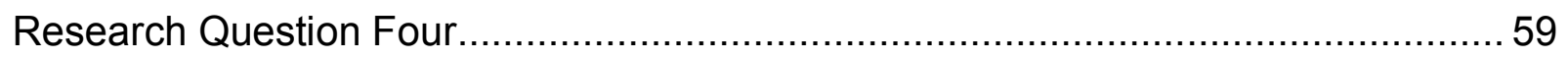

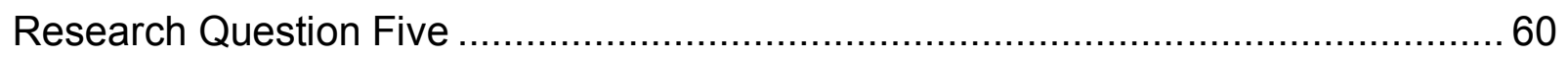

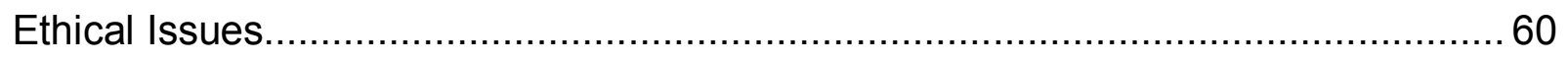

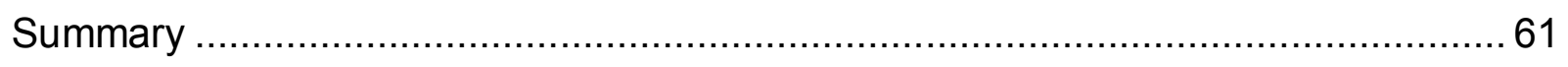

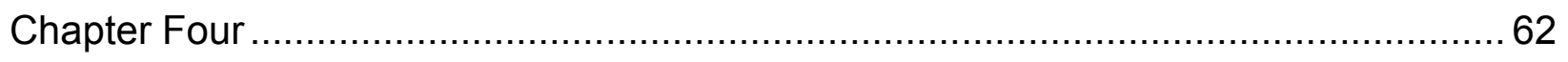

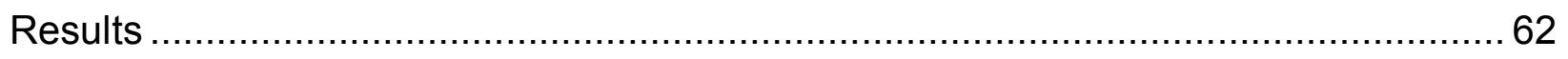

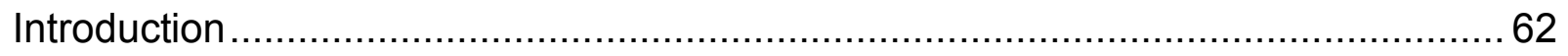

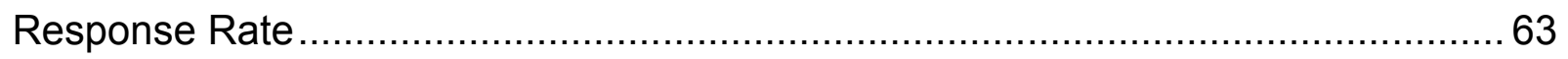

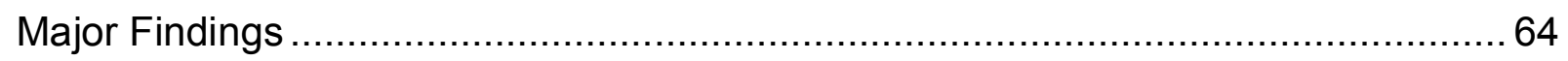

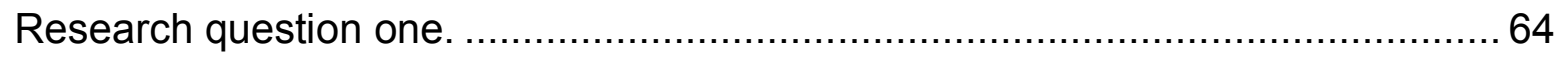

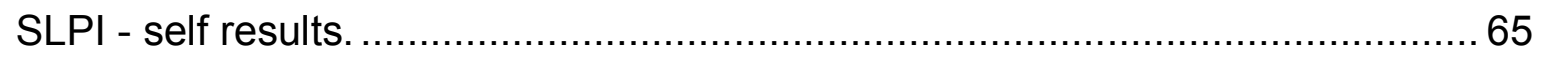

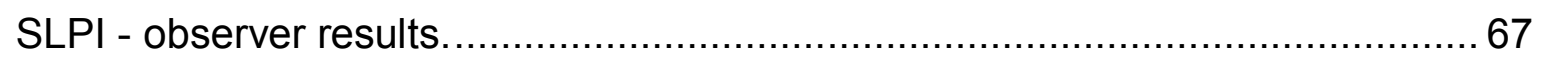

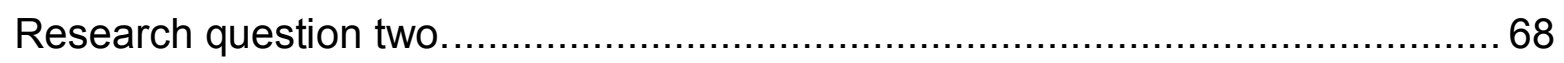

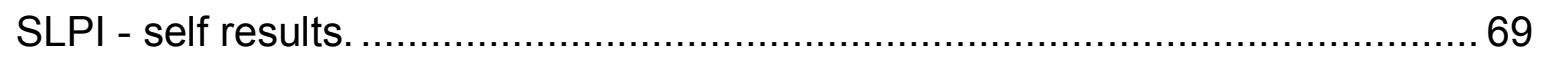

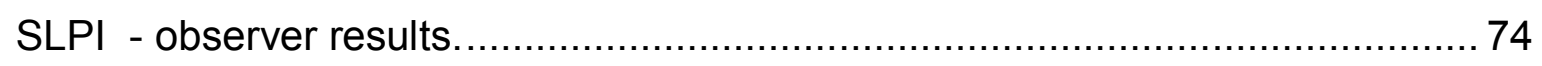

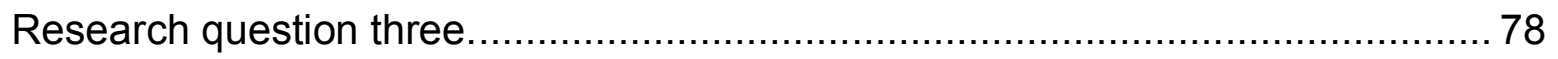

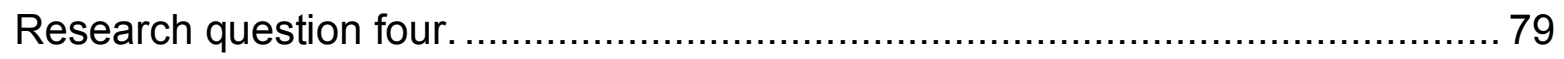

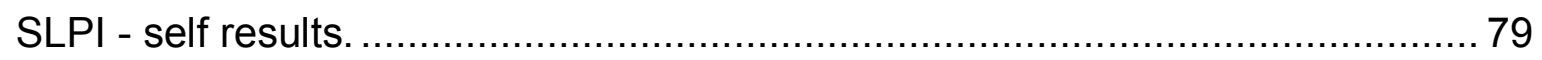

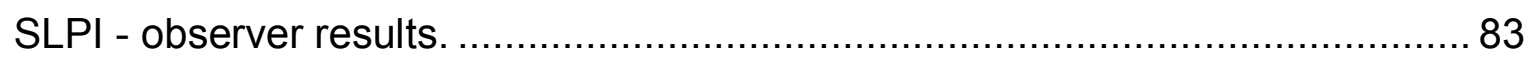

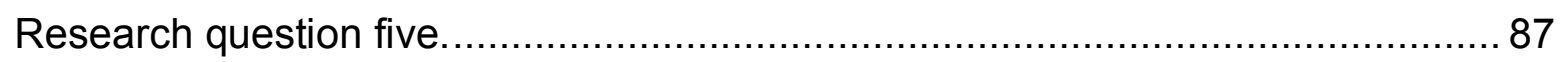

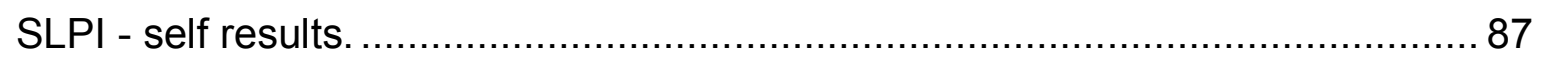

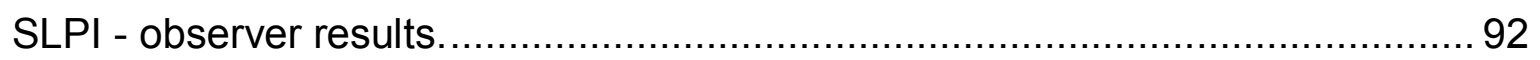

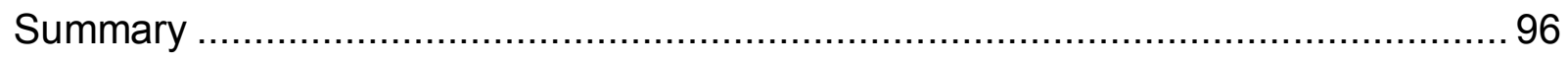

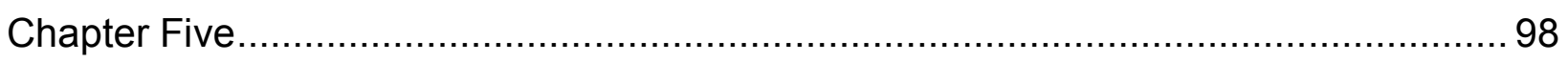

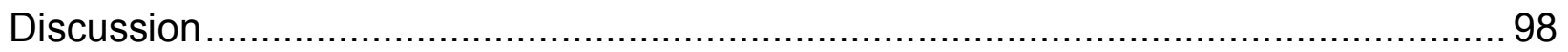




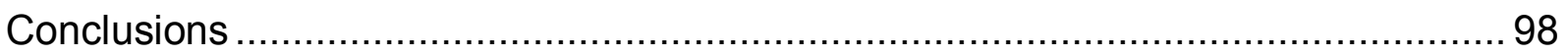

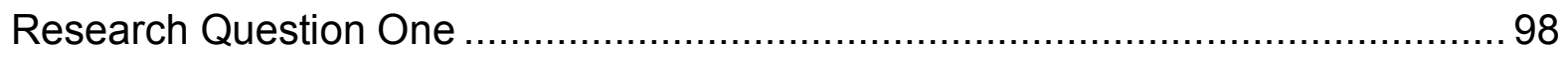

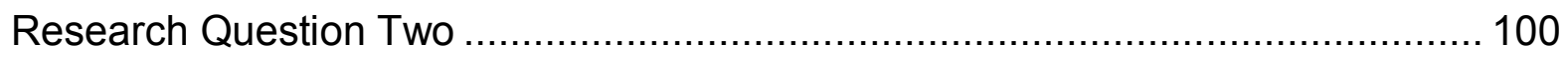

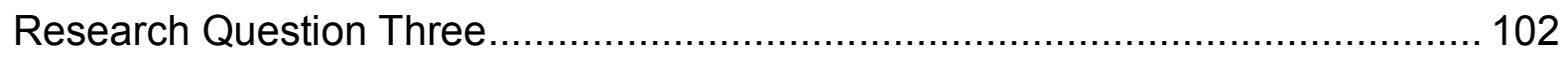

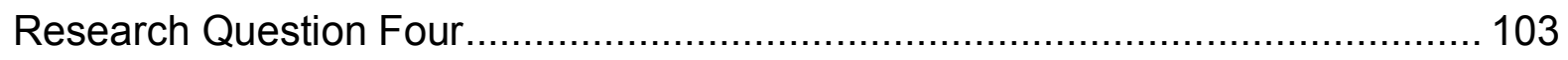

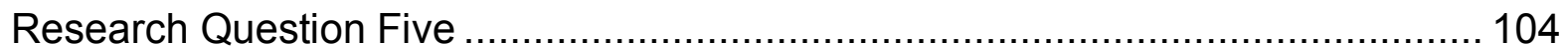

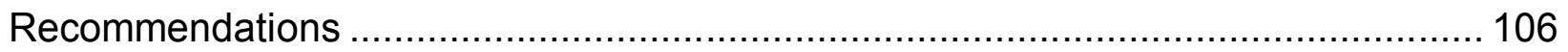

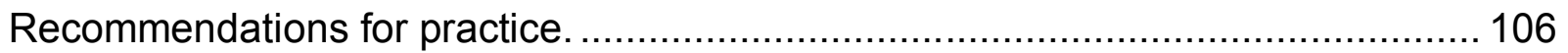

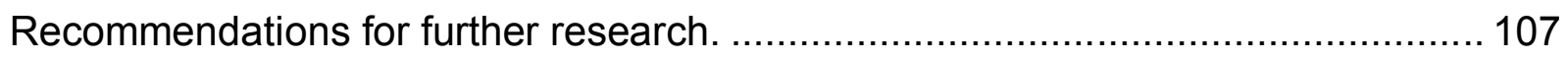

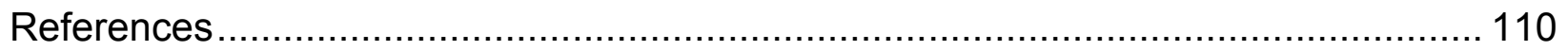

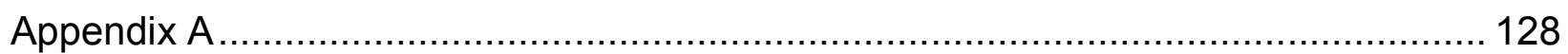

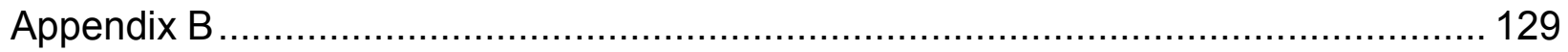

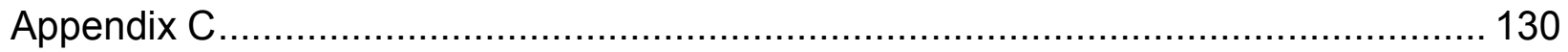

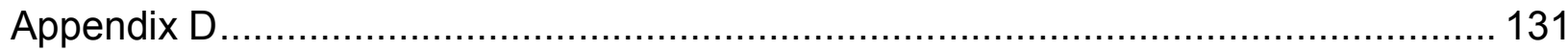

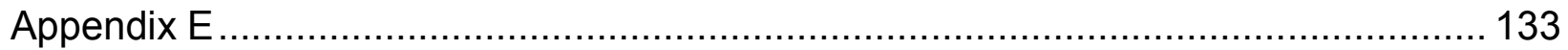




\section{List of Figures and Tables}

Table 1 Student Leadership Practices Inventory (SLPI) Item Breakdown ....................51

Table 2 T-Tests to be Calculated for Research Question 1 ......................................58

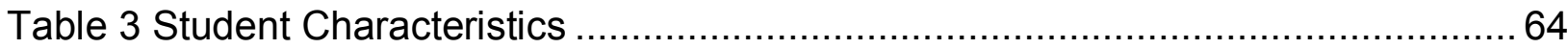

Table 4 The Pre-Test and Post-Test Scores on the SLPI - Self ................................6 65

Table 5 The Pre-Test and Post-Test Scores on the SLPI - Observer...........................68

Table 6 Gender and the Pre-Test and Post-Test Scores on the SLPI - Self ................ 71

Figure 1 LP3, Enabling Others to Act for Gender (SLPI - Self) …........................... 70

Table 7 Gender and the Pre-Test and Post-Test Means and SD on the SLPI - Self..... 72

Figure 2 LP4, Modeling the Way for Gender (SLPI - Self) ................................... 74

Table 8 Gender and the Pre-Test and Post-Test Scores on the SLPI - Observer..........75

Table 9 Gender and Means and SD on the SLPI - Observer...............................76

Figure 3 LP5, Encouraging the Heart for Gender (SLPI - Observer) ........................ 77

Table 10 Type of McDonough Scholar and Pre/Post-Test Scores on SLPI - Observer. 80

Table $11 \mathrm{McD}$ onough Scholars and the Means and SD on the SLPI - Self...................81

Figure 4 LP3, Enabling Others to Act for McDonough Scholar (SLPI - Observer) ........ 84

Table 12 Type of McDonough Scholar and Pre/Post-Test Scores on the SLPI - Self ... 85

Table 13 McDonough Scholars and the Means and SD on the SLPI - Observer ..........8 86

Figure 5 Total Scores for Experiential Learning Opportunity (SLPI - Self) ....................8 87

Table 14 Experiential Learning and Pre/Post Test Scores on the SLPI - Self ............... 88

Figure 6 LP3, Enabling Others to Act for Experiential Learning (SLPI - Self)...............99

Table 15 Experiential Learning and the Means \& SD on the SLPI - Self...................... 91

Table 16 Experiential Learning and Pre/Post-Test Scores on the SLPI - Observer ...... 94

Table 17 Experiential Learning and the Means \& SD on the SLPI - Observer .............. 95 


\section{Chapter One}

\section{Introduction and Purpose Statement}

There is a growing amount of research on the effects of leadership development activities among college students (Kezar \& Moriarty, 2000). In addition, there is an increasing interest in understanding the effects of the learning that occurs through offcampus community based and experiential learning opportunities and its relationship to developing student leaders (Campus Compact, 2007; Flannery, 1999; Ngai, 2006).

Little empirical research, however, exists on the relationship between leadership development programs and the development of leadership behaviors among college students. This study examined the relationship between participation in Marietta College's McDonough Leadership Program and the leadership development of college

students. Special attention was given to the experiential learning opportunities required of students who participated in the McDonough Leadership Program and the role those experiences play in developing leadership skills and behaviors.

\section{Leadership Development}

There is little question about the importance of leadership development among college students. The W.K. Kellogg Foundation noted our society needs more and better leaders, and the college environment is a strategic setting for learning the necessary skills and theories to be an effective leader (Astin \& Cress, 1998).Leadership development in colleges and universities makes sense because "when it comes to describing its educational mission, the typical college or university will use language such as 'preparing students for responsible citizenship,' 'developing character,' 
'developing future leaders,' 'preparing students to serve society,' and so forth" (Astin, 1997, p. 4).

The study of leadership development is steadily increasing in higher education (Kezar \& Moriarty, 2000). The Council for the Advancement of Studies (CAS) recognizes the importance of contemporary leadership development programs which focus on "an inherently relational process of working with others to accomplish a goal or to promote change" (Miller, 1997, p. 111). CAS (2006) noted that one of the key principles in an effective leadership development program is that it should provide students with opportunities to better understand themselves, others, and their community, while recognizing the importance of accepting responsibility. In addition, CAS recommended the provision of multiple delivery formats, strategies, and contexts as part of a comprehensive leadership program.

\section{Defining Leadership}

Leadership has long been a topic of interest to people (Adair, 1989; Burns, 1978; Gardner, 1990). The premise of situational leadership and the connection to the underlying cognitive skills needed to succeed in these situations is attributed to Socrates (Adair, 1989). However, defining and understanding leadership and leadership education is challenging. Some experts have suggested that defining leadership is nearly impossible and training leaders is akin to going on a snipe hunt (McCorkle, 1998). Society is enticed by the appeal of being leaders, of developing leadership courses, of making leaders out of students, and of contributing to better citizens. But how is leadership defined in order to develop it? 
Bennis and Goldsmith (1997) wrote about leadership metaphorically as a stool, built upon the legs of integrity, competence, and ambition. Bennis and Goldsmith also identified four qualities of leadership as vision, empathy, consistency, and integrity. However, even within their own text, there is some variation in the definition of the attributes of effective leaders. This provides further evidence that pinning down a definition of leadership is a daunting task.

Ralph Stodgill (1974) suggested that there are almost as many definitions of leadership as there are persons who have attempted to define the concept. Some have defined leadership as an art and others as a science. A more thorough look at the many definitions of leadership can be found in the literature review; however here is an attempt to give some background of how leadership has been defined over the years.

Bennis and Nanus (1997) suggested that leadership is like the abominable snowman, whose footprints are everywhere but who is nowhere to be seen. Napoleon Bonaparte believed that a leader is a dealer of hope (Paul, 2010). Warren Bennis' (1989) definition of leadership is focused much more on the individual capability of the leader. He states that "Leadership is a function of knowing yourself, having a vision that is well communicated, building trust among colleagues, and taking effective action to realize your own leadership potential” (p. 139).

Peter Drucker (1999) suggested that leadership is not about a list of attributes as no two leaders will exhibit the same list, nor is it about charisma or some king-like quality. It is instead all about delivery of performance like that of a manager. Steven R. Covey (1989) differentiates leadership from management. Covey believes 
management is efficiency in climbing the ladder of success. Leadership, Covey suggested, determines whether the ladder is leaning against the right wall (1989).

Kouzes and Posner (2002) note that "leadership is the art of mobilizing others to want to struggle for shared aspirations" (p. 30). Others believe leadership is a purposeful relationship, which occurs when individuals use their skills to influence and advocate for transformative change (Kearns, 2005).

\section{Purpose Statement}

The purpose of this study is to explore the relationship between participation in the Marietta College McDonough Leadership program and undergraduate student leadership development. Consideration is also given to the relationship between genders, major, race, and participation in experiential learning and student leadership development. Kouzes and Posner's (2005a; 2005b) Student Leadership Practices Inventory (SLPI) - Self (Appendix D) and Observer (Appendix E) pre-test and post-test surveys were utilized to answer the following research questions.

\section{Research Questions}

The primary research questions guiding this study include:

1. After participating in the McDonough leadership program at Marietta College, do college students demonstrate significant gains in the development of leadership behaviors as measured by the SLPI - Self and SLPI - Observer, according to the five leadership dimensions of Modeling the Way, Inspiring a Shared Vision, Challenging the Process, Enabling Others to Act, and Encouraging the heart? 
2. As measured by the SLPI - Self and SLPI - Observer, is there a statistically significant difference in the development of leadership behaviors by gender after participating in the McDonough leadership program at Marietta College?

3. As measured by the SLPI - Self and SLPI - Observer, is there a statistically significant difference in the development of leadership behaviors by race after participating in the McDonough leadership program at Marietta College?

4. As measured by the SLPI - Self and SLPI - Observer, is there a statistically significant difference in the development of leadership behaviors by the type of McDonough Scholar including International Leadership Studies major, Leadership Studies minor, and Certificate of Leadership Studies after participating in the McDonough leadership program at Marietta College?

5. As measured by the SLPI - Self and SLPI - Observer, is there a statistically significant difference in the development of leadership behaviors by the type of experiential learning opportunity including internship, study abroad, and service project after participating in the McDonough leadership program at Marietta College?

\section{Significance of the Study}

While the development of leadership programs is not new, there has been a rebirth in utilizing experiential learning efforts as a method of developing leaders (Hattie, Marsh, Neill, \& Richards, 1997). Leadership development programs like Marietta College's McDonough Leadership program continue to utilize experiential efforts to develop leaders. 
Early evaluations of experiential learning efforts to develop student leaders have relied upon statements of faith rather than methodological research. There has been a greater level of interest in recent years to better understand the relationship experiences like community service projects, study abroad trips, and internships have in developing leaders.

The significance of this study is to add to the dearth of research on the relationship between programs like Marietta College's McDonough Leadership Program and the development of leadership skills and behaviors among college students. In addition, this research will examine the specific behavioral changes and growth seen in students as a result of experiential learning opportunities like community service projects, study abroad trips, and internships.

Given the increased competition for students and the challenges of the economy, this study can provide administrators with information about the impact experiential learning opportunities have on students and their development. The in-depth quantitative data this study can provide about the impact these experiences have on the development of students as leaders, can arm administrators with useful information that they can use to justify why these types of experiences are crucial to sustain over time for undergraduates.

\section{Assumptions}

- The data collected were dependent upon, and assume the honesty and integrity of participants throughout the data collection process.

- Experiential learning is of significant importance in leadership development. 
- Marietta College and the participants of the McDonough Leadership program were willing to participate in the study.

\section{Leadership Development}

As with the term leadership, leadership development has no agreed upon definition. In this section, several definitions are considered and a final definition is proposed.

Scholars have defined leadership development in the following ways:

- 'Leader development is the expansion of a person's capacity to be effective in leadership roles and processes" (McCauley \& Van Velsor, 2005, p. 2).

- “Leadership development is the expansion of the organization's capacity to enact the basic leadership needed for collective work: setting direction, creating alignment, and maintaining commitment" (McCauley \& Van Velsor, 2005, p. 18).

- "Not a program or a one shot training process. It is a system that takes into account how your organization functions, what it rewards, and what it values" (Sindell \& Hoang, 2001, p. 2).

- "It can be viewed as a planned intervention in the life stream, where given a particular model, method, time period, and evaluation strategy, we expect to change the course in people's mental model, behavior, and direction of the life stream" (Avolio, 2005, p. 169).

- "Leadership development is the act of expanding the capacities of individuals, groups and organizations to participate effectively in leadership roles and capacities" (Day, 2004, p. 841). 
- According to the US Army, "Leader development is [a] continuous, progressive, and sequential process through which leaders acquire skills, knowledge and behavior necessary to maintain a trained Army in peace-time to deter war" (O’Neil \& Fisher, 2004, p. 102).

- Avolio (2004) defines development as "changes that occur over time due to both maturational processes and learning" (p. 127-128).

- At its best, leadership development should inspire and enable leaders to higher and higher levels of achievement" (Vicere \& Fulmer, 1996, p. 17).

- Leader development is "individual-based knowledge, skills and abilities associated with formal leadership roles" (Day, 2001, p. 584).

- Leadership development focuses on "building and using interpersonal competence...key components of interpersonal competences include social awareness and social skills" (Day, 2001, p. 585).

In an effort to synthesize the definitions described above, this research will utilize the following definition of leadership development defined by the researcher:

Leadership development is a continuous, systemic process designed to expand the capacities, competencies, and awareness of individuals, groups, and organizations in an effort to meet shared goals and objectives and inspire higher levels of achievement.

\section{Delimitations}

While there are numerous leadership programs serving college students in the United States, Marietta College's McDonough Leadership Program was chosen due to its rich history. Marietta College's McDonough Leadership Program was first developed 
as a certificate of study in 1987 and has since progressed to include a minor and a major in international leadership studies. This study was conducted in the spring and fall of 2011 .

Data from both the SLPI - Self and SLPI - Observer will be utilized. Pre- and Post-test data were utilized from college students attending the Marietta College McDonough Leadership Program from their freshman through their senior years. In addition, demographic information will take into account a student's gender, race, major, and the type of experiential opportunity (community service project, study abroad trip, or internship) they experienced as a requirement of the McDonough Leadership program.

\section{Limitations}

Several limitations of the study exist. One key limitation noted was there was a small sample size of participants in the study. In addition, the researcher only used pretest and post-test data from students within the McDonough Leadership program. Additional research suggested would include using a control group of students who did not participate in the McDonough Leadership program to determine if leadership skills were developed at an equivalent rate according to the SLPI - Self and SLPI - Observer.

\section{Organization of the Study}

The remainder of the study is organized into five chapters. Chapter Two presents a review of the relevant literature dealing with leadership, leadership development, and experiential learning. Chapter Three delineates the research design and methodology of the study including the instruments used to gather the data, the procedures followed, and the determination of the sample selected for study. An analysis of the data and a discussion of the findings are presented in Chapter Four. 
Chapter Five contains the summary, conclusions, and recommendations of the study. The study concludes with a bibliography and appendices containing relevant cover letters and instruments used. 


\section{Chapter Two}

\section{Literature Review}

James M. Burns in his seminal book Leadership, said "leadership is one of the most observed and least understood phenomena on earth" (Burns, 1978, p. 2). This review of leadership and other concepts relevant to this study, gives administrators a greater understanding of what is known about leadership and what still needs to be learned.

The literature review is divided into four sections. The first section will review the major leadership theories and how these theories have changed over time. The second section discusses leadership development among college students. This section also describes undergraduate leadership programs and the literature on teaching leadership. The third section focuses on research studies pertaining to experiential learning and its growth in developing leadership knowledge and skills. The fourth section describes the leadership efforts of Marietta College's McDonough Leadership program, including its mission, history, and program requirements.

\section{Literature on Leadership}

Much of what was written about leadership prior to the $20^{\text {th }}$ century was "based upon observation, commentary, and moralization" (Hackman \& Johnson, 2004, p. 64). Over the past 100 years four primary approaches for understanding and explaining leadership have evolved. This section of the literature review describes key leadership theories and concepts including: the traits approach, the situational approach, the functional approach, and the transformational approach. In addition, the review covers 
the contemporary concepts of power and influence, servant leadership, and transformational leadership.

\section{Traits Approach}

In the early twentieth century, it was widely believed that leaders possessed

unique characteristics with which they were born. Also known as the "great man theory" it suggested that individuals were predisposed to these psychological and physiological characteristics - one was either born with them or not (Hackman \& Johnson, 2004).

Early studies like Thomas Carlyle's Heroes and Hero Worship emphasized the physical characteristics of leaders (Hackman \& Johnson, 2004). They focused on factors such as height, weight, appearance, intelligence, and disposition. Other studies like Francis Galton's Hereditary Genius examined status, social skill, mobility, popularity and other social traits in order to determine which characteristics were most closely associated with effective leadership (Hackman \& Johnson, 2004).

In 1948 a published review of 124 studies examined leadership and the traits and personal factors related to leadership. This review found that effective leadership was based more upon an individual's characteristics rather than the possession of a combination of traits (Stodgill, R.M., 1948). In a later review of 163 trait studies, Stodgill remained convinced that personality traits alone did not determine who could and could not lead. He believed that both traits and situational factors influenced leadership (Stodgill, 1974).

More recent research, utilizing advanced statistical techniques, has suggested that certain personal characteristics play a role in the perception of a leader. Therefore 
traits cannot solely predict leadership effectiveness, only the perception that someone can lead (Kenny, \& Zaccaro, 1983).

The concept that you are either born a leader or not, has never been adequately supported by research. While certain traits can be advantageous to possess, personal traits alone cannot ensure the effectiveness of a leader. Some competencies which have been determined to help differentiate successful leaders from their counterparts include: intelligence, self-confidence, determination, integrity, and sociability (Northouse, 2007).

\section{The Situational Approach}

As trait leadership became less accepted, theorists looked for new explanations of leadership behaviors. Many researchers began to pursue contingency or situational leadership for explaining the role a leader's behavior plays in any given situation (Burns, \& Stalker, 1961).

One of the most cited situational models is Fiedler's contingency model of leadership (1967). Fiedler's model suggested the effectiveness of a leader is determined by the amount of influence a leader has over their followers. The factors that determine a leader's influence include position power, task structure, and interpersonal relationships between leaders and group members (Fiedler, 1967).

A leader's power is determined by his or her position in the group and relates to a leader's ability to reward or punish followers. The ability for a leader to effectively lead can also be determined by whether or not a task is structured or unstructured. Structured tasks are easier for leaders to evaluate since they have very specific procedures and agreed upon outcomes. Unstructured tasks can be accomplished in a 
number of ways, making it more challenging for leaders to determine the best method of task completion. The relationship between a leader and his or her followers is a factor in the influence a leader has over followers. A good relationship is characterized by loyalty and respect, while a poor relationship results in lower motivation and commitment (Fiedler, 1967).

Path-Goal Theory is also characterized as a situational approach to leadership. It is based upon expectancy theory which claims that followers are more motivated if they believe that the successful completion of a task provides a path to a goal they value. A leader plays a significant role in influencing follower perception of task paths and goal desirability (House, \& Mitchell, 1974).

The ability to motivate followers is influenced by a leader's communication style and situational variables. Communication styles noted by Robert House and Terrence Mitchell (1974) include directive, supportive, participative, and achievement-oriented leadership. Situational factors which help determine the selection of a leadership communication style is the nature of the follower's needs, abilities, values and personality and the nature of a tasks structure and clarity. House and Mitchell (1974) hypothesized that a leader must determine the appropriate communication style to be used to enhance a follower's motivation and satisfaction dependent upon whether a task is structured or unstructured and the followers' skill, experience, and confidence.

Hersey and Blanchard's situational leadership theory, similar to the Fiedler Model and Path-Goal Theory divide leader behaviors into task and relationship considerations. In addition, this approach takes into consideration a follower's maturity level as it relates 
to task related skills, abilities, and knowledge and the followers confidence, willingness and motivation (Hersey \& Blanchard, 1996).

According to situational leadership theory the maturity level of the follower will dictate the appropriate response by the leader. A leader may utilize a delegating, participating, selling, and telling strategy depending upon the follower's readiness level. By engaging in appropriate leadership behavior a leader can influence follower behavior and facilitate growth and development. The more effective a leader is at determining a follower's readiness level, the more efficient a leader can be when choosing the appropriate situational response.

Leader-member exchange (LMX) theory describes how leaders can develop relationships with their followers. The theory focuses on the coordination of actions between leaders and followers in order to accomplish a mutual goal (Graen \& Cashman, 1975). George Graen (1976) suggested that this coordinated effort is done through the roles that the leaders and followers play. Leaders generally establish two groups of followers, the in-group and out-group. The relationship with in-group members is characterized by high levels of trust, mutual influence, and support. Authoritarian and task oriented leadership communication is more evident in the relationship between out-group members and their leader (Hackman, \& Johnson, 2004).

\section{Functional Group Approach}

As the $20^{\text {th }}$ century progressed, theorists began to distinguish between leadership characteristics and behavior. While the trait and situational approaches to leadership focused on individual characteristics of leaders and followers, the functional group approach looks at the communicative behavior of leaders. The functional 
approach hypothesizes that the ability to communicate as a leader is what determines leadership.

Kenneth Benne and Paul Sheats (1948) looked at the concept of functional leadership as it relates to team development. They identified three types of group roles. Task related roles include: the initiator, opinion seeker, opinion giver, the elaborator, the coordinator, and the energizer. Group building and maintenance roles contribute to the development of open and healthy relationships among team membership. Individual roles can serve as obstacles to effective team building and effectiveness (Benne \&Sheats, 1948). The functional approach can provide a guideline for leaders by suggesting functions that a leader may perform to develop team leadership (Hackman \& Johnson, 2004).

\section{Transformational Leadership}

Beginning in the late 1970's, the transformational approach emerged to explain the role of leadership. James MacGregor Burns (1978) hypothesized that traditional leadership was designed to satisfy basic human needs. He labeled these approaches as transactional leadership. He proposed a more complex and potent approach which he referred to as Transformational leadership.

Transformational leadership is intent on meeting the self-esteem and selfactualization needs of the group. Burns (1978) found that leaders were either transformational or transactional. Other experts believed that leaders became transformational after they met the physiological, safety and belonging needs served by a transactional approach to leadership (Bass, 1985; 1990; Bass \& Avolio, 1994). Bernard Bass explains "unlike the transactional leader who indicates how current needs 
of followers can be fulfilled, the transformational leader sharply arouses or alters the strengths of needs that may have lain dormant" (Hackman \& Johnson, 2004, p. 90).

Other researchers have attempted to describe the characteristics of transformational leaders. Characteristics commonly associated with transformational leaders include: Creativity, interactive, visionary, empowering, passionate, and charismatic (Peters \& Waterman, 1982; Peters \& Austin, 1985; Peters, 1992; Bennis \& Nanus, 1997; Kouzes\& Posner, 1995; Neff \& Citrin, 1999; Avolio, \& Bass, 2002.)

\section{Power and Influence}

Hackman and Johnson (2004, p. 90) suggest that "exercising influence is the essence of leadership". While leadership theory has continued to evolve over the last century, the concept of power and influence has held strong. Much research has been done about the sources and use of power, and its relationship to the modification of behaviors through influence.

In one survey done of managers from North America, Mexico, Asia, Europe, and Australia the most common answer to the question "what are the characteristics they most admire in their leader" was credibility. Credibility is considered the foundation for successful influence since it is the reason an influence strategy either succeeds or fails (Kouzes\& Posner, 1993).

The concept of credibility has been central to the study of leadership since ancient Greece. Ancient Greeks studied the communication of leaders and used the term "Ethos", meaning credibility, to define high moral standards, intelligence, and character. More recently researchers have discovered the dimensions of credibility 
include competence, trustworthiness, and dynamism which refer to a leader's confidence, activity, and assertiveness (Brembeck \& Howell, 1951).

Gary Yukl (1995) and his associates identified the key strategies for achieving influence. The nine influence tactics include: rational persuasion, inspirational appeals, consultation, exchange tactics, personal appeals, ingratiation, legitimating tactics, pressure tactics, and coalition tactics. If a leader has built credibility, the use of these strategies will be more likely to succeed (Yukl, Guinan, \& Sottolano, 1995). Hackman and Johnson (2004), however, suggest that when leaders must influence those who actively disagree with them, "the use of argumentation and negotiation may be necessary" (p. 90).

Influence is often dependent upon the use or misuse of a leader's power. Leaders can only bring about change if they utilize power to enlist supporters, overcome resistance, collect resources and create alliances. Leadership experts Warren Bennis and Burt Nanus (1985) noted that "power is the capacity to translate intention into reality and sustain it. Leadership is the wise use of this power" (pp. 17-18).

If power is the currency of leaders, than understanding the sources of this power becomes essential. Most experts acknowledge power comes from five sources including coercive power or the ability to administer punishment. Secondly leaders have the ability to reward followers for their support by delivering something of value to them. Leaders may also have legitimate power which resides in their position or title. Expert power is based upon the person and not the position, with the leader influencing group members because of his or her knowledge and expertise. Finally referent power 
is based upon a follower's admiration of a leader and a leader's ability to serve as a role model. (Hackman, \& Johnson, 2004).

\section{Servant Leadership}

Contemporary leaders have begun to follow a paradoxical approach to leadership called servant leadership. Its popularity has grown in recent years because of its altruistic ethical overtones (Block, 1993; De Pree, 1989, 1992). Servant leadership emphasizes that leaders should be attentive to their followers needs and must empathize with their situation. Robert Greenleaf (1977), considered the father of servant leadership, argued that leadership was given to someone who by nature serves others. He went on to describe the process of an emerging leader as a servant who helps others become more knowledgeable, more autonomous, and eventually more like a servant themselves.

The servant leader not only has a responsibility to the group, but also a social responsibility to society. Where inequalities and social injustices exist, the servant leader finds a way to remove them and make everyone better. Servant leaders do not use traditional forms of institutional power, but instead shift authority and control to those who are being led. The power is within the community because it is within the group of individuals to respect, trust, and feel passionate about (Graham, 1991).

Other experts have taken Greenleaf's concept of Servant Leadership and expanded it to include ethical leadership. Ronald Heifetz (1994) formulated a unique approach of ethical leadership by focusing on the values of individuals and organizations. Leadership he surmised is the use of authority to assist followers and organizations in dealing with conflicting values that emerge in society and the 
workplace. The leader develops an environment of trust, nurturing, and empathy to help mobilize people to confront the difficult issues and struggle with change and personal growth (Heifetz, 1994).

Leadership experts have also suggested that morality and moral responsibility are key components of ethical or servant leadership. A leader's responsibility is the role it plays in the moral development of his or her followers (Bass \& Steidlmeier, 1999). The leader must help followers assess their own values and stress the values of liberty, justice and equality (Ciulla, 1998).

\section{The Leadership Challenge}

As leadership theory progressed, some experts were interested in studying why leaders succeed. One model was developed after interviewing over 1,300 middle and senior level managers to find out what are the fundamental practices that allow leaders to get extraordinary things accomplished.

The model developed by James Kouzes and Barry Posner (1987), helps differentiate leaders from managers. According to Kouzes and Posner, "when we think of leaders we recall times of turbulence, conflict, innovation, and change; however, when we think of managers, we recall times of stability, harmony, maintenance, and constancy" (2002, p. 31-32). Chapter 3, discusses the Leadership Challenge further, since it is the basis of the Student Leadership Practices Inventory (SLPI), which is the instrument being used for this research study.

The Leadership Challenge consists of five fundamental practices. The first component of this framework is, Challenging the Process, or being willing to change the status quo and innovate, grow and improve. The second dimension, Inspiring a Shared 
Vision is about leaders creating a compelling vision that can guide people's behaviors. Effective leaders have the ability to work with others, build trust, and promote collaboration which constitutes the third dimension Enabling Others to Act. The fourth leadership practice is Modeling the Way and focuses on leaders being clear about their own values and philosophies. Finally, leaders Encourage the Heart by recognizing the effort of their followers and rewarding them for their accomplishments (Kouzes, \& Posner, 2002).

\section{Leadership Development}

College administrators are being asked to not only develop new leadership initiatives, but increasingly are asked to show the efficacy of these programs. Unfortunately, many leadership development initiatives utilize models of business practices developed in corporate America (Wilcox, 2004). According to Kouzes and Posner (2002), "serious questions can be raised about whether such (business) models and their concomitant instruments are applicable to college students and collegiate environments, which differ considerably from the environments in which managers operate" (p. 4).

Little is stated in the literature about how leadership behaviors are developed through college leadership programs. Instead, much of the research is on traditional paradigms which focus on skill attainment and acquiring power and influence over followers (Wilcox, 2004).

Contemporary models of leadership development have begun to focus on empowerment, acquisition of transformational skills, and the creation of collaborative vision (Lussier \& Achua, 2001). This new paradigm has led leadership development 
programs to emphasize the process of leadership and the relationship between leader and follower.

The growth of leadership development programs at colleges and universities has occurred because the importance of developing leadership skills continues to be acknowledged by college administrators and emphasized in institutional mission statements (Bass, 1991). Karnes and Stephens (1999) suggest "the ability to make leadership-based decisions continues to grow in importance as society progresses toward the next century" (p. 62).

The literature on leadership development has shown only a small sampling of suggested models for the development of leadership among college students. However, the Council for the Advancement of Standards in Higher Education (CAS) has developed universal standards for the development of leadership skills for college students. CAS has modified the traditional concepts of leadership to reflect a shift in leadership theory to "an inherently relational process of working with others to accomplish a goal or to promote change" (Council for the Advancement of Standards in Higher Education, 2006, p. 3).

Leadership as a relational process incorporates the following four elements: 1) inclusion, 2) empowerment, 3) purposefulness, and 4) ethical practices as well as the overall process orientation (Council for the Advancement of Standards in Higher Education, 2006). The literature has described these elements as working together to accomplish change or make a difference to benefit the common good (Komives, Lucas, \& McMahon, 1998). 
The components established by CAS which demonstrate successful leadership include 1) the development of self-awareness and the ability to understand others; 2) the ability to recognize diverse perspectives; 3 ) the ability to recognize the need for change in organizations; 4) the establishment of purpose; 5) the ability to work collaboratively; and 6) the awareness of conflict management techniques.

In addition to the CAS standards, Cherrey and Isgar (1998) suggest that the key elements of leadership development include: 1) understanding the diversity and complexity of interrelated organizational systems; 2) reflecting critically and continuously, and learning with a commitment to the betterment of society; 3) valuing individual differences and embracing inclusiveness; and 4) practicing collaboration.

The literature clearly acknowledges the importance of leadership development among college students. The W.K. Kellogg Foundation, for example, continues to fund leadership efforts at colleges and universities because it believes: 1) our society needs more and better leaders, 2) effective leadership skills can be taught, and 3) the college environment is a strategic setting for learning these skills and theories (Astin \& Cress, 1998; W.K. Kellogg Foundation, 1999).

The CAS standards have suggested that effective leadership development programs have three key elements. They must be comprehensive in nature and key components of Student Leadership Programs (SLP) must include the following: "opportunities for students to develop the competencies required for effective leadership; multiple delivery formats, strategies, and contexts; and collaboration with campus and community partners" (Council for the Advancement of Standards in Higher Education, 2006, p. 7). 


\section{Undergraduate Leadership Programs}

Little empirical research exists about the effectiveness of undergraduate leadership programs like Marietta College's McDonough Leadership Program. One study by Connaughton, Lawrence, \& Ruben (2003) examined the efficacy of an undergraduate leadership program at Rutgers University. The authors performed a case study analysis of Rutgers' Student Leadership Development Institute. Connaughton et al. (2003) noted that "citizens must become better educated to fulfill leadership challenges responsibly, effectively, and ethically" (p.47). The authors noted through their research that "leadership competencies are best developed over time through a program that fosters personalized integration of theory and practice and that conceives of leadership development as a recursive and reflective process" (p. 46).

Connaughton et al. (2003) identified nine principles that serve as the foundation for the Student Leadership Development Institute. The authors conclude that there are nine principles that can be used as a basis for the development of student leaders through undergraduate leadership programs. The first is, leadership is complex; second, leadership is focused on the interests of others; third, leadership is interactive and dynamic; fourth, leadership is contextual; fifth, leadership is considered emergent and individuals in low-level positions often emerge as effective leaders; sixth, leadership is both a science and an art; seventh, leadership occurs through effective communication; eighth, leadership is increasingly "virtual" in nature and communication skills must be effective in the virtual world as well as in the face-to-face world; and ninth, leadership can be learned and taught (Connaughton, 2003) 
Although leadership is not a static trait, it can be taught and has a place in academia (Scott, 2007). Connaughton et al. (2003) continued by suggesting that leadership education should be taught across multiple disciplines, which is evident in the nine principles that they identified. In addition, Bass (1991) reflected on the structure of an effective undergraduate program of leadership. Bass suggested that an undergraduate leadership program should be comprised of social-psychology classes and business/management classes, with an underlying emphasis on liberal arts education.

Prince (2001) outlined four methods from which students should develop the essential skills of a leader. First, the faculty's teaching methods should match the desired outcomes they hope to achieve. Second, learning opportunities must be created to allow students to apply their knowledge and to experience the consequences of their actions. Third, the students should be strongly encouraged to reflect upon their leadership experiences with faculty members and peers. Lastly, students should have a vicarious and active learning experience.

In their writings about the University of Richmond, the first undergraduate leadership program in the United States, Morrill and Roush (1991), suggested that leadership education not only benefits the students by providing an integrated curriculum, but also improves higher education by providing coherence to the undergraduate curriculum. Scott (2007) suggested that leadership education is neither passive nor based only in lectures. Rather, Morrill and Roush (1991) believe that students should be actively and personally involved in the learning experiences. 
Leadership Development should integrate and emphasize experiential and active components throughout their curriculum.

Other research done on the efficacy of undergraduate leadership programs suggested that action is the key component to leadership development. McNally, Gerras, and Bullis (1996) reflected on the leadership program at the U.S. Military Academy at West Point. At the Military Academy, students are required to "identify what is happening, account for what is happening, and then formulate and apply leader actions" (McNally et al., 1996, p. 177). Leadership requires an awareness of the situation and an ability to apply the leadership skills necessary to implement the appropriate action.

The literature is consistent in suggesting the need for multi-disciplinary education throughout an undergraduate leadership program. Leadership cannot be taught through business/management theories alone, nor can it only be grounded in the behavioral and psychological fields (Bass, 1991; Burns, 1978; Gardner, 1990). The multidisciplinary aspect of a liberal arts education is the foundation for many of the leadership skills that are taught in leadership programs (Bass, 1991; Brown, 1994, Scott, 2007).

This emphasis on multidisciplinary education in leadership development programs should include teaching students in a setting where many disciplines are represented. Students should have the underlying classroom theory, the opportunity to practice those skills, and the chance to evaluate and reflect upon their experiences (Scott, 2007). 
Undergraduate leadership programs should also emphasize the relational aspect of leadership. Bass (1991) and Gardner (1990) argue that the emphasis on relationships is what elevates leadership from an absolute science to a social science. Relationships with followers and the ability to persuade them toward common goals are essential to a leaders' effectiveness (Bass, 1991; Burns, 1978; Gardner, 1990; Scott, 2007). McClelland and Burnham (1976), Burns (1978), Gardner (1990), and Bass (1990) also argue that the relationships must be deep yet professional. The work by Hutt (2007) accentuates the need for leadership-follower relationships to be transformational and significant, while being intimately connected to be effective.

The literature also suggested that undergraduate leadership programs should teach conflict management as part of its curriculum. Leaders often deal with conflict and therefore must view conflict with a multi-faceted lens (Bass, 1990). Bass (1990) and Burns $(1978,2003)$ argued that transformational leaders more effectively deal with conflict. Referring back to a classic management model of strengths, weaknesses, opportunities, and threats, or a SWOT analysis (Hazelbaker, 2006); an effective leader must be able to embrace threats and weaknesses in order to advance the organization (Bass, 1990).

Other literature suggested that one of the objectives of undergraduate leadership programs is the development of citizen leaders (Connaughton, et al., 2003; McNally, et al., 1996; Morrill \& Roush, 1991; Scott, 2007). The importance of developing students as citizen leaders is reinforced by a study conducted by the Kellogg Foundation (Zimmerman-Oster \& Burkhardt, 2001) that assessed individual outcomes of students in some undergraduate leadership programs. This study concluded that "90 percent of 
leadership programs surveyed reported that their participants had an increased sense of social, civic, and political awareness" (Zimmerman-Oster \& Burkhardt, 2001, p. 6).

Some authors have suggested the reason that there are not more undergraduate leadership programs is that as Burns suggested "leadership is not a familiar concept in terms of what colleges and universities do" (Jones, Lucas, \& NCLP Staff, p. 1).

This may be one reason why many colleges have chosen to add singular courses to a curriculum rather than develop a freestanding program (Scott, 2007).

A survey of 3,000 colleges and universities demonstrated that nearly 600 colleges and universities had leadership offerings ranging from short one and two hour workshops to full bachelor and master degree options yet only $3 \%$ of respondents had a major or a minor (Howe \& Freeman, 1997). Further study of leadership programs in the Midwest showed similar results in that leadership was part of program rather than a program unto itself (Scott, 2007).

Research has also show that there is an increasing popularity of leadership courses within certain academic disciplines. One study revealed 135 disciplineintegrated leadership programs, which clearly demonstrates the recognition by higher education of the value of leadership training. However, it also suggested a lack of commitment to freestanding programs. The implication is that colleges and universities recognize the value of leadership, but it is not valued enough to make a full commitment (Scott, 2007).

Scott (2007) has suggested that this may be a result of the fact that there are no clear-cut best practices related to the teaching of effective leadership in an undergraduate setting. Connaughton, et al. (2003), Morrill and Roush (1991), and Bass 
(1991) effectively demonstrate the need for leadership programs in an undergraduate setting. These articles also allude to the fact that, as Morrill and Roush stated, "The programs are at the margin of institutional life" (p. 26).

\section{Teaching Leadership}

While the importance of leadership is acknowledged, some experts have questioned whether or not leadership can be taught through leadership training courses. The Institute of Leadership has suggested that there is a tendency in society to look for the quick fix (Owen, Hodgson, \& Gazzard, 2004). Leadership development is a lifelong process that cannot be accomplished through a training regimen alone. While leadership skills can be acquired through training and practiced through relevant experiences, the process must be ongoing. Leadership is as much about who we are, as what we do or how we do it. John Maxwell suggested leadership development is about maximizing our potential to influence others (1993).

One of the challenges in developing undergraduate leadership programs is the question of how best to teach leadership. Some institutions have chosen to develop leadership skills in students through extra-curricular offerings, while others have taught leadership through curricula programs. Research done by the Center for Creative Leadership (CCL) and the Jepson School of Leadership has shown that the majority of offerings in leadership education is for credit and is offered through academic departments (Scott, 1997).

One school of thought is that leadership is in everyone, and those skills or traits of effective leaders are drawn out only by engaging students in situations or experiences where these skills or traits can be brought out (Scott, 2007). The literature 
suggested this can only be done with effective teaching methods that promote selfdiscovery (Bass, 1990; Burns, 1978, 2003; Doh, 2003; Gardner, 1990).

However, some authors suggested that leadership cannot be taught (Gunn, 2000). Gunn points out that leadership development appears to be situational and that many people are not emotionally mature enough to examine themselves as thoroughly as leadership programs require. Students, Gunn suggested, should develop themselves as whole persons over their life time (2000). It is through one's life, Gunn argued, that the innate abilities necessary to be effective leaders emerge contingent upon situations that are presented to individuals.

Others suggest that while everyone possesses some innate ability to be a leader, the skills and behaviors necessary to be an effective leader can be taught and improved (Scott, 2007). Socrates for example, was both leader and an educator of future leaders (Adair, 1989). Indeed the Socratic method of teaching is one in which a student's question is turned back to the student for introspection and self-discovery, and is valuable in the teaching of leadership through undergraduate leadership programs (Goleman, Boyatzis, \& McKee, 2002).

Fortunately, the argument that leadership cannot be taught is refuted by the literature. In interviews with leading business and management faculty conducted by Doh (2003) those interviewed presented arguments on why leadership can indeed be learned. Although the interviewees varied in their perspectives of how it can be taught and where it should be taught all agreed that leadership can be taught and learned at the undergraduate level (Doh, 2003). 
Clearly, determining whether or not leadership can be taught is as complex as trying to define leadership itself (Bass, 1990; Stogdill, 1974; Yukl, 1989).If the premise that leadership can be taught is accepted as true, in what ways should colleges and universities go about teaching leadership? As mentioned earlier, a review of the literature suggested that any leadership teachings, whether a singular course or an entire program, fit best within an interdisciplinary setting (Bass, 1990; Burns, 1978; Gardner, 1990).

Leadership education cannot successfully be performed as a singular course with no other support from courses in other disciplines (Scott, 2007). Milter and Stinson (1995) argued that the education of leaders should be holistic and integrated, rather than a piecemeal approach that is isolated. Similarly, Nirenberg (2003) argued that "the orthodoxy of limiting learning from a single discipline taught entirely within a single school is unacceptable" (p. 7). Nirenberg and others (Bass, 1990; Gardner, 1990) made it clear that the effective teaching of leadership cannot exist in a silo of any one discipline. Rather, the skills required to be effective leaders are not limited to singular disciplines (Scott, 2007).

Nancy Huber (2003) argued that flexible thinking and a tolerance for ambiguity are important elements of creativity and allow for leaders to have different perspectives than if they learned in a narrowly focused program. Regarding the teaching of leadership, Goleman, et. al. (2002) suggested that effective leaders do not learn or work by just one leadership style.

While some have suggested that teaching leadership is about influencing others (Hornyak \& Page, 2004), research suggested that leadership development is about 
helping individuals discover their own paths and merging both organizational and personal goals (Bass, 1990; Burns, 1978; Gardner, 1990).

Another key area of interest in the teaching of leadership is critical thinking and its link to effective management and leadership (Bass, 1990; Gardner, 1990). A survey commissioned by the Kellogg Foundation (Zimmerman-Oster \& Burkhardt, 2001) identifies problem solving as a skill that individuals have acquired at the end of their leadership education. Connaughton, et al. (2003) and McNally et al. (1996) have also discussed the need for effective leaders to be able to analyze situations and think critically and creatively to solve them.

Macpherson (1999) wrote about the need for undergraduate programs to teach students the skills needed to acquire critical thinking skills and become creative problem solvers. Macpherson (1999) illustrated that effective critical thinking requires skills of self-assessment in order to analyze the problem, reflect on the leader's abilities, and create an action plan. Huber (2003) wrote about the tolerance for ambiguity as a key element in leadership. Similarly, Clifford, Boufal, and Kurtz (2004) in an article on critical thinking skill assessment of college students, revealed that both cognitive abilities and personality traits played a role in the critical thinking abilities of students.

The argument that leadership skills are soft and unnecessary for effective leadership teaching (Nirenberg, 2003) appears shortsighted given the literature to support soft-skill implementation into effective leadership education (Bass, 1991). People are relational and lead most effectively, and followers respond more positively, when relationships are an integral part of the experience (Bass, 1991; Burns, 1978, 2003; Gardner, 1990; Goleman et al., 2002; Scott, 2007). 


\section{Experiential Learning}

Experiential learning is a valuable tool in effectively developing student leaders and teaching the principles of leadership. According to CAS standards, it is essential that Student Leadership Program's provide student's opportunities to practice leadership, collaborate with others, and utilize multiple methods of teaching (Council for the Advancement of Standards in Higher Education, 2006). The concept of experiential learning possesses each of these characteristics. The literature recognizes the importance experiential learning plays in leadership development (Miller, 1997).

The teaching of leadership in colleges and universities has included both in and out -of-class experiences. While leadership concepts such as leadership style and skills are best taught through in-class teachings (Northouse, 2009), the development of these skills can best be achieved through the power and potential of experiential learning (Higgins, 2009).

The early development of experiential education began through John Dewey's Experience and Education (1938). John Dewey believed that at the core of active learning individuals must shift from the slavery of blind desires, to the ability to regulate oneself (Jones \& Pfieffer, 1980).

The terms experiential learning and experiential education are often used interchangeably to define an implicit trust in the learner's ability to learn through experience (Higgins, 2009). This concept was first recognized by Kurt Hahn and John Dewey. Kurt Hahn, who helped found Outward Bound and the Association for 
Experiential learning, became fascinated with the educational philosophy of Dr. Cecil Reddie, a radical Scottish headmaster. Reddie's philosophy which was derived from the concepts first authored by Sir Patrick Geddes, involved "educating through the 3 H's - Heart, Hand, and Head rather than the three R's - Reading, wRiting, and aRithmetic" (Higgins, 2009, p. 46). Kurt Hahn began to describe experiential education as learning based upon affective, physical, and intellectual development (Jones\& Pfieffer, 1980).

Kurt Hahn took Dewey's concept of experiential education and active learning further through his creation of the Outward Bound program. Hahn believed that utilizing the outdoors, institutions can challenge students to increase growth and development. The process of adventure and wilderness challenge programs like Outward Bound and NOLS included a cyclical learning cycle where the learner passes through the process of experience, reflection, and application (Sutton, 2002).

The power of experiential learning is the ability for human beings to develop as individuals and discover the world we live in while being guided by our senses. However, Dewey recognized that there are limits to what one can learn experientially (Dewey, 1997). The complexities of the world help limit the scope of what can be learned experientially. The purpose of experiential learning is to affect the learner in three ways: 1) The learner's cognitive structures are altered, 2) The learner's attitudes are modified, and 3) The learner's repertoire of behavioral skills is expanded (Jones, \& Pfieffer, 1980).

These elements of experiential learning are interconnected and change as a whole, not separately. Working on one element, without the benefit of the other two, will be ineffective. 
Lewin (1935) suggested that experiential learning is a never ending process. An action theory must first be formulated based upon our past experiences. A theory is first tested through our behavior and then consequences are assessed, feedback obtained and reflected upon in order to modify and refine our original theory (Lewin, 1935). This theory of experiential learning, according to Kurt Lewin, was based upon twelve principles (Lewin \& Grabbe, 1945). Each principle is relevant to the process of developing as a leader.

Principle One stated that effective learning affects the learner's cognitive structures, attitudes, values, perceptions and behavioral patterns. A learner must learn to become a more effective decision maker. Principle Two is that people believe more in knowledge when they discover it themselves than in knowledge presented by others. This approach to learning based upon inquiry and discovery has been found to increase a student's interest and motivation in learning. Principle Three is that learning is more effective when it is an active rather than a passive process.

Principle Four is the acceptance of new action theories, attitudes, and behavioral patterns and cannot be brought about by a piecemeal approach. Instead, one's whole cognitive-affective behavioral system has to change. Principle Five is that it takes more than information to change action theories, attitudes, and behavioral patterns. This is related to Principle Six that it takes more than firsthand experience to generate valid knowledge; besides experience an individual needs a theoretical system that the experience attempts to prove or disprove.

Principle Seven is behavior changes are temporary unless the action theories and attitudes underlying them change. Principle Eight surmises that changes in 
perceptions of one's self and one's environment are necessary before action theories, behaviors and attitudes can be transformed. Principle Nine is the more caring and supportive the environment, the more likely someone is to experiment with new behaviors, attitudes, and action theories. Principle Ten is in order for change to be permanent, both the person and the environment must change. Principle Eleven states that it is easier for change to occur in a group context rather than by oneself. Lastly, Principle Twelve is that a person accepts a new system of theories, attitudes, and behavioral patterns when he or she enters into a new group (Lewin \& Grabbe, 1945).

These principles are essential in the process of developing leaders. Faculty and student affairs professionals are known to be more effective at teaching, training, and developing leaders through active learning and experiential education (Miller, 1997).

\section{Marietta College}

Marietta College is one of Ohio's oldest continually operating institutions of higher education (Ohio History Central, 2010). Marietta College is a private, coeducational, nonsectarian, undergraduate, residential, contemporary liberal arts college founded in 1835. One of America's 37 "Revolutionary Colleges," institutions with origins reaching back to the 18th century when it was originally founded as the Muskingum Academy in 1797 (Marietta College, 2011).

In 1830, the Reverend Luther Bingham established the Institute for Education in an effort to educate others regarding the values and beliefs of his Congregationalist Church. The Institute for Education failed financially in 1832; however, local citizens in Marietta created the Marietta Collegiate Institute and Western Teachers' Seminary, a 
non-denominational institution. In 1835 , this college changed its name to Marietta College (Ohio History Central, 2010).

At first, Marietta College included both a preparatory school as well as a traditional college. The institution grew quickly and in 1846, sixty undergraduates and 117 preparatory students attended the school (Ohio History Central, 2010).

Throughout its history, Marietta College has emphasized a commitment to a liberal arts education. The institution has desired to create a well-rounded student, knowledgeable in a wide variety of subjects. In 2005 , Marietta College began to offer both undergraduate and graduate degrees. The school currently boasts an enrollment of more than 1,300 full-time students (Marietta College, 2011).

Marietta College offers 42 majors along with a large number of minors, all of which are grounded in a strong liberal arts foundation. Marietta College is known for its petroleum engineering, athletic training, and physician assistant majors as well as its McDonough Leadership program and its highly successful China Program (Marietta College, 2011).

The athletic department sponsors 18 varsity sports that compete in NCAA Division III and the Ohio Athletic Conference. The college's baseball team won the fifth Division III College World Series Championship in school history in 2011. The college also sponsors an intramural and recreation program, which are housed in the Dyson Baudo Recreation Center (Marietta College, 2011).

The majority of the students which attend Marietta College are from Ohio, Pennsylvania and West Virginia; however a sizable portion of the student population is from the New England states, and Asia (Marietta College, 2011). 
Marietta College provides a strong foundation for a lifetime of leadership, critical thinking, and problem solving. Marietta College offers undergraduates a contemporary liberal arts education and graduate students an education grounded in advanced knowledge and professional practice. Intellectual and creative excellence defines the Marietta experience (Marietta College, 2011).

Students at Marietta College, as part of the institutions core curriculum, are provided opportunities to study many fields in breadth, which complements the in-depth study required by a major field. Each student is required, therefore, to acquire a breadth of knowledge across the areas of historical perspective, scientific inquiry, social analysis, quantitative reasoning, fine arts, literature, global issues and diversity, leadership and ethics, and courses which emphasize a writing intensive curriculum (Marietta College, 2011).

The 2009 Forbes America's Best Colleges Ranking ranked Marietta 112th Best out of roughly 4000 undergraduate institutions in The United States, 56 spots up from the previous year. According to this ranking Marietta is the 4th best College (after Kenyon College, College of Wooster, and Oberlin College) in the state of Ohio. Forbes also placed Marietta College ahead of Johns Hopkins University (173), University of Michigan (200), and Cornell University (207) on the basis of student satisfaction, indicator's of post-graduation success, likelihood of graduation from college within four years, and debt levels after graduation (Ask.Com, 2010).

The 2010 U.S. News \& World Report Best Colleges ranked Marietta 6th in the Baccalaureate Colleges in the Midwest category. The school was tied with Cedarville University and Huntington University (Ask.Com, 2010). 


\section{The McDonough Leadership Program}

The McDonough Center for Leadership and Business at Marietta College started in 1986 with a $\$ 5.5$ million gift from the Bernard P. McDonough family (Schwartz, 1994). Steven Schwartz (1994) suggested that the center was not received with the kind of enthusiasm the institutions leadership anticipated. The faculty at the liberal arts institution was somewhat reluctant to start a center that was inextricably linked to something as vocational as business (Scott, 2007).

Many faculty believed that the practice of teaching leadership was a fruitless enterprise since effective leaders, they thought, were "born, not made" (Schwartz, 1994). The McDonough Leadership Program opened its doors to 28 students in 1987. At this time students could only pursue a Certificate in Leadership Studies. The center was completed and dedicated in 1988. In 1989-1990 the first leadership classes were offered in the McDonough Center for Leadership and Business (Schwartz, 1994).

Schwartz suggested that throughout the process to begin the leadership program and to design the McDonough Center, the College president and the Board of Trustees ensured the involvement of many constituencies (1994). The administration developed a faculty advisory committee that helped advise the president on faculty concerns related to the center. They also enlisted community and student input into the leadership program's design (Scott, 2007). One of the interesting developments which came out of this advisory committee was that the students believed that the leadership education should be available to all students and not just an elite few (Schwartz, 1994). 
There were several assumptions that were agreed upon by the Faculty Advisory Committee including that the Center should be owned by the entire campus and the college would not hire separate leadership faculty. This would ensure that the McDonough Leadership Center would observe the spirit of the liberal arts. Faculty also insisted that the leadership program should be offered to incoming freshman, and would emphasize leadership and not leadership in business. It was believed at the time, as research now has reiterated that the program should be multi-disciplinary (Scott, 2007).

All of these original components to the McDonough Leadership Program now remain, except for request of the Advisory Committee that full time leadership faculty not be hired. In fact the first full-time faculty member in Leadership Studies was added in 1999-2000 (Scott, 2007). Now, there are four full-time faculty, yet only one of them currently teaches leadership exclusively.

Students accepted into the leadership program can pursue a Bachelor's Degree in International Leadership Studies, a Minor, or a Certificate in Leadership Studies. In the Fall of 2008, the McDonough Center also launched its Teacher Leadership Certificate (TLC), a new academic program designed for students pursuing careers in education. Each of these degree and certificate offerings exists in a collaborative manner with the other academic programs at Marietta College to strengthen the students' educational experiences (Scott, 2007).

The Center graduated their first class in 1990-1991 with students receiving Certificates in Leadership Studies (Schwartz, 1994). In 1992-1993, the Marietta College faculty approved the creation of a Minor in Leadership Studies, and the first students then graduated in 1994. The McDonough Center for Leadership introduced the major in 
International Leadership Studies with the Marietta College faculty's approval in 20022003 (Perruci, 2007, p. 1) and abides by a "core value of a deep commitment to the development of leaders who are thoughtful and passionately engaged in their communities."

After the major in International Leadership Studies was introduced, the minor and the certificate were changed to add the international focus (Scott, 2007). The first class of International Leadership Studies graduated in 2005-2006 with a total of seven graduates.

The McDonough Faculty Advisory committee (MFAC) developed the core concepts for the McDonough Leadership Program. These core concepts included, one, leadership can be defined in a variety of ways and from a set of abilities to a dynamic process; two, leadership involves not just leaders themselves, but also followers and the situations in which leaders and followers interact; three, leaders and followers interact in power/influence relationships and interventions can be initiated by either the leader or the follower in order to enhance the effectiveness of the interaction; and, four, one's personal approach to leadership must be based on an accurate appraisal of one's strengths and weaknesses as a leader/follower (Schwartz, 1994).

The McDonough Leadership Model was developed to help define the core concepts that McDonough Scholars experience. This model conceptualizes leadership as "a process through which leaders and followers work together toward a common goal within an immediate environment while being influenced by the values of a larger cultural context" (Marietta College, 2011). The McDonough Leadership Model recognizes that leadership is complex and multi-dimensional. It also acknowledges the 
importance the environment and the roles that leaders and followers play and how they are influenced by the societal and cultural values and norms in which they live.

The McDonough Leadership Program also emphasizes the many definitions of leadership and stresses the importance of context in leadership. To ensure these core values and key concepts are a part of the leadership program, the administration developed unique characteristics for the major, the minor, and the certificate of leadership (Scott, 2007).

The curriculum is comprised of three major components: knowledge, action, and growth. Knowledge in the McDonough Leadership Program is attained though the many readings, lectures, and large and small discussion groups that is required. Cutting-edge theories are introduced and debated, and the students are challenged to consider all sides of the latest leadership concepts.

In addition McDonough Leadership Scholars are expected to put their knowledge into practice. This action component of the curriculum included servicelearning initiatives in the community, involvement and development of cutting edge projects, internships, and study abroad trips. Students also actively participate in prestigious leadership conferences and on faculty guided international trips (including Ghana, Guatemala, Belize, China, and Australia). This concept of experiential learning is considered a core component of the McDonough Leadership Program and is what separates it from other leadership programs nationally (Marietta College, 2011).

The growth portion of the McDonough Leadership Program is designed to allow students an opportunity to reflect upon their experiences and measure their development from the time they arrive on campus as freshman through the end of their 
leadership studies at Marietta College. One of the key measuring tools utilized is the SLPI- self and SLPI- observer surveys (used in this research) taken by students their freshman and senior years.

Each degree offering begins with the same sequence of leadership courses (Marietta College, 2011) in the same sequential order. However, the major consists of seven different required leadership courses plus a choice of either one other leadership course or a political science or a communications course. This totals 20 hours in the leadership component and emphasizes a thorough understanding of leadership theory and practice. In addition to the leadership core courses there is also a foreign language component that consists of 15 semester hours in Chinese, French, or Spanish. The foreign language component may be waived if the student is a non-native English speaking student (Marietta College, 2011).

For all students majoring in International Leadership Studies, there is a core of 12 hours of liberal arts courses, including International Politics and History of World Civilizations courses, which are both required (Marietta College, 2010). This is another way the McDonough Leadership Program emphasizes a multi-discipline approach to leadership (Scott, 2007).

Additionally, students are required to select from an area study component. This is a concentration of courses totaling 9 semester hours in a geographic area of interest. Students may choose from Asia, Europe, or Latin America.

Finally, students are required to engage in a semester long experiential learning opportunity. These include an international study abroad experience, community service project, or an internship (Marietta College, 2011). In addition, students are 
required to complete 125 community service hours as part of their major in International Leadership Studies, 100 service hours for students minoring in Leadership Studies, and 50 hours for certificate of leadership studies.

The minor differs from the major in the following ways: there is no language requirement; there is no area study component; and there is no liberal arts core component, although the major that a student has chosen may have a liberal arts core competent as a requirement. There are eight required leadership courses, one more than the major, since in the major the additional leadership course was an option among four courses and in the minor it is required. The experiential learning opportunity is also required for students in the minor. In addition, students are only required to complete 100 hours of service as a minor in Leadership Studies (Marietta College, 2011). The certificate is different from the minor in the following ways: there are only six required leadership courses.

Majors, minors, and certificate students all have an integrated service component, though the amount of service hours vary. In addition, all three types of McDonough scholars require the digital portfolio reflection (Marietta College, 2011).

There is a separate, selective admission policy to the McDonough Leadership Program. Admission to the McDonough Scholars Program (ILS, MLS, CLS, and TLC) is competitive. Students pursuing the ILS major, the minor/certificate in Leadership Studies, as well as the Teacher Leadership Certificate is named McDonough Scholars.

\section{Summary}

The literature review focused on the major leadership theories and how these theories have changed over time. Special emphasis was also placed on understanding 
transformational leadership and the role Kouzes and Posners' (2002) five dimensions of leadership plays in the leadership development among college students.

Through the literature review, an understanding of the theory of experiential learning and its growth in developing leadership knowledge and skills was gained. In addition the knowledge of leadership development through undergraduate leadership programs and the process of teaching leadership were learned. The history of Marietta College's McDonough Leadership program and its emphasis on leadership development and experiential learning was also explored.

In chapter three, the method and research design, sampling, data collection, instrumentation, validity, reliability, generalizability, data analysis, time line, and ethical issues for this research study will be examined. 


\section{Chapter Three}

\section{Method}

The purpose of this study was to explore the relationship between participation in the Marietta College McDonough Leadership program and student leadership development. Consideration was also given to the relationship between genders, major, race, and participation in experiential learning and student leadership development. Kouzes and Posner's (2005a; 2005b) Student Leadership Practices Inventory SLPI Self and SLPI - Observer pre-test and post-test surveys were utilized to answer the following research questions:

1. After participating in the McDonough leadership program at Marietta College, do college students demonstrate significant gains in the development of leadership behaviors as measured by the SLPI - Self and SLPI - Observer, according to the five leadership dimensions of Modeling the Way, Inspiring a Shared Vision, Challenging the Process, Enabling Others to Act, and Encouraging the heart?

2. As measured by the SLPI - Self and SLPI - Observer, is there a statistically significant difference in the development of leadership behaviors by gender after participating in the McDonough leadership program at Marietta College?

3. As measured by the SLPI - Self and SLPI - Observer, is there a statistically significant difference in the development of leadership behaviors by race after participating in the McDonough leadership program at Marietta College?

4. As measured by the SLPI - Self and SLPI - Observer, is there a statistically significant difference in the development of leadership behaviors by the type of 
McDonough Scholar including International Leadership Studies major, Leadership Studies minor, and Certificate of Leadership Studies after participating in the McDonough leadership program at Marietta College?

5. As measured by the SLPI - Self and SLPI - Observer, is there a statistically significant difference in the development of leadership behaviors by the type of experiential learning opportunity including internship, study abroad, and service project after participating in the McDonough leadership program at Marietta College?

This chapter reviews the scope of the study; the research participants;

instruments used in data collection; validity and reliability criteria for the instrument used; procedures used to measure the data; methods used to analyze the data; and ethical issues.

\section{Scope of the Study}

In an effort to show the relationship between leadership development programs like Marietta College's McDonough Leadership Program and leadership development, 50 participants were selected based on their involvement in Marietta College's McDonough Leadership program. It should be noted that the McDonough Leadership program already uses the SLPI instrument as part of its educational process; therefore previously collected data were used for the bulk of this research. This included students who took the SLPI from spring 2009 and 2010. It also included seniors from the 20102011 and 2011-2012 graduating classes.

In addition to the SLPI - Self survey, each student was also required to have three associates observe their leadership behaviors and respond to the SLPI - Observer 
survey. As a part of the 360 degree assessment process, the SLPI - Observer respondents were selected by the student. Students were required to select observers that observed them as seniors in high school (pre-test) and seniors at Marietta College (post-test). These observers viewed the participants as they participated in (a) community service activities; (b) educational events both in and out of the classroom; and (c) extra-curricular activities. The results of both the SLPI - Self and the SLPI Observer were used for this study.

\section{Research Participants}

Data for this study were collected from a mixture of male and female participants enrolled in the Marietta College McDonough Leadership program. This study included students enrolled at Marietta from 2008-2011. Participants were engaged in a variety of experiential learning activities, with an emphasis on community service, internships, and opportunities to study abroad. In order to collect demographic data and obtain permission to use previously collected results, Marietta College was provided a cover letter explaining the purpose of the study and the possible associated risks (Appendix

\section{A).}

Instrumentation

The study utilized the SLPI - Self and SLPI - Observer instruments. While working with the Dean of the McDonough Center for Leadership and Business, Gama Perruci, Ph.D., the demographic data were collected for the freshman and senior participants to determine gender, race, and type of McDonough Scholar (International Leadership Studies major, Leadership Studies minor, or Certificate of Leadership Studies). 
The SLPI - Self and SLPI - Observer instruments were chosen because they are the most widely used and well regarded leadership development instruments. The student version of the LPI-Self and LPI-Observer was created in the mid 1990's and its development, reliability, and validity have been well documented.

Data for this study were collected by administering the student version of the SLPI - Self and SLPI - Observer. Both instruments consist of 30 statements organized around five scales that measure the 5 practices of exemplary leadership. The participants ranked their responses on a 5 point Likert scale that ranges from 1 (rarely) to 5 (almost always). The SLPI - Self and SLPI - Observer can typically be completed in 10-15 minutes (Posner, 2010).

The original LPI's are leadership assessments that have been used in the corporate sector to evaluate the behaviors of leaders within the organization.

The SLPI - Self was designed to assess how often college students engage in Kouzes\& Posner's (2002) Five Practices of Exemplary Leadership. Basic wording was modified with the instruments. The directions were personalized for Marietta College participants.

A complete SLPI item breakdown can be found in Table 1.

The SLPI - Self and the SLPI - Observer consists of 30 statements, parallel to those on the original LPI. The statements are organized around five scales that measure the five practices of exemplary leadership. The participants ranked their responses on a 5-point Likert scale that ranged from 1 (rarely or seldom) to 5 (very frequently or almost always). 
Challenging the Process is the first scale or practice of exemplary leadership. This scale consists of six items. The SLPI - Self and the SLPI - Observer measures the degree to which students are willing to take risks and develop their skills and abilities.

The second leadership practice, Inspiring a Shared Vision also consisted of six items. The students participating in Marietta College's McDonough Leadership program who completed the Student LPI-Self were asked to rank the degree to which they looked ahead and communicated about what they believed would affect themselves in the future. Through the SLPI - Observer, students were observed based upon their effective ability to share their vision with others.

The third scale, Enabling Others to Act, consisted of six items. On the SLPI Self, participants were asked to measure the degree to which they treated others with dignity and respect. The SLPI - Observer also studied the participant's ability to actively listen to diverse points of view.

Modeling the Way is the fourth scale or practice of exemplary leadership. There are six statements to measure this practice. The participants who completed the Student LPI - Self were asked to assess to what degree they set a personal example of what is expected and to what degree they found ways to get feedback about how their actions affected other participants. Similarly, each participant selected approximately three observers to complete the SLPI - Observer pre- and post-test. Each observer rated how effective each participant was able to serve as role models through the way they served as leaders and interacted with followers.

The fifth and last scale is encouraging the heart. There are six statements to measure this scale. The participants who completed the SLPI-Self were asked to 
assess to what degree they gave support and expressed appreciation for others.

Similarly, the SLPI - Observer was used to better understand how the participant encouraged others in matters of the heart.

Table 1

Student Leadership Practices Inventory (SLPI) Item Breakdown

Scale Item \# Item

Challenging the Process

$3 \quad$ Looks around for ways to develop skills and abilities

8 Helps others take risks

13 Keeps current on events and activities

18 When things did not go as expected, asks the question "what can we learn from this experience?"

23 Makes sure that goals and plans are set

28 Takes initiative in experimenting with the way things are done

Inspiring a Shared Vision

2 Looks ahead and communicates about the future

7 Describes the ideal capabilities of others

12 Talks about a shared a vision

17 Shows others how their interests can be realized

22 Is upbeat and positive about what the group can achieve

27 Speaks with conviction about a higher purpose and meaning

Enabling Others to Act

$4 \quad$ Fosters cooperative rather than competitive relationships

9 Actively listens to diverse points of view

14 Treats others with dignity and respect

19 Supports the decisions other people make

24 Give people choices about how to do their work

29 Provides leadership opportunities

Modeling the Way

1 Sets a personal example of what they expect

$6 \quad$ Aligns others with principles and standards

11 Follows through on promises and commitments

16 Finds ways to get feedback about how actions affect others

21 Builds consensus on an agreed upon set of values

26 Talks about the values and principle that guide actions 
Encouraging the Heart

5 Praises people for a job well done

10 Encourages others

15 Provides support and appreciation

20 Publicly recognizes others

25 Finds ways to celebrate accomplishments

30 Creatively recognizes people

Demographic information was provided by Marietta College for each questionnaire. Demographics included gender, class status, race, and the type of McDonough Scholar who took the survey (including International Leadership Studies Major, Leadership Studies minor, and Certificate of Leadership Studies). The surveys also asked in which experiential learning opportunity the student participated. Each respondent's survey results were numbered. Only Marietta College knew the identity of each survey respondent.

Utilizing the SLPI - Self and SLPI - Observer through pre-test and post-test surveys, one can determine the relationship between leadership development and participating in Marietta College's McDonough Leadership program. Validity studies have shown that the more developmental opportunities in which the leaders have participated, the more frequently they report engaging in the five leadership practices. Likewise college students report engaging in the five leadership practices more frequently when they have had either more leadership experiences or more leadership development opportunities (Posner, 2010).

Furthermore, this study closely examined the relationship between a student's leadership development and their participation in experiential learning opportunities. 
These opportunities at Marietta College's McDonough Leadership program include a study abroad trip, service project, or internship. Students who majored in International Leadership Studies or minored in Leadership Studies were required to have at least one of these experiences by their junior year. Students participating in the Certificate of Leadership Studies were not required to complete a experiential learning experience.

\section{Validity and Reliability}

Validity is defined as the appropriateness, meaningfulness, and usefulness of specific conclusions made from test scores. It can also be defined as whether an instrument measures what it is designed to measure (Gall, Gall, \& Borg, 2003).

Validity tests continue to clearly show that due to the psychometric properties of the SLPI, leadership educators and student leaders themselves should have confidence that the instrument is a reliable assessment of their leadership behavior and valid indicator of their leadership effectiveness. Posner (2010) suggested the "SLPI can be used to establish baseline (first-time) data about the behaviors and skills of student leaders that can be used to further their subsequent leadership development" (p. 28). The SLPI assesses changes in leadership skills through the administration of pre- and post-treatment interventions (e.g., Posner, 2009). In this way, the SLPI can be employed by participants themselves as well as educators to track improvements in leadership behaviors over time.

The Five Practices of Exemplary Leadership model was developed from the analysis of over 11,000 administrations of both the long and short forms of the Personal Best Leadership Experience Questionnaire. Additionally, in-depth interviews with over 500 leaders from a wide spectrum of public and private organizations were analyzed. 
Their responses were distilled into the model of leadership. The behavior statements on the original and student versions of the LPI reflect this model (Kouzes \& Posner, 2002; Posner, 2004).

Content analysis on case studies from over 1,200 managers about their personal best leadership experiences were used to develop the original LPI. The development of the SLPI instruments followed the same case-study approach. Outstanding student leaders nominated for Leadership America, a national leadership development experience for college students, were asked to report their personal best leadership experience and the behaviors they thought were most critical to their success in this leadership experience. These students also participated in structured interviews, which were analyzed for leadership action and behavior themes (Posner, 2004).

The findings indicated that this model of leadership is relevant to the leadership experiences of college students. Researchers then assessed the statements on the original LPI instruments for congruence with the themes found in the student case studies. Items were modified to reflect terminology and concepts appropriate for use with a student population (Posner, 2004).

Twenty-three student senate leaders were used to test pilot the SLPI instruments. After completing the instruments, these students discussed the ambiguity and applicability of all test statements. Most of the statements $(83 \%)$ were determined to be understandable and consistent with terminology and concepts by student leaders. Problematic items were discussed, and improvements were determined.

These improvements to the SLPI included changes in language that was more understandable by students. In addition, statements more closely matched the types of 
experiences student leaders would exhibit which may differ from those experiences seen in leaders in business, government, non-profit sector, etc. These improvements helped improve the face validity of the SLPI, meaning the results which make sense to people (Posner, 2009).

Lastly, five student leaders who had not been previously involved with development efforts participated in a focus group discussion of the SLPI instruments. Only minor editorial changes were determined. These approaches to developing the instruments suggest items have a high degree of content validity (Posner, 2004).

Factor analysis was conducted to determine the degree to which the instruments measure common or different content areas. The results from a varimax rotation and Kaiser Normalization indicated that the original LPI-Self and LPI-Observer contain five factors with eight values greater than 1.0 and accounting for $60.5 \%$ of the variance. The factors were consistent with the Five Practices of Exemplary Leadership. Although some statements shared common variance on more than one factor, the highest loading was generally with other statements of one factor or scale (Kouzes \& Posner, 2002).

Regression analysis was performed, with leader effectiveness as the dependent variable and the five leadership practices as the independent variables. The regression equation was highly significant $(F=318.88, p<.0001)$. The leadership practices accounted for over $55 \%$ of the variance around the constituent assessment of the leaders' effectiveness. The regression analysis concluded that the results are meaningful (Kouzes \& Posner, 2002). 
In an assessment of 18 leadership instruments, the LPI was the only instrument to receive a top score in psychometric validity (Kouzes \& Posner, 2002). The LPI was rated the best of these instruments.

Reliability refers to the extent an instrument is able to measure a phenomenon consistently over time and populations (Gall et al., 2003). Internal reliability on the original LPI was measured by Cranach's alpha. The range of reliability coefficients for the five scales on the original LPI-Self was between .75 and .87. Reliability coefficients for the five scales on the original LPI-Observer, in which the relationship of the observer is other, were between .87 and .93 . Reliability coefficients for the five scales on the SLPI - Self were between .56 and .83 while the reliability coefficients for all five scales on the SLPI - Observer were between .73 and .90 . The conclusion was therefore made that the instruments are reliable (Kouzes \& Posner, 2002; Posner, 2004).

In addition, test-retest reliability (stability) has been evaluated on the original LPI. Test-retest reliability for the five leadership practices has been consistently strong at the .90 level and above. Since 1987, the comparison of LPI scores from participants in the Leadership Challenge Workshop in two-year intervals has shown considerable consistency across the five leadership practices (Kouzes\& Posner, 2002). These instruments are highly reliable.

\section{Data Process}

Subjects were selected using a convenience sampling method. The SLPI was given to participants in Marietta College's McDonough Leadership program from 20072008 through 2011-2012.This study included freshmen from 2007-2008 and 2008-2009 and seniors in the 2010-2011 and 2011-2012 graduating classes. 
None of the participants in the study was under the age of 18. Marietta College was provided a cover letter explaining the purpose and any associated risks of this research project (Appendix A). The cover letter and subsequent communication with Marietta College outlined the methodology of the research. The instrument and cover letter were approved by the Institutional Review Board (IRB) at West Virginia University (WVU). Marietta College gave approval for the study to be conducted on their campus and to use the McDonough Leadership students as research participants (Appendix B). The WVU IRB gave a Human Subjects exemption for the study (Appendix C).

\section{Data Analysis}

The data were separated into three categories: SLPI - Self results, SLPI Observer results, and demographics data. Demographic data were entered along with each SLPI - Self, and SLPI - Observer surveys.

The purpose of this study was to examine the relationship between participation in Marietta College's McDonough Leadership program and the leadership development of college students. Research questions focused on the type of experiential learning efforts and McDonough Scholar participants experienced as well as gender, race.

The data were exported from the LPI Scoring Software (Kouzes \& Posner, 2003) to the Statistical Package for Social Sciences (SPSS), Student Version 19.0. SPSS was used to conduct statistical analyses to answer the research questions posed in the study. Data were analyzed after the SLPI - Self and SLPI - Observer post-test were given in spring 2011 and fall 2011.

The SLPI - Self and SLPI - Observer results included results from the pre-test given during the student's freshman year at Marietta College and the post-test results 
given during the participant's senior year at Marietta College. In addition, each

participant had observers complete the SLPI -Observer survey for both the pre- and

post- test results. Those observing the student participants were different from the pre-

test and post-test, however the observers were chosen by the student in each case.

Research Question One: After participating in the McDonough leadership program at Marietta College, do college students demonstrate significant gains in the development of leadership behaviors as measured by the SLPI - Self and SLPI - Observer, according to the five leadership dimensions of Modeling the Way, Inspiring a Shared Vision, Challenging the Process, Enabling Others to Act, and Encouraging the Heart?

To respond to this question a total of $12 \mathrm{t}$-tests were performed for pre-and posttest results. This included t-tests on the overall results for the SLPI - Self and SLPI Observer and between each dimension of leadership (Table 2).

Table 2

T-Tests to be Calculated for Research Question 1

\begin{tabular}{|l|l|l|l|}
\hline$t$-test \#1 & Overall & Pre-Test Self & Post-Test Self \\
\hline$t$-test \#2 & Overall & Pre-Test Observer & Post-Test Observer \\
\hline$t$-test \#3 & Modeling the Way & Pre-Test Self & Post-Test Self \\
\hline$t$-test \#4 & Inspiring a Shared Vision & Pre-Test Self & Post-Test Self \\
\hline$t$-test \#5 & Challenging the Process & Pre-Test Self & Post-Test Self \\
\hline$t$-test \#6 & Enabling Others to Act & Pre-Test Self & Post-Test Self \\
\hline$t$-test \#7 & Encouraging the Heart & Pre-Test Self & Post-Test Self \\
\hline$t$-test \#8 & Modeling the Way & Pre-Test Observer & Post-Test Observer \\
\hline$t$-test \#9 & Inspiring a Shared Vision & Pre-Test Observer & Post-Test Observer \\
\hline$t$-test \#10 & Challenging the Process & Pre-Test Observer & Post-Test Observer \\
\hline$t$-test \#11 & Enabling Others to Act & Pre-Test Observer & Post-Test Observer \\
\hline$t$-test \#12 & Encouraging the Heart & Pre-Test Observer & Post-Test Observer \\
\hline
\end{tabular}




\begin{abstract}
Research Question Two: As measured by the SLPI - Self and SLPI Observer, is there a statistically significant difference in the development of leadership behaviors by gender after participating in the McDonough leadership program at Marietta College?
\end{abstract}

To respond to research question two, the difference between pre- and post-test scores was calculated for each individual by dimension. Demographic information was used to determine male/female groups. A total of 12 ANOVA's were performed for each dimension, by gender based on the difference between pre-and post test results.

ANOVA's were run for both SLPI - Self and SLPI-Observer.

Research Question Three: As measured by the SLPI - Self and SLPI Observer, is there a statistically significant difference in the development of leadership behaviors by race after participating in the McDonough leadership program at Marietta College?

Participants were not proportionately distributed by race. Therefore, the data were collapsed into two groups: Caucasian and non-Caucasian. The data were separated from the Student LPI-Self responses into those of Caucasian and nonCaucasian participants. A total of twelve ANOVAs were performed for pre-and post test results.
Research Question Four: As measured by the SLPI - Self and SLPI - Observer, is there a statistically significant difference in the development of leadership behaviors by the type of McDonough Scholar including International Leadership Studies major, Leadership Studies minor, and Certificate of Leadership Studies after participating in the McDonough leadership program at Marietta College?

The fourth research question posed in this study sought to reveal whether there were differences in the development of student leadership skills based upon whether or not a McDonough Scholar was receiving a International Leadership Studies major, Leadership Studies minor, or Certificate of Leadership Studies. A total of 12 ANOVAs were performed for pre-and post test results. 


\section{Research Question Five: As measured by the SLPI - Self and SLPI - Observer, is there a statistically significant difference in the development of leadership behaviors by the type of experiential learning opportunity including internship, study abroad, and service project after participating in the McDonough leadership program at Marietta College?}

The fifth research question posed in this study sought to better understand whether or not students developed differently as leaders based upon the experiential learning opportunities they participated in through the Marietta College McDonough Leadership program. These opportunities included study abroad trips, service projects, and internships. Each major and minor McDonough Scholar was required to attend at least one experience during their junior year. The Certificate of Leadership Studies students were not required to complete an experiential learning opportunity.

Participants were divided into four groups including those who participated in internships, study abroad trips, and service projects and those who did not participate in an experiential learning opportunity. The experiences were all semester long, however, each experience differed significantly.

Students attending Study Abroad trips often dealt with language and cultural barriers not experienced in the experiential learning opportunities. Participants of the Internships had direct supervision and unlike study abroad trips were often placed in situations where they were autonomous and independent. Students participating in service projects had little supervision and rather than be immersed in the experience, provided service intermittently throughout the semester.

\section{Ethical Issues}

Ethical practice in research means in order to gain "support from participants, a researcher conveys to participants that they are participating in a study, explains the 
purpose of the study, and does not engage in deception about the nature of the study" (Creswell, 1998, p. 132). Ethics is important enough, that it deserves discussion in all phases of the study.

The members responsible for developing strategies for maintaining ethical integrity included fact checking by the primary student researcher, the dissertation chairperson(s), dissertation committee and by gaining approval from the West Virginia University Institutional Board for the Protection of Human Subjects. Two areas that took special priority in assuring ethical integrity, included data collection and the analysis and dissemination of information. Expectations for the participants of this study were to determine what information to share and at what level of candor. Given that the bulk of the data were previously collected, this study focused on gathering demographic data through non-judgmental and ethical means while ensuring that previously collected data were collected in an ethical manner by Marietta College's McDonough Leadership program.

\section{Summary}

In conclusion, the purpose of this study was to examine the relationship between participation in Marietta College's McDonough Leadership program and the leadership development of college students. The study explored how participants developed among 5 leadership practices according to the SLPI - Self and SLPI - Observer. The research questions focused on differences in gender, race, type of McDonough Scholar, and participation in experiential learning opportunities including study abroad trips, service projects, and internships. 


\section{Chapter Four}

\section{Results}

\section{Introduction}

This chapter presents the major findings of the study, exploring the relationship between participation in the Marietta College McDonough Leadership program and student leadership development. This chapter compares the scores from two classes of freshman and seniors at Marietta College who participated in the McDonough Leadership program.

The findings are reported according to the five research questions. The overall purpose of the study was to determine whether participation in Marietta College's McDonough Leadership program had a impact on the development of leadership behaviors for these students as measured by the SLPI - Self and the SLPI - Observer (Kouzes \& Posner, 2005a; Kouzes \& Posner, 2005b).

The results were from the 2007 and 2008 freshman classes and the 2011 and 2012 graduating senior classes at Marietta College. Students of the McDonough Leadership program included those receiving a certificate of leadership, those who minored in Leadership Studies, and those majoring in International Leadership Studies. The Certificate of Leadership Studies students were added to obtain a sufficient sample size.

The following results analyzed the demographic variables of gender, race, and type of McDonough Scholar. In addition, Experiential Learning Opportunities experienced as part of the McDonough Leadership program were explored. 


\section{Response Rate}

A total of 50 students from Marietta College's McDonough Leadership program completed the SLPI - Self and SLPI - Observer. The SLPI - Self was completed by 50 students for both the pre-test and post-test. On average, three observers completed the SLPI - Observer pre-test per participant, and 2.13 observers completed the SLPI Observer post-test. The SLPI - Observers were chosen by the participants for their freshman and senior years.

The raw, anonymous data were provided to the researcher during visits in March and September 2011. The results from the freshman and senior classes included a $59 \%$ response rate. The pre-test represented freshman from the 2007-2008 and 2008-2009 classes. The post-test represented seniors from the 2010-2011 and 2011-2012 classes.

The participants consisted of $76 \%$ percent female $(N=38)$, and $24 \%$ were male $(N=12)$ (Table 3). The majority of the participants $(96 \%)$ were white. The remainder of the participants were considered minority and included one Latino and one Asian American. A total of $14 \%(N=7)$ of the participants majored in Leadership at Marietta College, while $86 \%(N=43)$ majored in other areas including Business, Biology, Chemistry, Marketing, and General Studies. Of the 43 students who did not major in leadership at Marietta College, 37\% $(N=16)$ minored in Leadership Studies and 63\% $(N=27)$ participated in the certificate of Leadership Studies program. 
Table 3

Student Characteristics

Number

$\%$

Gender

Female

38

12

$76 \%$

Male

Race

White

Minority

48

2

$24 \%$

Scholar

Leadership Studies Minor

International Leadership Studies Major

Certificate of Leadership Studies

16

7

27

$96 \%$

$4 \%$

$32 \%$

$14 \%$

$54 \%$

Experiential Learning Opportunity

None

Internship

9

$18 \%$

22

$44 \%$

Study Abroad

Service Project

17

$34 \%$

2

$N=50$

\section{Major Findings}

\section{Research question one.}

The first research question examined if college students demonstrate significant gains in the development of leadership behaviors after participating in Marietta College's McDonough Leadership program as measured by the SLPI - Self and SLPI Observer, according to the five leadership dimensions of Challenging the Process, Inspiring a Shared Vision, Enabling Others to Act, Modeling the Way, and Encouraging the Heart. The SLPI-Self and SLPI-Observer used a five-point Likert scale for 
responses. There were 30 items on the SLPI - Self and SLPI-Observer which were clustered into six items for each of the five leadership practices: (1) Challenging the Process, (2) Inspiring a Shared Vision, (3) Enabling Others to Act, (4) Modeling the Way, and (5) Encouraging the Heart. A paired $t$-test was used to determine the differences, if any, between the pre-test and post-test total scores and for each leadership practice.

\section{SLPI - self results.}

The total scores survey means and standard deviations for the SLPI - Self are shown in Table 4. A paired t-test yielded a statistically significant increase in SLPI - Self total scores from pre-test to post-test $(t(49)=4.3, p<.01)$. According to the paired ttest, the post-test means for the total survey scores in the SLPI- Self were significantly higher than the pre-test means for the total population $(N=50)$, revealing gains in their learning over time (Table 4).

Table 4

The Pre-Test and Post-Test Scores on the SLPI - Self

Leadership Practice

Total Scores

LP1 Challenging the Process

LP2 Inspiring a Shared Vision

LP3 Enabling Others to Act

LP4 Modeling the Way

LP5 Encouraging the Heart

\begin{tabular}{|c|c|c|c|c|c|}
\hline \multicolumn{2}{|l|}{ Pre-tes } & \multicolumn{2}{|c|}{ Post-test $(N=50)$} & \multirow[t]{2}{*}{$t$} & \multirow[t]{2}{*}{ ) } \\
\hline Mean & SD & Mean & SD & & \\
\hline 104.4 & 11.3 & 113.4 & 14.3 & 4.3 & $.000^{* *}$ \\
\hline 19.7 & 3.43 & 22.24 & 3.51 & 4. & $.000^{* *}$ \\
\hline 19. & 3.37 & .40 & 3.42 & 4.2 & $.000^{* *}$ \\
\hline 23.16 & 3.65 & 23.80 & 3.43 & 1.4 & 169 \\
\hline 0. & 3.03 & 22.20 & 3.68 & 2.1 & $.040^{*}$ \\
\hline 21.4 & 3.59 & 22.48 & 3.93 & 1.7 & .094 \\
\hline
\end{tabular}

${ }^{*} p<.05 \quad{ }^{* *} p<.01 \quad @ p<.10$ (Trend) 
The leadership practice that revealed the highest gains according to the SLPI Self survey was LP1, Challenging the Process. The mean of the LP1, Challenging the Process pre-test was 19.74 with a standard deviation of 3.43 , and the mean of the posttest scores of LP1 was 22.24, with a standard deviation of 3.51. A paired t-test demonstrated that there was a statistically significant gain $(t(49)=4.6, p<.01)$ on the mean score of LP1, Challenging the Process, between the SLPI- Self pre-tests and post-tests (Table 4).

The second highest scores according to the SLPI - Self was LP2, Inspiring a Shared Vision. The mean of the LP2, Inspiring a Shared Vision pre-test was 19.98 with a standard deviation of 3.37 , and the mean of the post-test scores of LP2 was 22.40 with a standard deviation of 3.42. A paired $t$-test showed that there was a statistically significant gain $(t(49)=4.2, p<.01)$ in the mean score of LP2, Inspiring a Shared Vision, between the SLPI - Self pre-tests and SLPI - Self post-tests (Table 4).

In addition, according to the SLPI - Self, LP4 Modeling the Way also showed statistically significant gains. The mean of the LP4, Modeling the Way pre-test was 20.94 with a standard deviation of 3.03 and the mean of the post-test scores of LP4 was 22.20 with a standard deviation of 3.68. A paired $t$-test showed that there was a statistically significant gain $(t(49)=2.1, p<.05)$ in the mean score of LP4, Modeling the Way, between the SLPI - Self pre-tests and SLPI - Self post-tests. The post-test score was significantly higher than that of the pre-test score (Table 4).

While gains were evident from the pre-test to post-test assessments through the SLPI - Self surveys for LP3, Enabling Others to Act and LP5, Encouraging the Heart, these gains were not considered statistically significant. The mean of the LP5, 
Encouraging the Heart, while not statistically significant, showed a strong trend toward statistical significance according to the SLPI- Self surveys. This trend was toward higher LP5 scores at post-test than at pre-test $(t(49)=1.7, p<.10)$. The mean of the LP5 pre-test was 21.40 with a standard deviation of 3.59 , compared to the mean of the post-test score of 22.48 with a standard deviation of 3.93 (Table 4).

The overall results from the paired samples t-tests revealed statistically significant differences between the scores of the pre-tests and post-tests according to the SLPI - Self Total Scores, LP1, Challenging the Process, LP2, Inspiring a Shared Vision, and LP4, Modeling the Way. In addition, results for LP5, Encouraging the Heart, showed a strong trend toward statistical significance (Table 4).

\section{SLPI - observer results.}

The total scores survey means and standard deviations for the SLPI - Observer are shown in Table 5. A paired $t$-test yielded a $p=.500$, indicating no statistically significant difference in SLPI - Observer total scores from pre-test to post-test. Thus, the SLPI - Observer showed no statistically significant gains between the scores of the preand post-tests in the total scores or any of the five dimensions of leadership. In fact, LP5, Encouraging the Heart showed a slight decline (Table 5). 
Table 5

The Pre-Test and Post-Test Scores on the SLPI - Observer

\begin{tabular}{llllllll} 
Leadership Practice & \multicolumn{2}{l}{ Pre-test $(N=50)$} & & \multicolumn{2}{l}{ Post-test $(N=42)$} & $t$ & $p$ \\
\cline { 2 - 3 } & Mean & SD & & Mean & SD & & \\
Total Scores & 118.7 & 13.6 & 119.9 & 11.9 & .500 & .620 \\
LP1 Challenging the Process & 22.92 & 3.06 & 23.73 & 2.89 & 1.43 & .158 \\
LP2 Inspiring a Shared Vision & 23.53 & 3.19 & 23.84 & 2.65 & .537 & .594 \\
LP3 Enabling Others to Act & 25.36 & 2.49 & 25.40 & 2.90 & .085 & .933 \\
LP4 Modeling the Way & 23.55 & 3.13 & 24.10 & 2.72 & 1.01 & .319 \\
LP5 Encouraging the Heart & 24.20 & 2.66 & 23.67 & 3.10 & .879 & .385
\end{tabular}

${ }^{*} p<.05 \quad{ }^{* *} p<.01$

\section{Research question two.}

Research Question Two examined the relationship gender played in leadership development among participants in Marietta College's McDonough Leadership program, as measured by the SLPI - Self and SLPI - Observer. This involved gender (male and female) as a between-subjects independent variable. Testing occasion (SLPI - Self pretest and post-test and SLPI - Observer pre- and post-test) was a within-subjects independent variable. The dependent variables were the total scores and the five dimensions of leadership survey scores. Thus, the research design to answer Research Question Two was a mixed measure Analysis of Variance (ANOVA) with one betweensubjects independent variable (Gender) and one within-subjects independent variable (Testing Occasion). 


\section{SLPI - self results.}

As can be seen in Table 6, when comparing men to women, only the LP3, Enabling Others to Act, showed a statistically significant difference in the interaction between males and females on the pre-test or post-test for the SLPI- Self (Figure 1). According to the mixed methods ANOVA, the $F$ value for the interaction between Gender and Occasion was 6.278 , with a $p$ value of $.016(p<.05)$. When examining the means of LP3, Enabling Others to Act, males showed a dramatic increase from pre-test to post-test (Table 7). However, females showed only a slight increase in means. Therefore, the development of behaviors related to the leadership practice of Enabling Others to Act yielded a statistically significant interaction of Gender $\times$ Occasion $(F(1)=$ $6.278, p<.05)$. This relationship is shown in Figure 1. 
Figure 1

LP3, Enabling Others to Act for Gender (SLPI - Self)

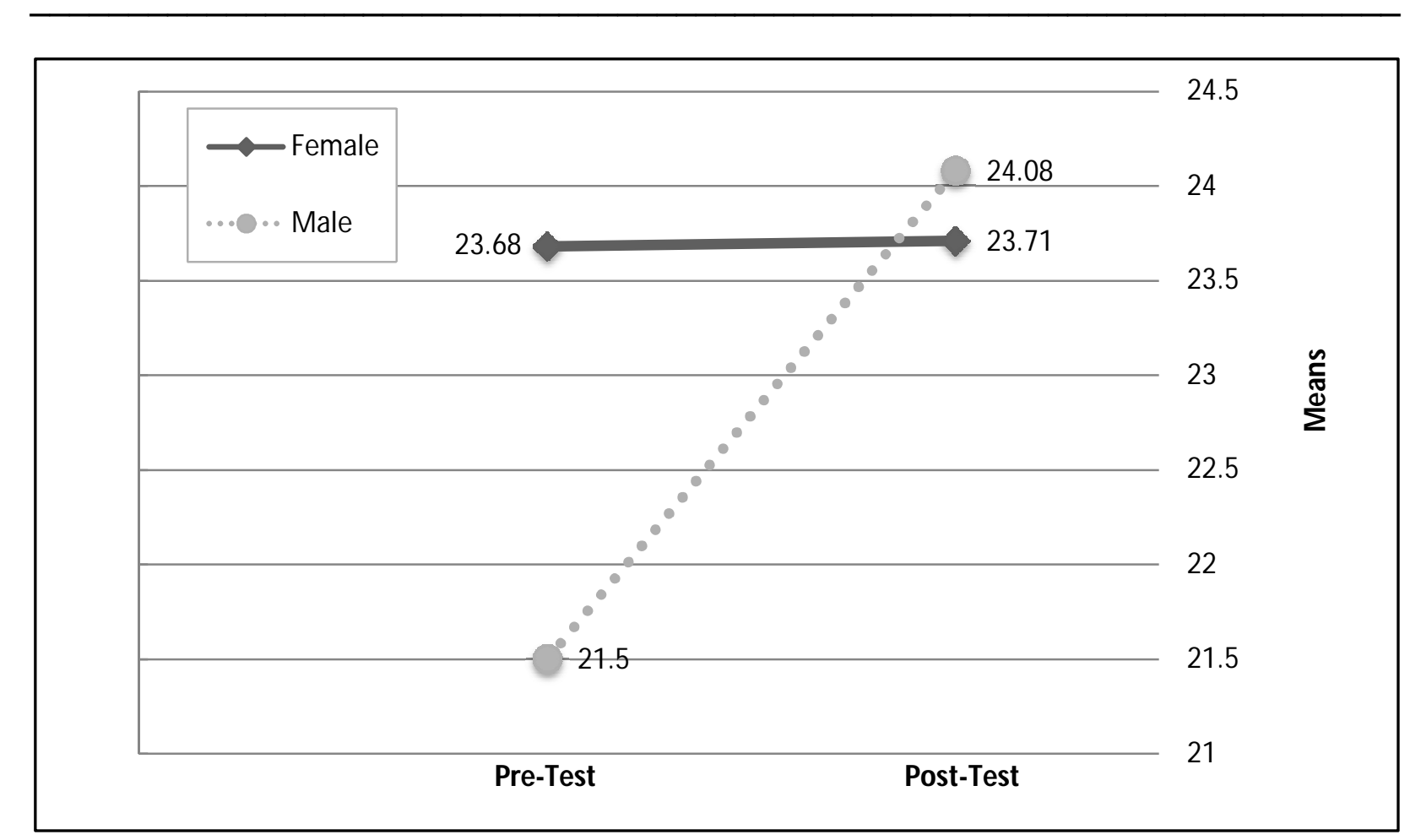

However, LP5, Encouraging the Heart showed a statistical significance in the between subjects analysis of gender. According to the SLPI - Self, LP5, Encouraging the Heart was statistically significant according to the main effect with an $F$ value of 5.362 and a $p$ value of $.025(p<.05$. $)$ Otherwise, there is no statistical significance in the relationship between Gender and the leadership development among participants according to the SLPI - Self (Table 6). 
Table 6

Gender and the Pre-Test and Post-Test Scores on the SLPI - Self

Total Scores

Gender (Male - Female)

Occasion (Pre - Post)

Interaction (Gender x Occasion)

df $\quad F \quad p$

LP1, Challenging the Process

Gender (Male - Female)

Occasion (Pre - Post)

Interaction (Gender x Occasion)

$\begin{array}{lll}1 & 0.522 & 0.474 \\ 1 & 14.05 & 0.000^{\star *} \\ 1 & 0.047 & 0.829\end{array}$

LP2, Inspiring a Shared Vision

Gender (Male - Female)

Occasion (Pre - Post)

Interaction (Gender x Occasion)

$\begin{array}{lll}1 & 0.763 & 0.387 \\ 1 & 15.87 & 0.000^{* *} \\ 1 & 0.064 & 0.801\end{array}$

LP3, Enabling Others to Act

Gender (Male - Female)

$\begin{array}{lll}1 & 0.751 & 0.390\end{array}$

Occasion (Pre - Post)

$1 \quad 6.539$

$0.014^{*}$

Interaction (Gender x Occasion)

$1 \quad 6.278$

$0.016^{*}$

LP4, Modeling the Way

Gender (Male - Female)

Occasion (Pre - Post)

Interaction (Gender x Occasion)

$\begin{array}{lll}1 & 0.011 & 0.917 \\ 1 & 1.612 & 0.210 \\ 1 & 1.062 & 0.308\end{array}$

LP5, Encouraging the Heart

Gender (Male - Female)

Occasion (Pre - Post)

Interaction (Gender x Occasion)

$\begin{array}{lll}1 & 5.362 & 0.025^{*} \\ 1 & 1.224 & 0.274 \\ 1 & 0.434 & 0.513\end{array}$

${ }^{*} p<.05 \quad{ }^{* *} p<.01$ 
Table 7

Gender and the Pre-Test and Post-Test Means and SD on the SLPI - Self

\begin{tabular}{|c|c|c|}
\hline \multirow{2}{*}{ Total } & Pre-Test Mean (SD) & \multirow{2}{*}{$\begin{array}{c}\text { Post-Test Mean (SD) } \\
113.84(14.8) \\
111.83(12.9)\end{array}$} \\
\hline & $\begin{array}{l}105.16(11.8) \\
102.08(9.6)\end{array}$ & \\
\hline \multicolumn{3}{|c|}{ LP 1, Challenging the Process } \\
\hline Female & $19.58(3.5)$ & $22.00(3.5)$ \\
\hline Male & $20.23(3.2)$ & $23.00(3.7)$ \\
\hline \multicolumn{3}{|c|}{ LP 2, Inspiring a Shared Vision } \\
\hline Female & $20.18(3.4)$ & $22.39(3.7)$ \\
\hline Male & $19.33(3.3)$ & $22.41(2.4)$ \\
\hline \multicolumn{3}{|c|}{ LP 3, Enabling Others to Act } \\
\hline Female & $23.68(3.5)$ & $23.71(3.5)$ \\
\hline Male & $21.50(3.7)$ & $24.08(3.5)$ \\
\hline \multicolumn{3}{|l|}{ LP 4, Modeling the Way } \\
\hline Female & $20.79(3.2)$ & $22.39(3.8)$ \\
\hline Male & $21.42(2.6)$ & $21.58(3.4)$ \\
\hline \multicolumn{3}{|c|}{ LP 5, Encouraging the Heart } \\
\hline Female & $21.82(3.5)$ & $23.13(3.8)$ \\
\hline Male & $20.08(3.7)$ & $20.42(3.7)$ \\
\hline
\end{tabular}


The results for the mixed method ANOVA, however, did match the $t$-Test scores found in RQ1. The within-subjects comparison of pre-test to post-test showed an increase in Total Scores according to the SLPI - self. The value was 14.05 and the statistical significance was $.000(p<.01)$.

A statistically significant increase was seen from pre-test to post-test scores in LP5, Challenging the Process according to the SLPI - Self. The $F$ value was 15.87 with a significance of $p=.000 .(p<.01)$. Similarly, a strong relationship was seen between LP5, Inspiring a Shared Vision and participants of Marietta College's McDonough Leadership program. The $F$ value was found to be 15.51 with a significance level of $p=$ $.000(p<.01)$.

Two differences were noted between the mixed method ANOVA test between pre-test and post-test according to the SLPI - Self and the $t$-Test scores found in RQ1. LP4, Modeling the Way showed statistical significance according to the paired samples $t$-Test; however, according to the ANOVA LP4 received a $p$ value of $.210(p>.05)$ and was not considered statistically significant. In addition, LP3, Enabling Others to Act, was not statistically significant according to the paired samples $t$-Test, but was considered statistically significant according to the ANOVA with an $F$ value of 6.539 and a $p$ value of $.014 .(p<.05)$.

Even though it is not statistically significant an interesting relationship is shown in Figure 2. As shown in Figure 2, females, in LP4, Modeling the Way showed noticeable gains from pre-test to post-test, while male participants showed only a nominal increase in mean from freshman to senior years according to the SLPI - Self. Therefore, female 
participants showed noticeable gains in behaviors related to LP4, Modeling the Way, while males did not.

Figure 2

LP4, Modeling the Way for Gender (SLPI - Self)

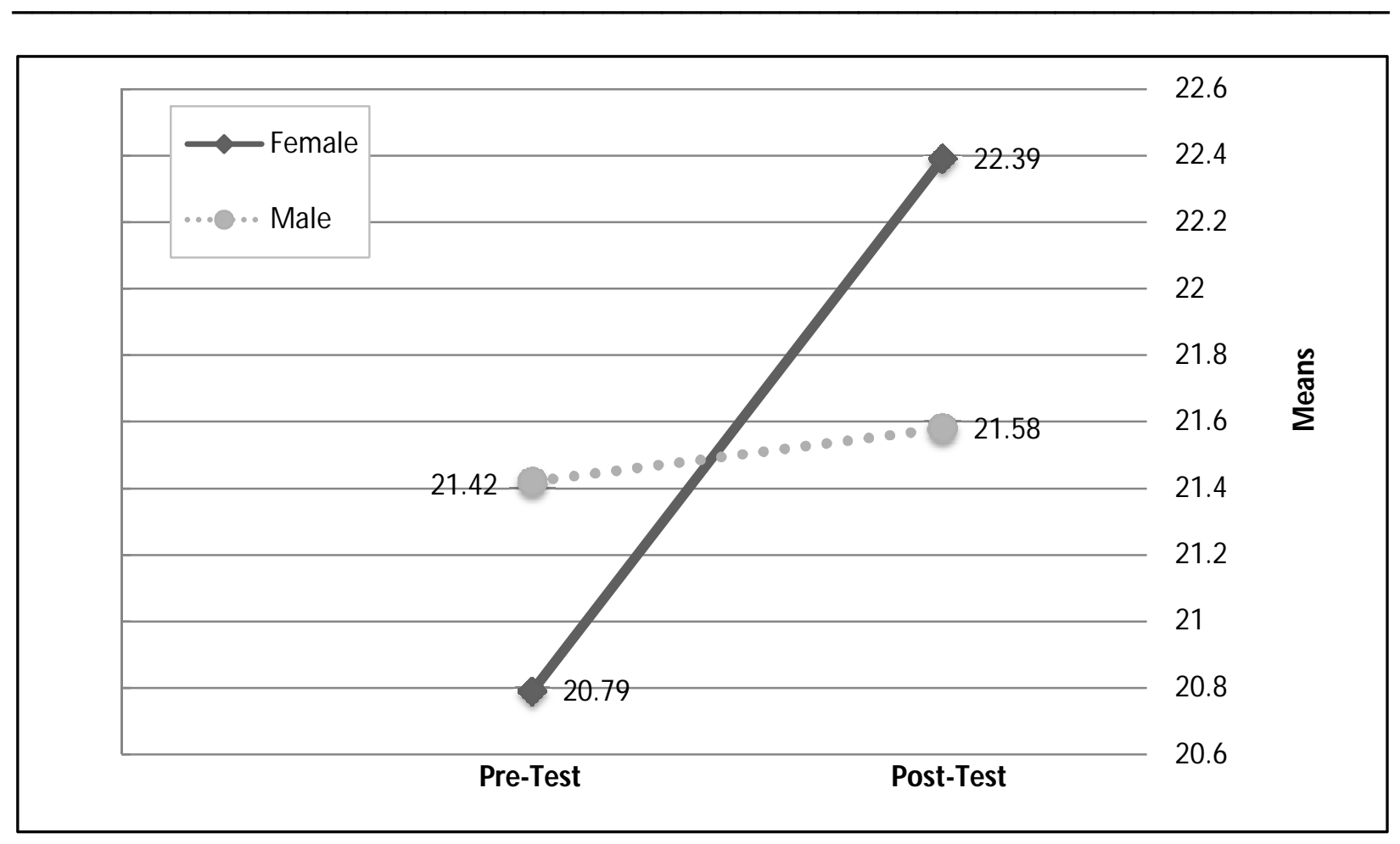

\section{SLPI - observer results.}

According to the mixed method ANOVA tests for Research Question Two, there is no statistical significance in the relationship between Gender and the leadership development among study participants according to the SLPI - Observer (Table 9). Further examination, however, noted interesting results for LP5, Encouraging the Heart.

Even though it was not statistically significant, an interesting relationship is shown in Figure 3. According to the SLPI - Observer, male participants showed notable 
increases from freshman to senior year in behaviors associated with LP5, Encouraging the Heart. However, female students showed a notable decrease from pre-test to posttest (Figure 3).

Table 8

Gender and the Pre-Test and Post-Test Scores on the SLPI - Observer

\begin{tabular}{llcc}
\hline Total Scores & $d f$ & $F$ & $p$ \\
Gender (Male - Female) & 1 & 0.300 & 0.587 \\
Occasion (Pre - Post) & 1 & 0.173 & 0.680 \\
Interaction (Gender x Occasion) & 1 & 0.000 & 0.992 \\
\hline
\end{tabular}

LP1, Challenging the Process

$\begin{array}{llll}\text { Gender (Male - Female) } & 1 & 0.058 & 0.810 \\ \text { Occasion (Pre - Post) } & 1 & 1.968 & 0.168 \\ \text { Interaction (Gender x Occasion) } & 1 & 0.133 & 0.718\end{array}$

LP2, Inspiring a Shared Vision

Gender (Male - Female)

Occasion (Pre - Post)

Interaction (Gender x Occasion)

$\begin{array}{lll}1 & 0.021 & 0.884 \\ 1 & 0.297 & 0.589 \\ 1 & 0.031 & 0.861\end{array}$

LP3, Enabling Others to Act

Gender (Male - Female)

Occasion (Pre - Post)

Interaction (Gender x Occasion)

$\begin{array}{lll}1 & 0.334 & 0.567 \\ 1 & 0.022 & 0.882 \\ 1 & 0.022 & 0.882\end{array}$

LP4, Modeling the Way

Gender (Male - Female)

Occasion (Pre - Post)

Interaction (Gender x Occasion)

$\begin{array}{lll}1 & 0.201 & 0.656 \\ 1 & 1.484 & 0.230 \\ 1 & 0.486 & 0.490\end{array}$

LP5, Encouraging the Heart

Gender (Male - Female)

Occasion (Pre - Post)

Interaction (Gender x Occasion)

$\begin{array}{lll}1 & 2.255 & 0.141 \\ 1 & 0.013 & 0.911 \\ 1 & 1.496 & 0.228\end{array}$


${ }^{*} p<.05 \quad{ }^{* *} p<.01$

76|P a g e 
Table 9

Gender and the Means \& Standard Deviations on the SLPI - Observer

\begin{tabular}{|c|c|c|}
\hline & -Test Mean $(S D)$ & Post-Test Mean (SD) \\
\hline $\begin{array}{l}\text { Female } \\
\text { Male }\end{array}$ & $\begin{array}{l}119.21(14.6) \\
117.21(10.2)\end{array}$ & $\begin{array}{l}120.42(13.1) \\
118.35(6.9)\end{array}$ \\
\hline $\begin{array}{l}\text { LP1, Challenging the Process } \\
\text { Female } \\
\text { Male }\end{array}$ & $\begin{array}{l}22.93(3.2) \\
22.90(2.6)\end{array}$ & $\begin{array}{l}23.63(2.9) \\
24.08(2.9)\end{array}$ \\
\hline $\begin{array}{c}\text { LP2, Inspiring a Shared Vision } \\
\text { Female } \\
\text { Male }\end{array}$ & $\begin{array}{l}23.53(3.5) \\
23.53(2.2)\end{array}$ & $\begin{array}{l}23.78(2.7) \\
24.02(2.7)\end{array}$ \\
\hline $\begin{array}{l}\text { LP3, Enabling Others to Act } \\
\text { Female } \\
\text { Male }\end{array}$ & $\begin{array}{l}25.50(2.5) \\
24.93(2.6)\end{array}$ & $\begin{array}{l}25.50(2.2) \\
25.08(2.0)\end{array}$ \\
\hline $\begin{array}{l}\text { LP4, Modeling the Way } \\
\text { Female } \\
\text { Male }\end{array}$ & $\begin{array}{l}23.57(3.3) \\
23.50(2.6)\end{array}$ & $\begin{array}{l}23.91(2.8) \\
24.74(2.5)\end{array}$ \\
\hline $\begin{array}{c}\text { LP5, Encouraging the Heart } \\
\text { Female } \\
\text { Male }\end{array}$ & $\begin{array}{l}24.68(2.5) \\
22.68(2.6)\end{array}$ & $\begin{array}{l}23.73(3.4) \\
23.47(1.9)\end{array}$ \\
\hline
\end{tabular}


Figure 3

LP5, Encouraging the Heart (SLPI - Observer)

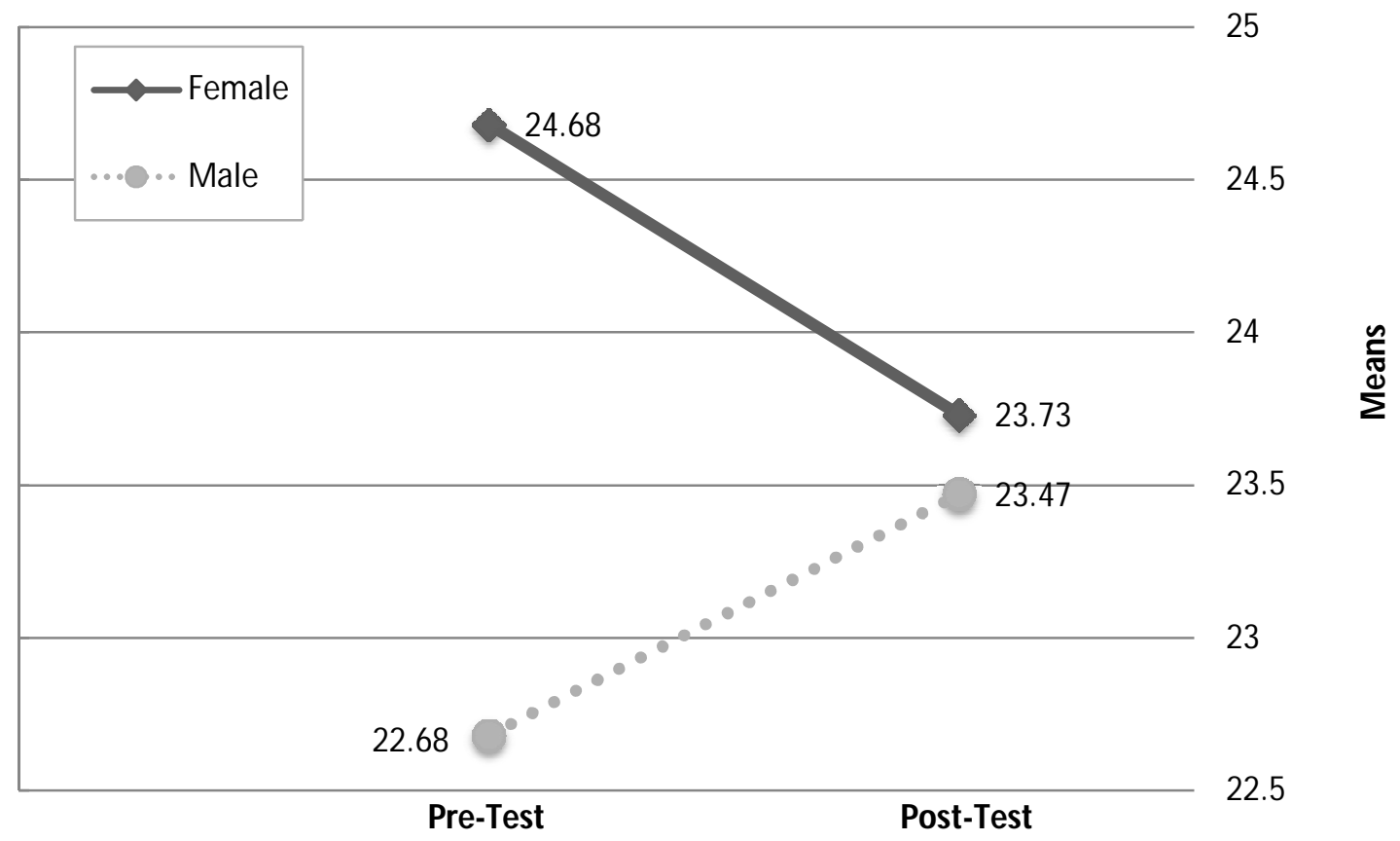

Research question three.

Research Question Three examined if there was a statistically significant difference in the development of leadership behaviors by race. The majority of the participants were white $(N=48,94 \%)$

There were only two non-Caucasian students, one Latino and one AsianAmerican. Therefore, no statistical data could be calculated for Research Question Three. 


\section{Research question four.}

Research Question Four examined if there was a statistically significant difference in the development of leadership behaviors by the type of McDonough Scholar including International Leadership Studies major, Leadership Studies minor, and certificate of Leadership Studies after participating in the McDonough leadership program at Marietta College, as measured by the SLPI - Self and SLPI - Observer. The between subjects independent variable was McDonough Scholar (International Leadership Studies major, Leadership Studies minor, and Certificate of Leadership Studies). Testing occasion (SLPI - Self pre-test and post-test and SLPI - Observer pretest and post-test) was a within-subjects independent variable. The dependent variables were the total scores and the five dimensions of leadership survey scores. Thus, the research design to answer Research Question Four was a mixed measure ANOVA with one between-subjects independent variable (McDonough Scholar) and one withinsubjects independent variable (Testing Occasion).

\section{SLPI - self results.}

When comparing the type of McDonough Scholar to the pre- and post-test scores according to the SLPI - Self, no significant difference was evident for the total scores or any of the leadership practices. There was no statistically significant difference in the between subjects interaction between International Leadership Studies majors, Leadership Studies minor, or Certificate of Leadership studies students in relationship to total scores or any of the five leadership practices according to the SLPI- Self (Table 10). The means and standard deviations are reported in Table 11. 
Table 10

Type of McDonough Scholar and the Pre-Test and Post-Test Scores on the SLPI - Self

Total Scores

McDonough Scholar (major, minor\& certificate)

$\begin{array}{lll}d f & F\end{array}$

Occasion (Pre - Post)

Interaction (McDonough Scholar x Occasion)

2

1

2

0.184

0.833

15.06

$.000^{* *}$

0.656

LP1, Challenging the Process

$\begin{array}{llll}\text { McDonough Scholar (major, minor\& certificate) } & 2 & 0.858 & 0.430\end{array}$

Occasion (Pre - Post)

Interaction (McDonough Scholar x Occasion)

$1 \quad 13.68$

$.001^{* *}$

$2 \quad 0.074$

0.929

LP2, Inspiring a Shared Vision

$\begin{array}{llll}\text { McDonough Scholar (major, minor\& certificate) } & 2 & 0.157 & 0.855\end{array}$

Occasion (Pre - Post)

$1 \quad 11.69$

$.001^{* *}$

Interaction (McDonough Scholar x Occasion)

2

0.052

0.949

LP3, Enabling Others to Act

McDonough Scholar (major, minor\& certificate)

Occasion (Pre - Post)

Interaction (McDonough Scholar x Occasion)

$\begin{array}{lll}2 & 0.850 & 0.434 \\ 1 & 1.315 & 0.257 \\ 2 & 0.077 & 0.926\end{array}$

LP4, Modeling the Way

$\begin{array}{llll}\text { McDonough Scholar (major, minor\& certificate) } & 2 & 0.546 & 0.583\end{array}$

Occasion (Pre - Post)

Interaction (McDonough Scholar x Occasion)

$1 \quad 3.97$

$2 \quad 0.084$

.052@

0.920

LP5, Encouraging the Heart

$\begin{array}{llll}\text { McDonough Scholar (major, minor\& certificate) } & 2 & 0.293 & 0.747\end{array}$

Occasion (Pre - Post)

Interaction (McDonough Scholar x Occasion)

$1 \quad 4.077$

$2 \quad 0.917$

$0.049^{*}$

0.407

${ }^{*} p<.05 \quad{ }^{* *} p<.01 \quad @ p<.10$ (Trend) 
Table 11

McDonough Scholars and the Means \& Standard Deviations on the SLPI - Self

Total

Pre-Test Mean (SD) Post-Test Mean (SD)

$\begin{array}{lll}\text { Minor } & 101.81(10.7) & 113.31(14.8) \\ \text { Major } & 105.00(13.3) & 114.71(16.3) \\ \text { Certificate } & 105.81(11.4) & 113.03(13.9)\end{array}$

LP1, Challenging the Process

Minor

Major

$18.94(3.6)$

$20.86(3.5)$

$21.63(3.9)$

Certificate

$19.93(3.4)$

$22.86(4.6)$

$22.44(3.1)$

LP2, Inspiring a Shared Vision

Minor

Major

$20.00(3.7)$

$22.38(4.1)$

$20.71(3.9)$

$22.71(2.4)$

Certificate

$19.80(3.1)$

$22.33(3.3)$

LP3, Enabling Others to Act

Minor

Major

$22.50(3.3)$

$23.00(3.5)$

23.59 (3.9)

$22.88(4.2)$

$23.71(4.2)$

Certificate

$24.37(2.7)$

LP4, Modeling the Way

Minor

$21.25(3.0)$

$21.29(3.3)$

Major

$20.67(3.1)$

$22.50(3.9)$

$23.14(3.8)$

Certificate

$20.67(3.1)$

$21.78(3.6)$

LP5, Encouraging the Heart

Minor

$21.25(3.6)$

Major

$20.00(3.7)$

23.13 (3.3)

Certificate

$21.85(3.6)$

$22.29(3.1)$

$22.15(4.5)$ 
However, in the within subjects analysis of Occasion, an $F$ value of 15.06 and a statistical significance of $p=.000$ was noted for total scores. Thus, the combined minor, major, and certificate main effect increased significantly from pre-test to post-test. This matches what was seen in the RQ1 $t$-Test results. Therefore participants showed an overall increase in total scores according to the SLPI - Self, which represents a significant growth in leadership development from freshman to senior year.

Similarly, in the within subjects comparison for the SLPI - Self, the results for Challenging the Process Pre- and Post-test results showed an Fvalue of 13.68 and a statistical significance of $(p=.001)$. This also matches what was seen in the RQ1 $t$-Test results. Participants showed an increase in results from Challenging the Process according to the SLPI - Self, which represents a growth in behaviors like learning from past experiences and taking initiative from freshman to senior years.

Also, in the within subjects comparison for the SLPI - Self, the results for Inspiring a Shared Vision Pre- and Post-test results showed an $F$ value of 11.69 and a statistical significance of $p=.001$. This matches what was seen in the RQ1 $t$-Test results. Participants showed an increase in behaviors represented by the leadership practice Inspiring a Shared Vision according to the SLPI - Self. This represents a growth in behaviors like developing a shared vision and speaking with conviction about a higher purpose and meaning from freshman to senior years.

Like the ANOVA for gender, there were some differences between the RQ1 $t$ Test noted as well. According to the SLPI - Self, LP5, Encouraging the Heart showed an $F$ value of 4.077 and a $p$ value of .049 through the mixed method ANOVA, but it was not considered statistically significant in the RQ1 $t$-Test. Similarly, according to the 
SLPI - Self through the mixed method ANOVA, LP4, Modeling the Way trended toward significance with an $F$ value of 3.97 and a $p$ value of .052 , but was not considered statistically significant (or trending toward significance) according to the RQ1 t-Test.

\section{SLPI - observer results.}

There were no statistically significant difference in the within subjects interaction between International Leadership Studies majors, Leadership Studies minor, or Certificate of Leadership studies students in relationship to total scores or any of the five leadership practices according to the SLPI - Observer (Table 12).

Even though it was not statistically significant, an interesting relationship is shown in Figure 4. According to the SLPI - Observer, McDonough scholar minor and major participants showed notable increases from freshman to senior year in behaviors associated with LP3, Enabling Others to Act. However, certificate of Leadership Studies participants showed a notable decline from pre-test to post-test (Figure 4). 
Figure 4

LP3, Enabling Others to Act for McDonough Scholar (SLPI - Observer)

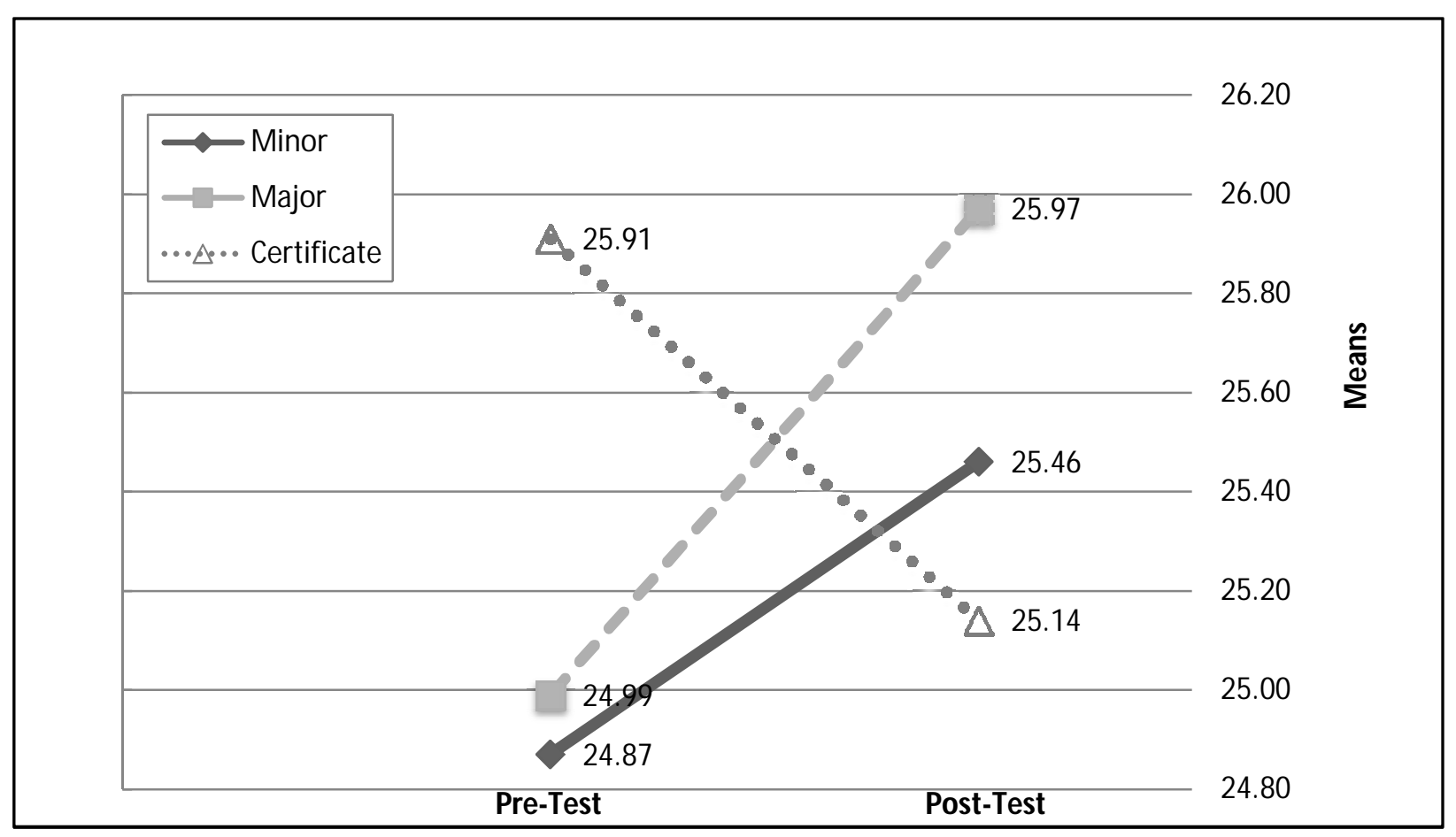


Table 12

McDonough Scholar and the Pre-Test \& Post-Test Scores on the SLPI-Observer

Total Scores

$\begin{array}{llll}\text { McDonough Scholar (major, minor\& certificate) } & 2 & 0.708 & 0.499\end{array}$

Occasion (Pre - Post)

Interaction (McDonough Scholar x Occasion)

$1 \quad 0.072$

0.790

2

0.163

0.850

LP1, Challenging the Process

$\begin{array}{llll}\text { McDonough Scholar (major, minor\& certificate) } & 2 & 0.179 & 0.837\end{array}$

Occasion (Pre - Post)

Interaction (McDonough Scholar x Occasion)

$1 \quad 1.31$

0.259

$\begin{array}{lll}1 & 0.112 & 0.894\end{array}$

LP2, Inspiring a Shared Vision

$\begin{array}{llll}\text { McDonough Scholar (major, minor\& certificate) } & 2 & 0.654 & 0.525\end{array}$

Occasion (Pre - Post)

$1 \quad 0.081$

0.777

Interaction (McDonough Scholar x Occasion)

2

0.179

0.836

LP3, Enabling Others to Act

McDonough Scholar (major, minor\& certificate)

Occasion (Pre - Post)

Interaction (McDonough Scholar x Occasion)

$\begin{array}{lll}2 & 0.108 & 0.897 \\ 1 & 0.337 & 0.565 \\ 2 & 1.64 & 0.207\end{array}$

LP4, Modeling the Way

$\begin{array}{llll}\text { McDonough Scholar (major, minor\& certificate) } & 2 & 1.06 & 0.356\end{array}$

Occasion (Pre - Post)

Interaction (McDonough Scholar x Occasion)

$1 \quad 0.325$

0.572

$2 \quad 0.353 \quad 0.705$

LP5, Encouraging the Heart

$\begin{array}{llll}\text { McDonough Scholar (major, minor\& certificate) } & 2 & 1.53 & 0.230\end{array}$

Occasion (Pre - Post)

Interaction (McDonough Scholar x Occasion)

$1 \quad 1.31$

0.259

$2 \quad 0.526 \quad 0.595$

${ }^{*} p<.05 \quad{ }^{* *} p<.01$ 
Table 13

McDonough Scholars and the Means \& Standard Deviations on the SLPI - Observer

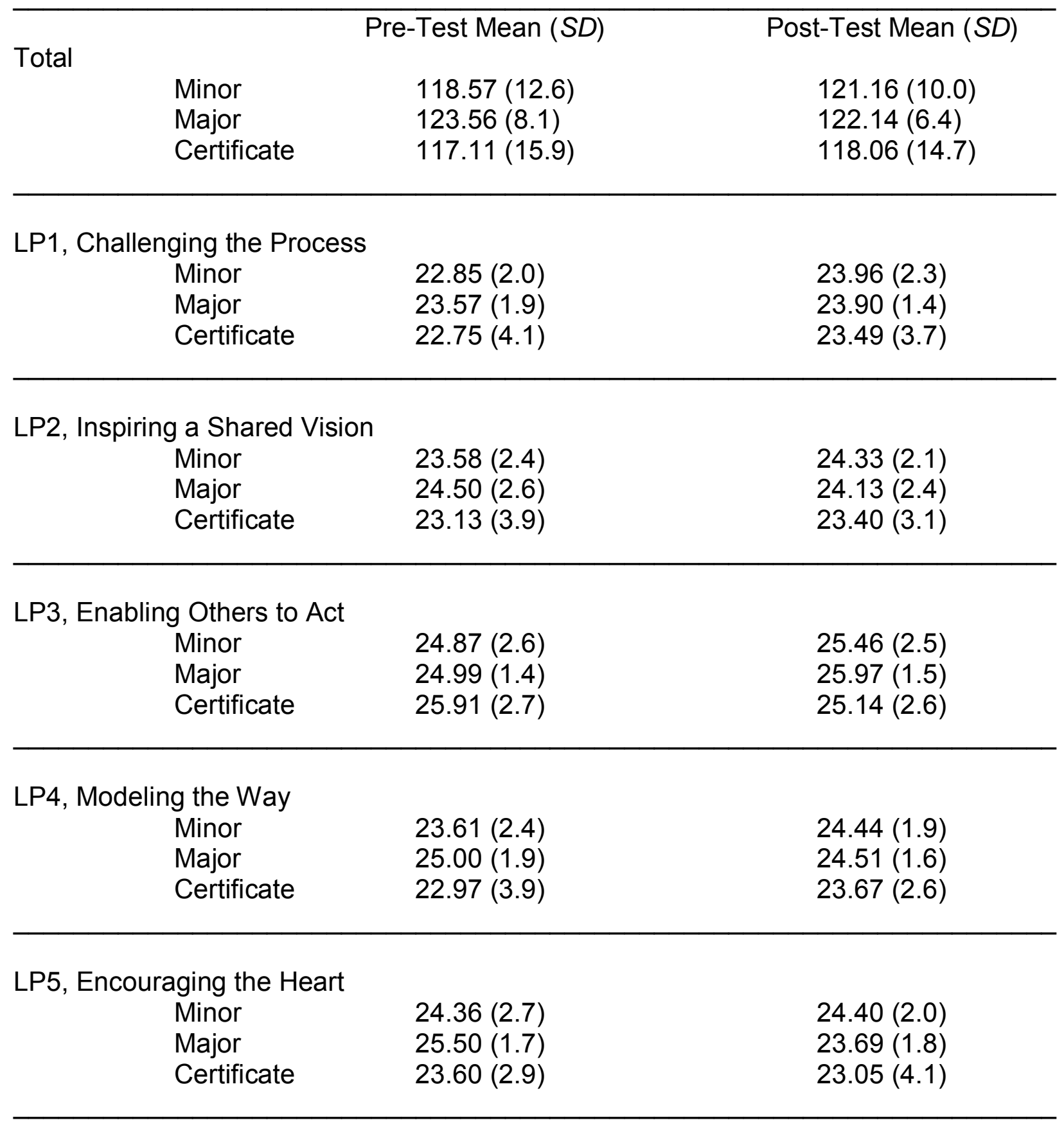




\section{Research question five.}

The fifth and final research question examined if there was a statistically significant difference in the development of leadership behaviors by Experiential Learning Opportunity including None, Internship, Study Abroad, and Service Project, as measured by the SLPI - Self and SLPI - Observer. The between subjects independent variable was Experiential Learning Opportunity (None, Internship, Study Abroad, and Service Project). Testing Occasion (SLPI - Self Pre- and Post-test and SLPI - Observer Pre- and Post-test) was a within-subjects independent variable. The dependent variables were the total scores and the five dimensions of leadership survey scores.

Thus, the research design to answer Research Question Five was a mixed measure Analysis of Variance (ANOVA) with one between-subjects independent variable (Experiential Learning Opportunity) and one within-subjects independent variable (Testing Occasion).

\section{SLPI - self results.}

When comparing Experiential Learning Opportunity scores to the pre-test and post-test scores according to the SLPI - Self, no statistically significant interactions were evident for the total scores or any of the leadership practices. Additionally, with reference to Experiential Learning Opportunity (None, Internship, Study Abroad, or Service Project) there was no statistically significant difference found in the main effect relationship to total scores or any of the five leadership practices according to the SLPISelf (Table 14). 
Table 14

Experiential Learning Opportunity \& Pre-Test and Post-Test Scores on the SLPI - Self

Total Scores

Experiential Learning (None, Internship, Study Abroad, Svs. Proj.) $\quad 3 \quad .357 \quad .784$

Occasion (Pre - Post)

Interaction (Experiential Learning $x$ Occasion)

$1 \quad 5.32$

3.343

$.026^{*}$

.794

LP1, Challenging the Process

Experiential Learning (None, Internship, Study Abroad, Svs. Proj.) $\quad 3 \quad .158 \quad .924$

Occasion (Pre - Post)

Interaction (Experiential Learning $x$ Occasion)

$1 \quad 6.00$

$.018^{*}$

$3 \quad .205 \quad .892$

LP2, Inspiring a Shared Vision

Experiential Learning (None, Internship, Study Abroad, Svs. Proj.)

Occasion (Pre - Post)

Interaction (Experiential Learning $x$ Occasion)

$1 \quad 11.21$

$3 \quad .412$

$.002^{* *}$

.745

LP3, Enabling Others to Act

Experiential Learning (None, Internship, Study Abroad, Svs. Proj.)

Occasion (Pre - Post)

Interaction (Experiential Learning x Occasion)

$3 \quad 1.49$

.229

$1 \quad .005$

.943

$3 \quad .559$

.645

LP4, Modeling the Way

Experiential Learning (None, Internship, Study Abroad, Svs. Proj.) $\quad 3 \quad .050 \quad .985$

Occasion (Pre - Post)

Interaction (Experiential Learning $x$ Occasion)

$1 \quad 2.02$

.162

$3 \quad .354$

.786

LP5, Encouraging the Heart

Experiential Learning (None, Internship, Study Abroad, Svs. Proj.) $\quad 3 \quad .684 \quad .566$

Occasion (Pre - Post)

$1 \quad .178 \quad .675$

Interaction (Experiential Learning $x$ Occasion)

$3 \quad .846$

.476

${ }^{*} p<.05 \quad{ }^{* *} p<.01$ 
In the within subjects comparison for the SLPI - Self, the Total Scores for the pretest and post-test results showed an $F$ value of 5.32 and a statistical significance of ( $p$ $=.026)$ (Table 14). This matches what was seen in the RQ1 $t$-Test results with participants showing an increase in results from Total Scores according to the SLPI Self. The means and standard deviations appear in Table 15.

Similarly, the results for LP1, Challenging the Process pre- and post-test scores according to the SLPI - Self showed an $F$ value of 6.00 and a $p$ value of .018 . This matches what was seen in the RQ1 $t$-Test results. The results for LP2, Inspiring a Shared Vision pre- and post-test scores according to the SLPI - Self showed an F value of 11.21 and a statistical significance of $(p=.002)$. This also matches what was seen in the RQ1 t-Test results.

Further examination of the data noted interesting results according to the SLPI Self. The total scores for the participants of Study Abroad trips showed a notable increase between scores from the pre-test to the post-test. The Study Abroad and Internship increases were notably higher than participants who did not participate in an experiential learning opportunity (None) or students who participated in Service Projects (Figure 5). 
Table 15

Experiential Learning and the Means \& Standard Deviations on the SLPI - Self

Total

Pre-Test Mean $(S D)$

$\begin{array}{ll}\text { None } & 107.56(11.0) \\ \text { Internship } & 102.14(8.8) \\ \text { Study Abroad } & 105.29(14.7) \\ \text { Service Project } & 108.00(2.8)\end{array}$

None

Service Project
$102.14(8.8)$

$108.00(2.8)$
Post-Test Mean (SD)

$112.6(12.5)$

$112.09(16.1)$

$115.52(13.9)$

$112.00(9.9)$

\begin{tabular}{ccc}
\hline LP1, Challenging the Process & & \\
None & $19.11(2.5)$ & $21.78(3.1)$ \\
Internship & $19.72(3.2)$ & $22.45(3.8)$ \\
Study Abroad & $19.88(4.3)$ & $22.24(3.5)$ \\
Service Project & $21.50(.71)$ & $22.00(5.7)$ \\
& & \\
\hline LP2, Inspiring a Shared Vision & & $22.56(2.7)$ \\
None & $19.33(3.4)$ & $22.09(4.0)$ \\
Internship & $20.31(2.7)$ & $22.53(3.2)$ \\
Study Abroad & $19.88(4.3)$ & $24.00(2.8)$ \\
Service Project & $20.00(1.4)$ & \\
& & $23.89(3.1)$ \\
& & $23.09(3.6)$ \\
\hline LP3, Enabling Others to Act & $24.00(3.2)$ & $24.94(3.3)$ \\
None & $22.05(3.6)$ & $21.5(2.1)$ \\
Internship & $24.18(3.9)$ & \\
Study Abroad & $23.00(1.4)$ & $21.78(4.4)$ \\
Service Project & & $22.00(4.1)$ \\
& & $22.65(3.0)$ \\
None & $21.67(3.0)$ & $22.50(2.1)$ \\
Internship & $20.82(2.9)$ & \\
Study Abroad & $20.76(3.5)$ & $22.78(3.0)$ \\
Service Project & $20.50(.73)$ & $22.05(4.8)$ \\
& & $22.00(3.4)$ \\
\hline LP4, Modeling the Way & & \\
\hline None & $23.44(4.3)$ & \\
Internship & $20.77(2.5)$ & \\
Study Abroad & $20.94(4.2)$ & \\
Service Project & $23.00(4.2)$ & \\
\hline LP5, Encouraging the Heart & & \\
\hline
\end{tabular}


Figure 5

Total Scores for Experiential Learning Opportunity (SLPI - Self)

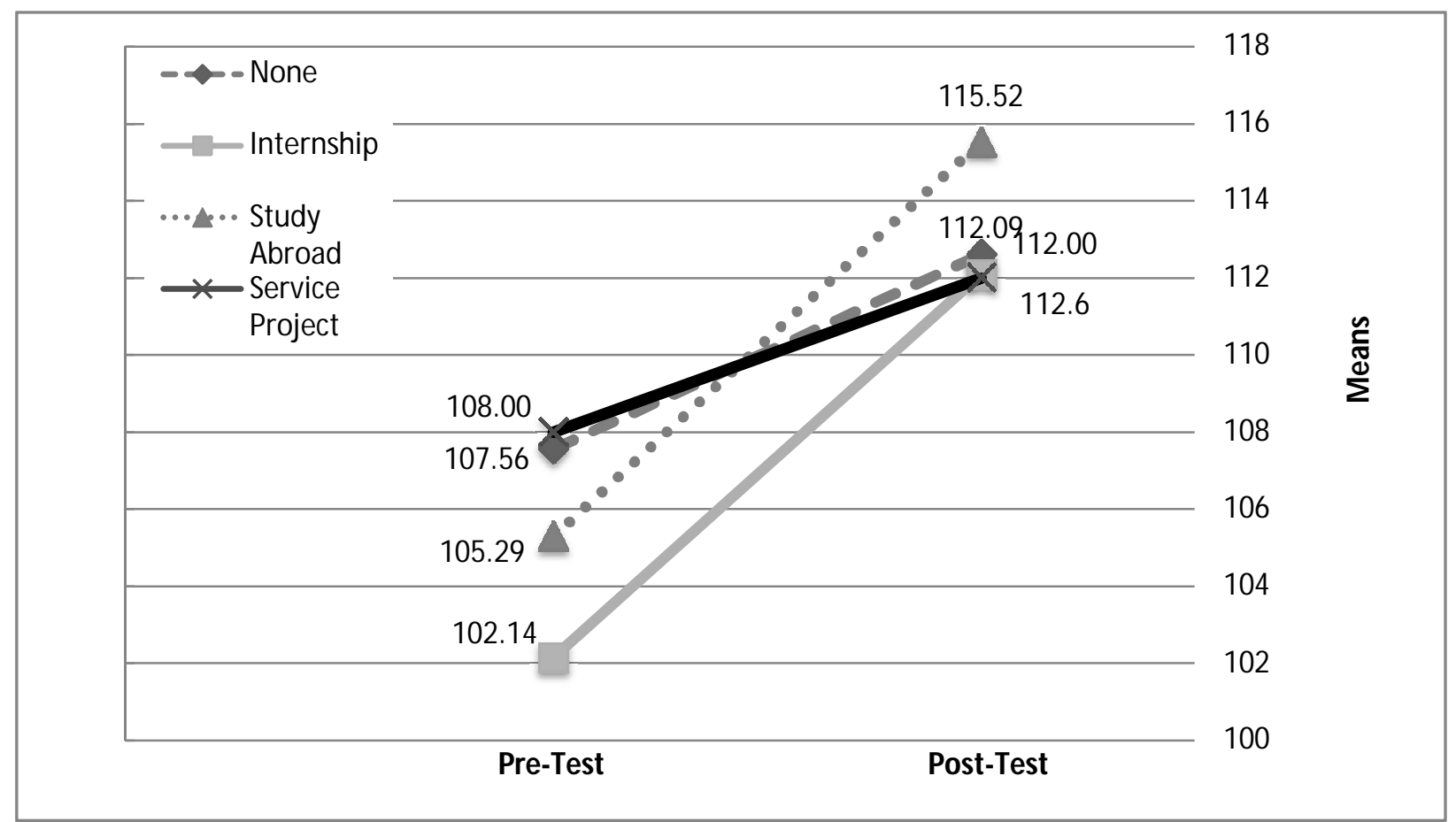

A continued examination of the post-test scores for LP3, Enabling Others to Act showed participants of the Study Abroad trips had notably higher results than those participating in no Experiential Learning Opportunities or those participating in Internships or Service Projects (Figure 6). This is of special note, since previous results have suggested that LP1, Challenging the Process, LP2, Inspiring a Shared Vision, LP4, Modeling the Way, and LP5, Encouraging the Heart have shown statistically significant gains or toward significance for participants. While the behaviors associated with LP3, Enabling Others to Act have not shown statistically significant gains, Study 
Abroad trips have demonstrated to be a valuable experiential learning opportunity as it relates to Enabling Others to Act.

Figure 6

LP3, Enabling Others to Act for Experiential Learning Opportunity (SLPI - Self)

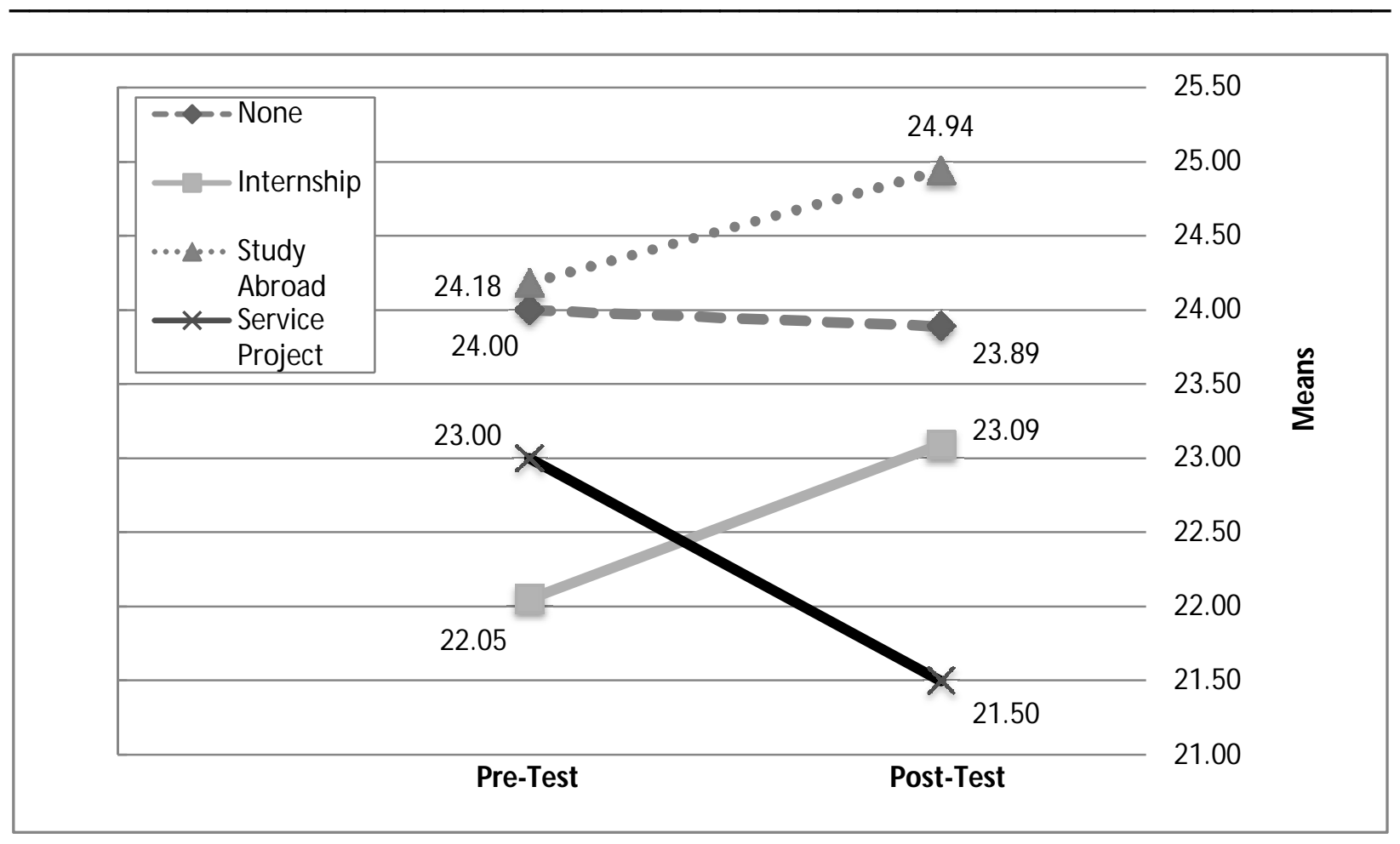

\section{SLPI - observer results.}

The results of the combined Experiential Learning Opportunity (None, Internship, Study Abroad, and Service Project) main effect resulted in statistical significance according to the SLPI - Observer. The total scores, according to the ANOVA for the SLPI - Observer, resulted in an $F$ value of 2.94 and a $p$ value of .045. Similarly, LP5, 
Encouraging the Heart, according to the ANOVA for the SLPI - Observer resulted in an $F$ value of 3.71 and a $p$ value of .020 (Tables $16 \& 17$ ). However, LP2, Inspiring a Shared Vision, LP3, Enabling Others to Act, and LP4, Modeling the way showed no statistical significance according to the SLPI - Observer. 
Table 16

Experiential Learning and the Pre-Test and Post-Test Scores on the SLPI - Observer

Total Scores

Experiential Learning (None, Internship, Study Abroad, Svs. Proj.)

Occasion (Pre - Post)

Interaction (Experiential Learning $x$ Occasion)

$\begin{array}{lll}d f & F & p\end{array}$

$p$

$3 \quad 2.94 \quad .045^{\star}$

$\begin{array}{lll}1 & .872 \quad .356\end{array}$

$\begin{array}{lll}3 & .812 \quad .495\end{array}$

LP1, Challenging the Process

$\begin{array}{llll}\text { Experiential Learning (None, Internship, Study Abroad, Svs. Proj.) } & 3 & 2.77 & .055 @ \\ \text { Occasion (Pre - Post) } & 1 & 2.29 & .138\end{array}$

Interaction (Experiential Learning x Occasion) $\quad 3 \quad 1.62 \quad .200$

LP2, Inspiring a Shared Vision

Experiential Learning (None, Internship, Study Abroad, Svs. Proj.) $\quad 3 \quad 1.95 \quad .138$

Occasion (Pre - Post)

$\begin{array}{lll}1 & 1.53 & .223\end{array}$

Interaction (Experiential Learning $x$ Occasion)

$3 \quad 2.19$

.106

LP3, Enabling Others to Act

Experiential Learning (None, Internship, Study Abroad, Svs. Proj.)

Occasion (Pre - Post)

Interaction (Experiential Learning x Occasion)

$3 \quad .614$

.610

$1 \quad .155$

.696

$3 \quad .295 \quad .829$

LP4, Modeling the Way

Experiential Learning (None, Internship, Study Abroad, Svs. Proj.) $\quad 3 \quad 2.03 \quad .126$

Occasion (Pre - Post)

$1 \quad 1.45$

.235

Interaction (Experiential Learning $x$ Occasion)

$3 \quad .914$

.443

LP5, Encouraging the Heart

Experiential Learning (None, Internship, Study Abroad, Svs. Proj.) $\quad \begin{array}{llll}3 & 3.71 & .020^{*}\end{array}$

Occasion (Pre - Post)

$\begin{array}{lll}1 & .352 & .557 \\ 3 & 2.02 & .130\end{array}$

Interaction (Experiential Learning $x$ Occasion)

$3 \quad 2.02 \quad .130$

${ }^{*} p<.05 \quad{ }^{* *} p<.01 \quad @ p<.10$ (Trend) 
Table 17

Experiential Learning and the Means \& Standard Deviations on the SLPI - Observer

\begin{tabular}{|c|c|c|c|}
\hline \multirow{2}{*}{ Total } & \multicolumn{2}{|c|}{ Pre-Test Mean (SD) } & \multirow{2}{*}{$\begin{array}{c}\text { Post-Test Mean (SD) } \\
\begin{array}{c}110.04(15.4) \\
122.92(10.9) \\
119.13(9.1) \\
131.65(.80)\end{array}\end{array}$} \\
\hline & $\begin{array}{l}\text { None } \\
\text { Internship } \\
\text { Study Abroad } \\
\text { Service Project }\end{array}$ & $\begin{array}{l}109.64(20.7) \\
119.40(11.6) \\
122.18(11.8) \\
119.85(.07)\end{array}$ & \\
\hline LP1, C & $\begin{array}{l}\text { Iging the Process } \\
\text { None } \\
\text { Internship } \\
\text { Study Abroad } \\
\text { Service Project }\end{array}$ & $\begin{array}{l}21.51(5.5) \\
23.02(2.2) \\
23.41(2.7) \\
23.60(.74)\end{array}$ & $\begin{array}{l}21.31(3.5) \\
24.82(2.4) \\
22.99(2.3) \\
27.15(1.8)\end{array}$ \\
\hline LP2, In & $\begin{array}{l}\text { g a Shared Visior } \\
\text { None } \\
\text { Internship } \\
\text { Study Abroad } \\
\text { Service Project }\end{array}$ & $\begin{array}{l}21.79(5.1) \\
23.42(2.4) \\
24.59(3.1) \\
23.25(1.2)\end{array}$ & $\begin{array}{l}22.10(2.6) \\
24.65(2.4) \\
23.15(2.5) \\
27.00(.92)\end{array}$ \\
\hline LP3, E & $\begin{array}{l}\text { Ig Others to Act } \\
\text { None } \\
\text { Internship } \\
\text { Study Abroad } \\
\text { Service Project }\end{array}$ & $\begin{array}{l}24.67(3.3) \\
25.61(2.4) \\
25.58(2.4) \\
23.90(.71)\end{array}$ & $\begin{array}{l}24.21(4.1) \\
25.44(3.1) \\
25.97(1.9) \\
25.10(2.5)\end{array}$ \\
\hline LP4, M & $\begin{array}{l}\text { g the Way } \\
\text { None } \\
\text { Internship } \\
\text { Study Abroad } \\
\text { Service Project }\end{array}$ & $\begin{array}{l}21.79(5.6) \\
23.62(2.2) \\
24.21(2.8) \\
24.50(.70)\end{array}$ & $\begin{array}{l}22.46(2.8) \\
24.79(2.8) \\
23.58(2.2) \\
27.05(.21)\end{array}$ \\
\hline LP5, E & $\begin{array}{l}\text { aging the Heart } \\
\text { None } \\
\text { Internship } \\
\text { Study Abroad } \\
\text { Service Project }\end{array}$ & $\begin{array}{l}23.31(3.3) \\
24.22(2.6) \\
24.63(2.8) \\
24.25(1.5)\end{array}$ & $\begin{array}{l}20.31(4.4) \\
24.90(2.3) \\
23.36(2.3) \\
25.85(1.3)\end{array}$ \\
\hline
\end{tabular}




\section{Summary}

As probed through Research Question One, participants demonstrated significant gains on the SLPI - Self pre-test and post test totals, and in three of the five leadership dimensions (LP1, Challenging the Process, LP2, Inspiring a Shared Vision, and LP4, Modeling the Way). In addition, LP5, Encouraging the Heart trended toward significance according to the SLPI - Self.

The data for Research Question Two revealed that female and male participants only demonstrated statistically significant gains according to the SLPI - Self between the interaction of pre-test and post-test scores and gender in LP3, Enabling Others to Act. Otherwise no statistical significance could be found in the relationship between Gender and the pre-test and post-test scores of the SLPI - Self or SLPI - Observer. However, the pre-test to post-test main effects according to the SLPI - Self noted statistical significance for Total Scores, LP1, Challenging the Process, LP2, Inspiring a Shared Vision, and LP3, Enabling Others to Act. These results matched the findings for Research Question One.

No statistical data could be calculated for Research Question Three due to the low sample size for the racial population. The data from Research Question Four revealed that leadership majors, minors, or certificate of leadership participants did not demonstrate significant gains through the interaction of type of McDonough Leadership scholar and the pre and post-test scores on any of the leadership practices in either the SLPI- Self or the SLPI- Observer. However, the pre-test to post-test main effects according to the SLPI - Self noted statistical significance for Total Scores, LP1, Challenging the Process, LP2, Inspiring a Shared Vision, and LP3, Enabling Others to 
Act. These results matched the findings for Research Question One. In addition, the pre-test to post-test main effect for LP5, Encouraging the Heart showed statistical significance while the $t$-Test in Research Question One showed only a trend toward significance.

For Research Question Five, data indicated no significant differences in the interaction between experiential learning groups (None, Internship, Study Abroad, or Service Project) and the pre - and post-test results in total score or any of the leadership practices according to either the SLPI - Self or SLPI - Observer. However, the pre-test to post-test main effects according to the SLPI - Self noted statistical significance for Total Scores, LP1, Challenging the Process, LP2, Inspiring a Shared Vision, and LP3, Enabling Others to Act. These results matched the findings for Research Question One.

Chapter 5 describes conclusions based upon the analysis of the major findings relevant to leadership behaviors of the participants. Furthermore, recommendations for practice and further research studies are also introduced. 


\section{Chapter Five}

\section{Discussion}

This chapter develops conclusions based upon the major findings relevant to the relationship between participation in Marietta College's McDonough Leadership program and the leadership development of college students. The conclusions are grouped according to the research questions to which they apply. Recommendations for practice and further research studies are also introduced.

\section{Conclusions}

Research Question One: After participating in the McDonough leadership program at Marietta College, do college students demonstrate significant gains in the development of leadership behaviors as measured by the SLPI - Self and SLPI - Observer, according to the five leadership dimensions of Modeling the Way, Inspiring a Shared Vision, Challenging the Process, Enabling Others to Act, and Encouraging the Heart?

Conclusions pertaining to Research Question 1 are based on results from the paired samples t-tests that reveal statistically significant gains on the post-test, using a level of $p<.01$ and $p<.05$, for the total scores and each of the five leadership practices and associated behaviors that form the foundation of the SLPI - Self. According to Kouzes and Posner, The SLPI is designed to measure the extent to which the student participant actually engages in the specific leadership behaviors (2002). Leadership participants indicated significant growth on the total scores and LP1, Challenging the Process, LP2, Inspiring a Shared Vision, and LP4, Modeling the Way, according to the SLPI - Self. In addition, LP5, Encouraging the Heart, trended toward significance.

The overall increase in post-test gains for four of the five leadership practices reflect the characteristics that define transformational leadership, in that leaders should demonstrate the ability to inspire a vision by mobilizing the commitments of others, 
challenging the status quo, modeling appropriate behaviors, and showing appreciation for individual excellence (Kouzes \& Posner, 2007; Wilcox, 2004b).

Therefore, the specific gains in learning suggest an increase in the general transformational leadership skills of participants in Marietta College's McDonough Leadership program. Further, the overall gains by the total population of the study ( $N=$ 50) reinforce the limited research existing which suggested that leadership development programs like that at Marietta College have been successful at developing short-term and long-term positive outcomes (Zimmerman-Oster \& Burkhardt, 1999).

The leadership practices with the highest pre- to post gains were LP1, Challenging the Process and LP2, Inspiring a Shared Vision, and reflects the importance of seeking innovative ways to improve and to develop a "big picture" view for an organization. The behaviors associated with these practices include (1) envisioning the future and (2) enlisting others (Kouzes \& Posner, 2007). The results may indicate characteristics of effective leadership in setting certain goals, plans, and objectives, as well as effectively communicating a vision for future initiatives. The results may also reinforce Hackman \& Johnson's (2004) position that "the presence of a shared and meaningful vision is a central component of effective leadership" (p. 13). The findings parallel other research which has suggested, unlike traditional interpretations of leadership, students who involve themselves in leadership training and education programs can increase their skills and knowledge by the mere participation in these activities (Wilcox, 2004b; Zimmerman-Oster \& Burkhardt, 2001).

The findings of this study also align with a qualitative study that showed a significant gain in the students' leadership behaviors after participating in Marietta 
College's McDonough Leadership program (Scott, 2007). Additionally, the findings of the current study concur with the belief that every student has the potential to lead and colleges and universities can develop this potential (Wilcox, 2004b).

In addition, the trending toward statistical significance for LP5, Encouraging the Heart, may show that celebrating accomplishments and communicating real purpose and meaning is a key component to the leadership development efforts of Marietta College's McDonough Leadership program. The concepts of positive feedback and the recognition of behaviors align with Marietta College's mission and values and are central to the core teachings of the McDonough Leadership center. Although, LP5, Encouraging the Heart only showed a trend toward statistical significance, I believe the results of this study showed a positive correlation between this leadership practice and the McDonough Leadership program.

One can conclude that LP3, Enabling Others to Act, is not developed significantly among students participating in Marietta College's McDonough Leadership Program. Kouzes and Posner (2007) suggested that one of the more difficult things to teach leaders is the concept that "grand dreams don't become significant realities through the actions of a single person" (p. 20). Leadership requires a team effort, and leaders should foster collaboration and build trust. These characteristics of leadership seem to be missing from the curriculum of Marietta College's McDonough Leadership program.

\section{Research Question Two: As measured by the SLPI - Self and SLPI - Observer, is there a statistically significant difference in the development of leadership behaviors by gender after participating in the McDonough leadership program at Marietta College?}

Conclusions pertaining to research question two involving gender are difficult to ascertain. While the results for the total scores and for LP1, Challenging the Way, and 
for LP2, Inspiring a Shared Vision support the results from the t-test in Research Question One, there is little relationship shown between gender and the results from the SLPI - Self or SLPI - Observer. The only relationship found is the within subjects results from pre-test to post-test for Encouraging the Heart according to the SLPI - Self.

These results are consistent with other research findings throughout the last 15 years that conclude that female leadership is characterized by the following: (1) use of a more participatory style; (2) emphasis on collective rather than individualistic; (3) encouragement of reciprocity; and (4) emphasis on empowerment (Kezar \& Moriarty, 2000; Wilcox, 2004b). Although the findings of this research study reveal that gender is associated with only the leadership practice of Encouraging the Heart, there is support for the need to continue examining the gender variable, according to Kouzes and Posner (2002).

To examine differences between pre- and post-test scores within each gender (female and male), a mixed measures ANOVA showed no statistically significant differences for either of the gender groups on the total scores or four of the five leadership practices. This suggests that gender is not relevant to the overall development of leadership behaviors at Marietta College's McDonough Leadership program.

It is important to note that an interaction between Gender and the pre-test and post-test results was shown for LP3, Enabling Others to Act, according to the SLPI Self. Further examination, showed that while males increased dramatically from pre-test to post-test, results for females showed little growth. Therefore, male students are 
developing behaviors associated with LP3, Enabling Others to Act at statistically significantly more than females.

In addition, the results for the within subjects comparison of LP5, Encouraging the Heart showed statistically significant gains in the main effect of gender. This suggests that students are developing behaviors associated with Encouraging the Heart as participants of Marietta College's McDonough Leadership program. Further examination, however, showed that females gained at a statistically significant higher rate than male students. These particular findings are somewhat surprising because previous research has found that women's leadership tends to use more of an interpersonal style as well as more of an emphasis on empowering, both of which point to skills addressed in LP2, Inspiring a Shared Vision (Kezar \& Moriarty, 2000).

\section{Research Question Three: As measured by the SLPI - Self and SLPI - Observer, is there a statistically significant difference in the development of leadership behaviors by race after participating in the McDonough leadership program at Marietta College?}

Unfortunately, the sample size representing race at Marietta College's McDonough leadership program was too small to discern any valuable statistical data. The limited comparison numbers in the sample were not surprising given the racial and ethnic composition of Marietta College and the students who participate in the McDonough Leadership program. 


\section{Research Question Four: As measured by the SLPI - Self and SLPI - Observer, is there a statistically significant difference in the development of leadership behaviors by the type of McDonough Scholar including International Leadership Studies major, Leadership Studies minor, and Certificate of Leadership Studies after participating in the McDonough leadership program at Marietta College?}

According to results of the mixed methods ANOVA, no gains were revealed in total scores or any of the leadership practices according to either the SLPI - Self or SLPI - Observer. However, caution should be taken with the conclusion because of the overall sample size $(N=50)$ and the sample size for students majoring in International Leadership Studies $(N=7)$.

One conclusion that could be made, however, is that students, who participate in the Certificate of Leadership program, improve in their overall leadership development at similar levels to those students who minor in Leadership Studies and major in International Leadership Studies. This is not surprising due to the fact that there is significant overlap in the faculty who teach these programs. In addition, the results suggest that students who participate in the McDonough Leadership program, regardless of the type of McDonough scholar, improve at a consistent rate in each of the leadership practices according to the SLPI - Self and SLPI - Observer.

Further examination, reveals other interesting results. According to the SLPI Self results, students majoring in International Leadership Studies and pursuing a Certificate of Leadership Studies at Marietta College showed significant gains in LP3, Enabling Others to Act. However, students who minored in Leadership Studies only showed nominal gains. Conclusions are difficult to make due to the low sample size overall and that of students who majored in Leadership Studies $(N=7)$. 
Also of note, participant results for certificate of leadership studies students routinely finished below participant results from students majoring in International Leadership Studies in total scores and most leadership practices according to the SLPI - Self. However, behaviors associated with the leadership practice of Enabling Others to Act were developed at a significantly higher rate among certificate of leadership studies than students who majored in International Leadership studies. These results are surprising due to the fact that one of the behaviors associated with Enabling Others to Act is teamwork. Several requirements which are part of the curriculum for students majoring in International Leadership studies are intended to foster collaboration and trust. Caution should be taken, however, in making any definitive conclusions due to the small sample size for students majoring in International Leadership Studies as noted above.
Research Question Five: As measured by the SLPI - Self and SLPI - Observer, is there a statistically significant difference in the development of leadership behaviors by the type of experiential learning opportunity including internship, study abroad, and service project after participating in the McDonough leadership program at Marietta College?

According to the results of the mixed methods ANOVA, no statistical gains were revealed in total scores or any of the leadership practices according to the SLPI - Self. However, the SLPI - Observer noted statistical significance in the within subjects comparison for Experiential Learning for the Total Scores and LP5, Encouraging the Heart. In addition, there was a trend toward statistical significance in the leadership practice Challenging the Process.

When examining the total score improvements from students who attended an internship or study abroad trip as part of Marietta College's McDonough Leadership 
program, statistically significant increases were noted. Therefore, students who participated in those types of experiential learning opportunities, showed much more dramatic increases in pre- and post-test scores compared to students who did not.

This would seem to contradict some of the results from Research Question Four, in that students participating in the Certificate of Leadership Studies program showed higher gains from pre-test to post-test than students majoring in International Leadership Studies in the leadership practice Enabling Others to Act. This is surprising since students participating in the Certificate of Leadership Studies do not have the same team oriented requirements of International Leadership Study majors. However, further examination of the results notes that a significant number of students, who participated in the Study Abroad experiential learning opportunity, were students receiving a Certificate of Leadership Studies.

Therefore, one conclusion is that an essential component of developing behaviors associated with the leadership practice Enabling Others to Act is experiential learning in general and the Study Abroad trip in particular. This is an important conclusion, because as was noted earlier the only leadership practice that was not statistically significant or trending toward significance was LP3, Enabling Others to Act. While conclusions are difficult to make due to the overall low sample size and that of students who did not participate in any leadership opportunity $(N=9)$ and students participating in service projects $(N=2)$, this conclusion does support other research done on the effects of experiential learning on leadership development. 


\section{Recommendations}

\section{Recommendations for practice.}

While this study had a relatively low sample size $(N=50)$, this study showed impressive gains for students who participated in Marietta College's McDonough Leadership program. Since participants gained significantly in the total scores and four of the leadership practices (Challenging the Process, Inspiring a Shared Vision, Modeling the Way, and Encouraging the Heart), one recommendation is for an additional emphasis to be placed on improving the McDonough Leadership Program curriculum as it relates to LP3, Enabling Others to Act.

Research has shown, and the results of this study agreed, that behaviors associated with LP3, Enabling Others to Act and LP5, Encouraging the Heart are often the most difficult to develop as leaders. Students can be taught skills and behaviors related to Challenging the Process, Inspiring a Shared Vision and Modeling the way through academic and extra-curricular means. It is more challenging to develop skills associated with "treating others with respect" and "supporting and showing appreciation for others". Therefore more emphasis needs to be placed on how skills and behaviors associated with LP3 and LP5 can be developed through the McDonough Leadership programs curriculum.

Another area of emphasis should include additional experiential learning opportunities. The results of this survey suggest that all students participating in the McDonough Leadership program should attend the Study Abroad trip, since scores were higher for that experiential learning opportunity compared to the other experiences. 
In addition, considering the growing importance of the ability to make leadershipbased decisions as society advances in the new century it seems imperative that all institutions of higher education begin to develop leadership initiatives like that at Marietta College. This coupled with the transformational focus of the contemporary paradigm of leadership suggests leadership programs like Marietta College should continue to emphasize the leadership practices developed by Kouzes and Posner (2007).

Further, the research from this study reinforces the implementation of leadership development programs which combine academic rigor, experiential learning, selfreflection, and opportunities for team participation in service learning projects. These common elements of the McDonough Leadership program course emerged as directly influencing the development of positive leadership behaviors of college students. These elements also closely align with the transformational characteristics of Kouzes and Posner's Leadership Challenge (2007). One suggestion might be to more intentionally integrate into the McDonough Leadership curriculum the behaviors and skills associated with each of the leadership practices.

\section{Recommendations for further research.}

1. Continued research at Marietta College is needed in order to improve the overall sample size of this research. Since Marietta College only began utilizing the SLPI - Self and SLPI - Observer four years ago, additional research will be invaluable to better understand the development of leadership behaviors among students participating in Marietta College's McDonough Leadership program. This follow up study should be a 
mixed methods study and should incorporate a study of the curriculum and the role that experiential learning plays at Marietta College's McDonough Leadership program.

2. A control group should be included into the study which compares results from (a) students participating in Marietta College's McDonough Leadership program and (b) students at Marietta College but not participating in the McDonough Leadership program. All college students should show some level of growth in leadership development from freshman to senior years; however, it would be important to see those results compared to participants in Marietta College's McDonough Leadership program in order to better understand the relationship between the program and growth in leadership skills.

3. Additional studies should be done to compare the leadership development of Marietta College students with other leadership development programs at other institutions. A longitudinal study among a variety of national leadership programs utilizing Kouzes and Posner's Student Leadership Practices Inventory would be very valuable and would help administrators better understand what components of leadership development programs more effectively develop leaders.

4. While a qualitative study of Marietta College's McDonough Leadership program has been done (Scott, 2007), additional qualitative research is needed. Since this study was done to examine the development of leadership behaviors from freshman to senior year, it might be valuable to do a qualitative study among graduates to look back at their experiences at Marietta College's McDonough Leadership program and the behaviors and skills they gained. This would also allow administrators to better understand which leadership behaviors alumni feel are most essential once they are placed in leadership 
positions after college. Additional quantitative research can be implemented with graduates as well. A mixed-methods research project may be the best way to ensure the best results.

5. An attempt should be made to study diverse student populations by race and ethnicity, since this study did not have an adequate enough sample of non-Caucasian participants $(N=2)$.

6. Additional studies should more thoroughly examine the role experiential learning opportunities like Study Abroad trips and Internships play in leadership development. A qualitative study could be done with Marietta College students before and after they participate in a Study Abroad trip or Internship. 


\section{References}

Adair, J. (1989). Great leaders. Surrey, England: The Talbot Adair Press.

Allen, S.J. (2006). An exploration of theories of action in leadership development: A case study. (Doctoral dissertation, Antioch University, 2006). Retrieved June 14, 2010 from http://etd.ohiolink.edu/view.cgi?acc_num=antioch1141832898.

Argyris, C. (1997). Learning and teaching: A theory of action perspective. Journal of Management Education, 21(1), 9-26.

Argyris, C., \& Schön, D. (1978). Theory in practice: Increasing professional effectiveness. San Francisco: Jossey-Bass.

Ask.Com. (2010). Marietta College. Retrieved on December 23, 2010 from http://www.ask.com/wiki/Marietta_College.

Astin, A.W. (1985). Achieving educational excellence: A critical assessment of priorities and practices in higher education. San Francisco: Jossey-Bass.

Astin, A.W. (1993). What matters most in college: Four critical years revisited. San Francisco: Jossey-Bass.

Astin, A.W. (1997). Liberal education and democracy: The case for pragmatism. Liberal Education, 83(4), 4.

Astin, H.S., \& Cress, C.M. (1998). The impact of leadership programs on student development. Higher Education Research Institute, Los Angeles: Technical Report to W.K. Kellogg Foundation (November 1998).

Austin, M.L., Martin, B., Mittelstaedt, R., Schanning, K., \& Ogle, D. Outdoor orientation program effects: Sense of place and social benefits. Journal of Experiential Education, 31(3), 435-439. 
Avolio, B. (2004). Examining the full range model of leadership: Looking back to transform forward. In D. Day, S. Zaccaro, \& S. Halpin (Eds.), Leader development for transforming organizations: Growing leaders for tomorrow (pp. 71-98). Mahwah, New Jersey: Lawrence Erlbaum Associates.

Avolio, B. (2005). Leadership development in balance. Mahwah, New Jersey: Lawrence Erlbaum Associates.

Avolio, B.J., \& Bass, B.M. (2002).Developing Potential across a full range of leadership: Cases on transactional and transformational leadership. Mahwah, NJ: Lawrence Erlbaum Associates.

Bass, B.M. (1985). Leadership and performance beyond expectation. New York: Free Press.

Bass, B.M., \& Avolio, B.J. (1990). The implications of transactional and transformational leadership for individual, team, and organizational development. Research in Organizational Change and Development, 4(1), 231-272.

Bass, B.M. (1991). Bass and Stogdill's handbook of leadership: A survey of theory and research. New York: Free Press.

Bass, B.M., \& Avolio, B.J. (1994). Improving organizational effectiveness through transformational leadership. Thousand Oaks, CA: Sage.

Bass, B.M., \& Steidlmeier, P. (1999). Ethics, character, and authentic transformational leadership behavior. Leadership Quarterly, 10(2), 181-217.

Becker, H.S. (1985). Outsiders: Studies in the sociology of deviance. New York: Free Press.

Benne, K.D., \& Sheats, P. (1948). Functional roles of group members. Journal of 
Social Issues, 4(2), 41-49.

Bennis, W.G., \& Goldsmith, J. (1997). Learning to lead: A workbook on becoming a leader (Rev. ed.). Reading, MA: Addison-Wesley.

Bennis, W.G., \& Nanus, B. (1997). Leaders: The strategies for taking charge (2nd ed.). New York: Harper Business.

Block, P. (1993). Stewardship: Choosing service over self-interest. San Francisco: Berrett-Noehler.

Brembeck, W.L., \& Howell, W.S. (1952). Persuasion. New York: Cambridge University Press.

Brown, P. C. (1994). Liberal education for leadership. Liberal Education, 80(2), 44-48.

Burns, J. (1978). Leadership. New York: Harper \& Row.

Burns, J. M. (2003). Transforming leadership. New York: Grove Press.

Burns, T., \& Stalker, G.M. (1961).The management of innovation. London: Tavistock Publications.

Campus Compact. (2007). 2006 Service statistics: Highlights and trends of Campus Compact's annual membership survey. Providence, RI: Campus Compact.

Cason, D., \& Gillis, H.L. (1994). A meta-analysis of adventure programming with adolescents. Journal of Experiential Education, 17(1), 40-47.

Cherrey, C., \& Isgar, R. (1998). Leadership education in the context of the new millennium. Concepts \& Connections, 6(1), 5-10.

Ciulla, J.B. (1998). Leadership and the problem of bogus empowerment. In J.B. Ciulla (Ed.), Leadership and ethics working papers: The Kellogg leadership studies project (pp. 43-67). College Park, Maryland: University of Maryland Press. 
Clifford, J. S., Boufal, M. M., \& Kurtz, J. E. (2004). Personality traits and critical thinking skills in college students: Empirical tests of a two-factor theory. Assessment, 11(1), 169-176.

Creswell, J.W. (1998). Qualitative inquiry and research design: Choosing among five traditions. Thousand Oaks, CA: Sage.

Coleman, J.S. (1979). Experiential learning and information assimilation: Toward an appropriate mix. Journal of Experiential Education, 2(1), 6-9.

Connaughton, S.L., Lawrence, F.L., \& Ruben, B.D. (2003). Leadership development as a systematic and multidisciplinary enterprise. Journal of Education for Business, 79(1), 46-51.

Council for the Advancement of Standards in Higher Education. (2006). CAS professional standards for higher education (6th ed.). Washington, DC: Council for the Advancement of Standards in Higher Education. Retrieved June 13, 2010 from http://www.cas.edu/getpdf.cfm?PDF=E86F4088-052E-0966ADCB25F2A9FE7A70.

Covey, S. (1989). The Seven Habits of Highly Effective People. New York: Simon and Schuster.

Davis-Berman, J.L., \& Berman, D. (1996). Using the wilderness to facilitate adjustment to college: An updated description of wilderness orientation programs. Journal of Experiential Education, 19(1), 22-28.

Day, D. (2001). Leadership development: A review in context. Leadership Quarterly, 11(4), 581-613.

Day, D. (2004). Leadership development. In G. Goethals, G. Sorenson, \& J. Burns 
(Eds.), The Encyclopedia of Leadership, volume 2 (p. 840-844). Thousand Oaks, CA: Sage.

DePree, M. (1989). Leadership is an art. New York: Doubleday.

DePree, M. (1992). Leaders' Leaders. In M. DePree, Leadership Jazz (pp. 93-108). New York: Doubleday

Dewey, J. (1997). Experience and education. New York: Simon and Schuster.

Doh, J.P. (2003). Can leadership be taught? Perspectives from management educators. Academy of Learning and Management Education, 2(1), 54-67.

Donaldson, G.W., \& Vinson, R. (1979). William James: Philosophical father of experienced-based education. Journal of Experiential Education, 2(2), 6-8.

Doyle, W.E. (1981). An outdoor-challenge experience and the effective development of college students. (Doctoral dissertation, University of Massachusetts, 1981). Dissertation Abstracts International, 42(3), A1022-1023.

Drucker, P.F. (1999). Management challenges for the $21^{\text {st }}$ century. New York: Harper Collins Publishers.

Fiedler, R.E. (1967). A theory of leadership effectiveness. New York: McGraw Hill. Flannery, D. (1999). Service learning: A vehicle for developing cultural competence in health education. American Journal of Health and Behavior, 23(5), 323-313.

Ford, P. (1981). Principles and practices of outdoor / environmental education. New York: Wiley.

Gall, M., Gall, J., \& Borg, W. (2003). Educational Research: An Introduction (7th ed.). Boston: Pearson Education.

Gardner, H. (1995). Leading minds: An anatomy of leadership. New York: Basic Books. 
Gardner, J.W. (1990). On leadership. New York: The Free Press.

Gass, M.A. (1985). Programming the transfer of learning in adventure education. Journal of Experiential Education, 8(3), 18-24.

Gass, M.A., Garvey, D.E., \& Sugerman, D.A. (2003).The long-term effect of a first year student wilderness orientation program. The Journal of Experiential Education, 26(1), 34-40.

Gilchrist, L.D., Schinke, S.P., \& Maxwell, J.S. (1987). Life skills counselling for preventing problems in adolescence. Journal of Social Service Research, 10(2/3/4), 73-84.

Goleman, D., Boyatzis, R., \& McKee, A. (2002). Primal leadership: Realizing the power of emotional intelligence. Boston: Harvard Business School Press.

Graen, G., \& Uhl-Bien, M. (1995). Relationship-based approach to leadership development of leader-member exchange (LMX) theory of leadership over 25 years: Applying a multi-level, multi-domain perspective. Leadership Quarterly, 6(2), 219-247.

Graen, G. (1976). Role making processes within complex organizations. In M.D. Dunnette (Ed.), Handbook of industrial and organizational psychology (pp.12011245). Chicago: Rand McNally.

Graham, J.W. (1991). Servant-leadership in organizations: Inspirational and moral. Leadership Quarterly, 2(2), 105-119.

Greenleaf, R.K. (1977). Servant leadership: A journey into the nature of legitimate power and greatness. New York: Paulist.

Gunn, B. (2000). Can leadership be taught? Strategic Finance, 82(6), 14-15. 
Hackman, M. Z., \& Johnson, C. E. (2004). Leadership: A communication perspective (4th Ed.). Long Grove, IL: Waveland Press.

Hans, T. (2000). A meta-analysis of the effects of adventure programming on locus of control. Journal of Contemporary Psychotherapy, 30(1), 33-60.

Hattie, J., Marsh, H., Neill, J.T., \& Richards, G. (1997). Adventure education and Outward Bound: Out-of-class experiences that make a lasting difference, Review of Educational Research, 67(1), 43-48.

Hazelbaker, C. (2006). The SWOT analysis: Simple, yet effective. Athletic Therapy Today, 11(6).53-55.

Heifetz, R. (1994). Leadership without easy answers. Massachusetts: Harvard University Press.

Hersey, P., \& Blanchard, K. (1996). Great ideas revisited: Revisiting the life-cycle theory of leadership. Training and Development, 50(1), 42-47.

Higgins, P. (2009). Into the big wide world: Sustainable experiential education for the $21^{\text {st }}$ century. Journal of Experiential Education, 32(1), 44-60.

Hinton, J.L., \& Jones, J.J. (2007). Study of self-efficacy in a freshman wilderness experience program: Measuring general versus specific gains. Journal of Experiential Education, 29(3), 382-385.

Hornyak, M. J., \& Page, D. (2004). Experiential learning: Introducing faculty and staff to a university leadership development program. Simulation \& Gaming, 35(1), 461475.

House, R.J., \& Mitchell, T.R. (1974). Path-goal theory of leadership. Contemporary Business, 3(1), 81-98. 
Howe, W., \& Freeman, F. (1997). Leadership education in American colleges and universities: An overview. Concepts \& Connections: A Newsletter for Leadership Educators, 5(2).

Huber, N. (2003). An experiential leadership approach for teaching tolerance for ambiguity. Journal of Education for Business, 79(1), 52-55.

Hunt, J.S. (1990). Philosophy of adventure education. In J.C. Miles \& S. Priest (Eds.), Adventure education (pp. 119-128). State College, PA: Venture.

Hutt, G.K. (2007). Experiential learning spaces: Hermetic transformational leadership for psychological safety, consciousness development and math anxiety related inferiority complex depotentiation. Retrieved May 1, 2007 from Ohio Link Website: http://rave/ohiolink.edu/etdc/view?acc_num=case1175892374 James, W. (1900). Talks to teachers and students. New York: Henry Holt \& Co. Jones, J.E., \& Pfieffer, J. (Eds.) (1980). The 1980 Annual Handbook for group facilitators. San Diego: Pfieffer and Company.

Jones, S.R., Lucas, N., \& NCLP Staff. (1994). Interview with Dr. James MacGregor Burns. Concepts \& Connections: A Newsletter for Leadership Educators, 2(2). Joplin, L. (1981). On defining experiential education. Journal of Experiential Education, $4(1), 17-20$.

Karnes, F.A., \& Stephens, K. (1999). Lead the way to leadership education. Education Digest, 64(8), 62-66.

Kearns, M.S. (2005). Retrieved on 1/4/2011 at http://www.leadership studies.com/lsw/definitions.htm. 
Kenny, D.A., \&Zaccaro, S.J. (1983). An estimate of variance due to traits in leadership. Journal of Applied Psychology, 68(4), 678-685.

Kezar, A., \& Moriarty, D. (2000).Expanding our understanding of student leadership development: A study exploring gender and ethnic identity. Journal of College Student Development, 41(1), 55-68.

Klint, K.A. (1991). New directions for inquiry into self-concept and adventure experiences. In J.C. Miles and S. Priest (Eds.), Adventure Education (pp. 163172). State College, PA: Venture.

Komives, S.R., Lucas, N., \& McMahon, T.R. (1998). Exploring leadership: For college students who want to make a difference. San Francisco: Jossey-Bass.

Kouzes J.M. \& Posner, B.Z. (1993). Credibility: How leaders gain and lose it, and why people demand it. San Francisco: Jossey-Bass.

Kouzes, J.M., \& Posner, B.Z. (2002). The leadership challenge (3rd ed.). San Francisco: Jossey-Bass.

Kouzes, J.M. \& Posner, B.Z. (2005a). Student leadership practices inventory: Self. San Francisco: Jossey-Bass.

Kouzes, J.M. \& Posner, B.Z. (2005b). Student leadership practices inventory: Observer. San Francisco: Jossey-Bass.

Kouzes, J.M. \& Posner, B.Z. (2007) The leadership challenge ( $4^{\text {th }}$ ed.). San Francisco: Jossey-Bass.

Kraft, R. (1985). Toward a theory of experiential learning. In R.J. Kraft \& M. Sakofs (Eds.), The theory of experiential education (pp. 4-35). Boulder, CO: Association for Experiential Education. 
Lappin, E. (2000). Outdoor education for behavior disordered students. Retrieved June 1, 2010, from http://www.kidsource.com/kidsource/content2/outdoor.education.ld.k12.3.html.

Lewin, K. (1935). A dynamic theory of personality. New York: McGraw Hill.

Lewin, K., \& Grabbe, P. (1945). Conduct, knowledge and acceptance of new values. Journal of Social Sciences, 2(1), 56-64.

Luckner, J.L., \& Nadler, R.S. (1997). Processing the experience: Strategies to enhance and generalize learning. Dubuque, IA: Kendall Hunt.

Lussier, R.N., \& Achua, C. (2001).Leadership: Theory, application, skill building. Cincinnati: South-Western College Publishing.

Macpherson, K. (1999). The development of critical thinking skills in undergraduate supervisory management units: Efficacy of student peer assessment. Assessment\& Evaluation in Higher Education, 24, 273-284.

Marietta College. (2006). McDonough leadership program: Information handbook. [Brochure]. Marietta, OH: Author.

Marietta College. (2011). Retrieved September 25, 2011 from http://www.marietta.edu/About/.

Marsh, H.W., Richards, G.E., \& Barnes, J. (1986). Multidimensional self concepts: The effect of participation in an Outward Bound program. Journal of Personality and Social Psychology, 50, 195-204.

Maxwell, J.C. (1993). Developing the leader within you. Nashville: Thomas Nelson Publishers. 
McCauley, C.D., \& Van Velsor, E. (Eds.). (2005). The center for creative leadership handbook of leadership development. San Francisco: Jossey-Bass.

McClelland, D.C., \& Burnham, D.H. (1976). Power is the great motivator. Harvard Business Review, 81(1), 117-125.

McClintock, C., Brannon D., \& S. Maynard-Moody. (1979). Applying the logic of sample surveys to qualitative case studies: The case cluster method. Administrative Science Quarterly, 24(4): 612-629.

McCorkle, J. (1998). The snipe hunt. In The Nature Conservancy (Ed.), Off the beaten path: Stories of place (pp. 59-74). New York: North Point Press.

McDonough Center for Leadership and Business at Marietta College. Retrieved May 5, 2007 from http://mcdonough.marietta.edu.

McNally, J.A., Gerras, S.J., \& Bullis, R.C. (1996).Teaching leadership at the U.S. Military Academy at West Point. Journal of Applied Behavioral Science, 32, 175188.

Merriam, S.B. (1985). The case study in educational research: A review of selected literature. Journal of Educational Thought, 19(3), 204-217.

Merriam, S.B. (1998). Qualitative research and case study application in education. San Francisco: Jossey-Bass.

Merriam, S.B., \& Caffarella, R.S. (1999). Learning in adulthood: A comprehensive guide. San Francisco: Jossey-Bass.

Mitchell, R.G. (1983). Mountain experience: The psychology and sociology of adventure. Chicago: University of Chicago Press. 
Miller, T. (Ed.) (1997). CAS: The book of professional standards for higher education (2nd ed.). Washington, DC: Council for the Advancement of Standards in Higher Education.

Milter, R.G., \& Stinson, J.E. (1995).Educating leaders for the new competitive environment. Retrieved January 10, 2007 from Ohio University Web site: http://www.ouwb.ohio.edu/this_is_ouwb/papers/paper2.htm

Morrill, R.L., \& Roush, J.A. (1991).Leadership education. National Forum, 71(1), 26-27. Neff, T.J., \& Citrin, J.M. (1999).Lessons from the top: The search for America's best business leaders. New York: Doubleday.

Neill, J.T. (2003). Reviewing and benchmarking adventure therapy outcomes: Applications of meta-analysis. Journal of Experiential Education, 25(3), 316-321. Ngai, S.S. (2006). Service learning, personal development, and social commitment: A case study of university students in Hong King. Adolescence, 41(161), 165-176.

Nirenberg, J. (2003). Toward leadership education that matters. Journal of Education for Business, 79(1), 6-10.

Northouse, P. (2007). Leadership: Theory and practice, 5th ed., Thousand Oaks, CA: Sage Publications.

Northouse, P. (2009). Introduction to leadership: Concepts and practice. Thousand Oaks: Sage.

Ohio History Central. (2010). Marietta College. Retrieved on December 23, 2010 from http://www.ohiohistorycentral.org/entry.php?rec=2163.

O'Neil, H., \& Fisher, Y. (2004). A technology to support leader development: 
Computer games. In D. Day, S. Zaccaro, \& S. Halpin (Eds.), Leader development for transforming organizations: Growing leaders for tomorrow (pp. 41-69).

Mahwah, New Jersey: Lawrence Erlbaum Associates.

Outward Bound. (2010a). Welcome to Outward Bound. Retrieved on June 15, 2010 from http://www.outwardbound.org/index.cfm/do/ind.about.

Outward Bound (2010b). Welcome to the Outward Bound USA Research. Retrieved on July 6, 2010 from http://research.outwardbound.org/.

Owen H., Hodgson, V., \& Gazzard, N. (2004). The leadership manual: Your complete practical guide for effective leadership. Norfolk, Great Britain: Biddles.

Patton, M.Q. (1997). Utilization-focused evaluation: The new century text. Thousand Oaks, CA: Sage.

Patton, M.Q. (2002). Qualitative research \& evaluation methods. ( $3^{\text {rd }}$ Ed.). Thousand Oaks, CA: Sage.

Paul, R.J. (2010). Napoleon Bonaparte's Guide to Leadership. Retrieved December 22, 2010 from http://potential2success.com/Napoleonbonaparteleadership.html.

Perruci, G. (2007, February). The 2006-2007 report to the McDonough advisory board. Paper presented at the meeting of the Advisory Board of the Bernard P. McDonough Center for Leadership and Business at Marietta College, Marietta, $\mathrm{OH}$.

Peters T.J., \& Waterman R.H. (1982). In search of excellence: Lessons from America's best-run companies. New York: Harper and Row.

Peters, T., \& Austin, N. (1985).A passion for excellence: The leadership difference. New York: Random House. 
Peters, T. (2002). Liberation Management. New York: Harper and Row.

Plante, T.G., Lackey, K., \& Hwang, J.Y. (2009). The impact of immersion trips on development of compassion among college students. Journal of Experiential Education, 32(1), 28-43.

Posner, B.Z., \& Brodsky, B. (1992). A leadership development Instrument for college students. Journal of College Student Development, 33(4), 231-237.

Posner, B.Z., \& Brodsky, B. (1993). The leadership practices of effective RA's. Journal of College Student Development, 34(4), 300-304.

Posner, B.Z., \& Brodsky, B. (1994). Leadership practices of effective student leaders: Gender makes no difference. NASPA Journal, 31(2), 113-120.

Posner, B.Z., \& Rosenberger, J. (1997). Orientation advisors are leaders too. NASPA Journal, 35(1), 46-56.

Posner, B.Z. (2004). A leadership development instrument for students: Updated. Journal of College Student Development, 45(4), 443-456.

Posner, B.Z. (2009). A longitudinal study examining changes in student's leadership behavior. Journal of College Student Development, 50(5), 551-563.

Posner, B.Z. (2010). Psychometric properties of the student leadership practices inventory. Retrieved June 14, 2010 from http://media.wiley.com/assets/2232/76/StudentLPIPsychometricProperties_2010. pdf.

Priest, S. (1986). Redefining outdoor education: A matter of many relationships. Journal of Environmental Education, 17(3), 13-15. 
Priest, S. (1992). Factor exploration and confirmation for the dimensions of an adventure experience. Journal of Leisure Research, 24(2), 127-139.

Priest, S., \& Gass, M. (2005). Effective leadership in adventure programming $\left(2^{\text {nd }}\right.$ ed. $)$. Champaign, IL: Human Kinetics.

Prince, H.T., II. (2001). Teaching leadership: A journey into the unknown. Concepts \& Connections: A Newsletter for Leadership Educators, 9(3).

Reichardt, C.S., \& Cook, T.D. (1979). Beyond qualitative versus quantitative methods. In T. D. Cook \& C. S. Reichardt (Eds.), Qualitative and quantitative methods in evaluation research (pp. 7-32). Thousand Oaks, CA: Sage.

Rhoades, J.S. (1972). The problem of individual change in Outward Bound: An application of change and transfer theory. (Doctoral dissertation, University of Massachusetts).Dissertation Abstracts International, 33(1), A4922.

Roberts, D.C. (1997).The changing look of leadership programs. Concepts \& Connections: A Newsletter for Leadership Educators, 5(2).

Rubens, D. (1999). Effort or performance: Keys to motivated learners in the outdoors. Horizons, 4(1), 26-28.

Sanger, M. (1997).Sense of place and education. Journal of Environmental Education, 29(1), 4-9.

Santrock, J.W. (1992). Life-span development. Dubuque, lowa: WC Brown.

Schwandt, T.A. (2001). Dictionary of qualitative inquiry (2nd ed.). Thousand Oaks, CA: Sage. 
Schwartz, S.W. (1994, August). A not so brief history of Bernard P. McDonough center for leadership and business at Marietta College. Paper presented to Marietta College faculty, Marietta, $\mathrm{OH}$.

Scott, C.G. (2007). Undergraduate Leadership Programs: A Case Study Analysis of Marietta College's McDonough Leadership Program. (Doctoral dissertation, Ohio University, 2007). Retrieved December 22, 2010fromhttp://etd.ohiolink.edu/view.cgi/Scott\%20Christopher\%20G.pdf?acc_nu $\mathrm{m}=$ ohiou1187296643.

Sheridan, P.T. (2004). Qualifications for wilderness trip leaders. Camping Magazine, $77(1), 38-43$.

Shooter, W., Sibthorp, J., \& Paisley, K. (2009). A closer look at the inner workings of adventure education: Building evidence-based practices. The Journal of Experiential Education, 32(1), 1-13.

Sibthorp, J., \& Arthur-Banning, S. (2004). Developing life effectiveness through adventure education: The roles of participant expectations, perceptions of empowerment, and learning relevance. Journal of Experiential Education, 27(1), $32-50$.

Sindell, M., \& Hoang, T. (2001).Leadership development. Alexandria, VA: ASTD.

Smith, T., \& Allison, P. (2006).Outdoor experiential leadership, Lake Geneva, WI: Racoon Institute Publications.

Stake, R. (1995). The art of case research. Thousand Oaks, CA: Sage Publications. Stremba, B., \& Bission, C. (Eds.) (2009). Teaching adventure education theory. Champaign, IL: Human Kinetics. 
Stodgill, R.M. (1948). Personal factors associated with leadership: Survey of literature. Journal of Psychology, 25(1), 35-71.

Stogdill, R.M. (1974). Handbook of leadership: A survey of the literature, New York: Free Press.

Sutton, R.I. (2002). When ignorance is bliss. Industrial Management, 44(1), 8-12.

Swiderski, M. (1987). Soft and conceptual skills: The often overlooked components of outdoor leadership. In G. Robb (Ed.) Proceedings of the coalition for education in the outdoor research symposium (pp. 29-36). Martinsville, IN: Bradford Woods Center for Outdoor Education.

Vaske, J.J., \& Kobrin, K.C. (2001). Place attachment and environmentally responsible education. The Journal of Environmental Education, 32(4), 16-21.

Vicere, A., \& Fulmer, R. (1996). Leadership by design. Boston, Massachusetts: Harvard Business School Press.

Walsh, V., \& Goblins, G. (1976). The exploration of the Outward Bound process. Denver: Colorado Outward Bound School.

W. K. Kellogg Foundation (1999). Leadership in the making: Impact and insights from leadership development programs in U.S. colleges and universities. Battle Creek, MI: W.K. Kellogg Foundation.

Wilcox, B.L. (2004a). Mentoring and self-mentoring: coaching ourselves and others. English Leadership Quarterly, 27(2), 1-2.

Wilcox, B.L. (2004b). Leadership development of community college students: Does participation in the Phi Theta Kappa leadership development studies course have 
an effect on the development of leadership behaviors? (Doctoral Dissertation, West Virginia University, 2004).

Yin, R. (1989a). Case study research: Design and methods (Rev. ed.). Beverly Hills, CA: Sage Publishing.

Yukl, G.A. (1994). Leadership in organizations (3rd end). Englewood Cliffs, NJ: Prentice Hall.

Yukl, G., Guinan, P.J., \& Sottolano, D. (1995). Influence tactics used for different objectives with subordinates, peers, and superiors. Group and Organizational Management, 20(3), 272-296.

Zimmerman-Oster, K., \& Burkhardt, J.C. (2001). Leadership in the making: Impact and insights from leadership development programs in U.S. colleges and universities. Retrieved January 10, 2007 from the Kellogg Foundation Publication Web site: http://www.wkkf.org/pubs/cct/leadership/pub3165.pdf 


\section{Appendix A}

\section{West VurginiaUniversity}

College of Human Resources and Education

February 28,2011

Dear Marietta College,

My name is Dennis McNaboe, and I am a West Virginia University (WVU) doctoral student and Dean of Campus Life at Alderson-Broaddus College. I am exploring the relationship between attending the Marietta College McDonough Leadership program and leadership development. The purpose of this study is to explore the relationship between participation in the Marietta College McDonough Leadership program and student leadership development. Consideration is also given to the relationship between gender, major, race and ethnicity, and participation in experiential learning and student leadership development.

With your permission, I would like to utilize the results of the SLPI - Self and SLPF - Observer from freshman during the 2007-2008 and 2008-2009 years and seniors in the 2010-2011 and 2011-2012 graduating classes. In addition I would like permission to gain additional demographic data from the participants including gender, race, major, and participation in experiential learning opportunities.

This research is being conducted to fulfill the requirements for a doctoral dissertation in Educational Leadership Studies in the Department of Advanced Educational Studies at West Virginia University, under the supervision of Dr. Kimberley Yousey and Dr. Richard Walls. I am also conducting this research with the approval of WVU's Institutional Research Boards (IRB). Hence, all names of student participants will remain anonymous in the final report.

Other than access to your participants, there is no other expectation for Marietta College. All results of this research will be provided to Marietta College. Any additional documentation requested will be provided as needed.

Should you have any questions or concerns, please contact me via telephone at 304-457-6213 or via email at mcnaboedj@ab.edu.

Sincerely,

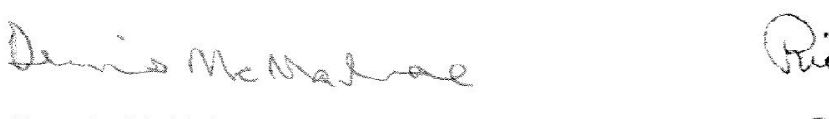

Dennis McNaboe

Doctoral Student

West Virginia University

Dr. Richard Walls

Principal Investigator

West Virginia University 


\section{Appendix B}

\section{(\$) \\ Marietta College}

May 23, 2011

To Whom it May Concern:

I am writing to confirm that the study titled the Efficacy of Marietta College's McDonough Leadership Progrom on the Leadership Development of College Students being conducted by Dennis McNaboe was approved by the Human Subjects Committee at Marietta College on April 7 of this year. Please feel free to contact me with any questions regarding our review of this research.

Sincerely,, 2

$j^{\prime}$

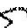

Mary V Bărnas, Ph.D.

Professor of Psychology

Chair, Human Subjects Committee

Marietta College 
Appendix C

\section{W. WestVirginiaUniversity.}

Office of Research Compliance

IRB Protocol - Non Human Subjects Research

To: Walls, Richard

From: WVU Office of Research Compliance

Date: Friday, March 18, 2011

Subject: Non Human Subject Research Acknowledgment

Tracking \#: H-23059

Title: Efficacy of Marietta College's McDonough Leadership Program on the Leadership Development of College Students

Thank you for your submission to the West Virginia University Institutional Review Board (IRB).

It has been determined that your project does not meet the definition of human subject research.

A. In order to be considered human subject research, individually identifiable private information must be obtained or used in the research. If there is no individually identifiable private information involved, the project is not human subject research and does not required being submitted to the Office of Research Compliance. Private information must be individually identifiable (i.e., the identity of the subject is or may be readily ascertained by the investigator or someone else associated with the information) in order to constitute research involving human subjects on-Human Subject Research Checklist (211l) Board Designee: Ast, Lilo

If you have any questions, please contact the IRB at (304) 293-7073.

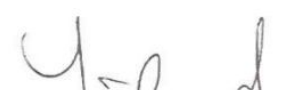

Board Designee: Ast, Lilo

Letter Sent By: Ast, Lilo, 3/18/2011 4:54 PM 


\section{Appendix D}

Instructions:

On the next page are 30 statements describing various leadership behaviors. Please read each statement carefully. Then rate yourself in terms of how frequently you regularly engage in that behavior.

This is not a test (there are no right or wrong answers). The usefulness of the feedback from this inventory will depend on how honest you are with yourself and how frequently you actually engaged in each of these behaviors.

Consider each statement in the context of your leadership development.

The rating scale provides 5 choices:

1. If you RARELY or SELDOM do what is described in the statement, write the number 1 in the space provided.

2. If you do what is described ONCE IN A WHILE, write the number 2

3. If you SOMETIMES do what is described, write the number 3.

4. If you OFTEN do what is described, write the number 4.

5. If you VERY FREQUENTLY or ALMOST ALWAYS do what is described, write the number 5 .

In selecting the response, be realistic about the extent to which you actually engage in the behavior regularly. Do not answer in terms of how you would have liked to have behaved or in terms of what you should have done. Answer in terms of how you typically behave.

Please respond to every statement. 


\section{Student Leadership Practices Inventory: Self}

How frequently did you engage in the following behaviors and actions? Write the number to the right of each statement, using the scale below, that best applies.

1=RARELY or SELDOM 2=ONCE IN A WHILE 3=SOMETIMES 4=OFTEN 5=VERY FREQUENTLY I...

1. Set a personal example of what I expect from other people

2. Look ahead and communicate about what I believe will affect others

3. Look around for ways to develop and challenge others participants' skills and abilities

4. Foster cooperative rather than competitive relationships among the people I interact with

5. Praise people for a job well done

6. Spend time and energy making sure others adhere to the principles and standards shave agreed upon

7. Describes the ideal capabilities of others

8. Look for ways that other participants can try out new ideas and methods

9. Actively listen to diverse points of view

10. Encourage others

11. Follow through on the promises and commitments I make

12. Talk with new students about sharing a vision of how much better the future can be

13. Keep current on events and activities

14. Treat others with dignity and respect

15. Support others and express appreciation for their contributions

16. Find ways to get feedback about how my actions affect other people's performance

17. Talk with other students about how their interests can be met by working toward a common goal

18. When things do not go as expected, I ask, "What can I learn from this experience?"

19. Support the decisions that other students make on their own

20. Make it a point to publicly recognize others who show a commitment to the same values

21. Build consensus on an agreed-upon set of values

22. Am upbeat and positive when talking about what the group can achieve

23. Make sure that goals are set and specific plans are made

24. Give others a great deal of freedom and choice

25. Find ways to celebrate accomplishments

26. Talk about the values and principles that guide the actions I take

27. Speak with conviction about the higher purpose and meaning of what we are doing

28. Take initiative in experimenting with the way things are done

29. Provide opportunities for others to take on leadership responsibilities

30. Make sure that other students were creatively recognized for their contributions

Copyright $\odot 2005$ James M. Kouzes and Barry Z. Posner. All rights reserved. Used with permission. 


\section{Appendix E}

Instructions:

On the next page are 30 statements describing various leadership behaviors.

Please read each statement carefully. Then rate the student you are observing in terms of how frequently you saw this student engage in this behavior.

Consider each statement in the context of your leadership development.

The rating scale provides 5 choices:

1. If you RARELY or SELDOM do what is described in the statement, write the number 1 in the space provided.

2. If you do what is described ONCE IN A WHILE, write the number 2

3. If you SOMETIMES do what is described, write the number 3.

4. If you OFTEN do what is described, write the number 4.

5. If you VERY FREQUENTLY or ALMOST ALWAYS do what is described, write the number 5 .

In selecting the response, be realistic about the extent to which you actually engage in the behavior regularly. Do not answer in terms of how you would have liked to have behaved or in terms of what you should have done. Answer in terms of how you typically behave.

Please respond to every statement. 


\section{Student Leadership Practices Inventory: Observer}

How frequently did the student you observed engage in the following behaviors and actions? Write the number to the right of each statement, using the scale below, that best applies.

1=RARELY or SELDOM 2=ONCE IN A WHILE 3=SOMETIMES 4=OFTEN 5=VERY FREQUENTLY I...

1. Set a personal example of what I expect from other people

2. Look ahead and communicate about what I believe will affect others

3. Look around for ways to develop and challenge others participants' skills and abilities

4. Foster cooperative rather than competitive relationships among the people I interact with

5. Praise people for a job well done

6. Spend time and energy making sure others adhere to the principles and standards we have agreed upon

7. Describes the ideal capabilities of others

8. Look for ways that other participants can try out new ideas and methods

9. Actively listen to diverse points of view

10. Encourage others

11. Follow through on the promises and commitments I make

12. Talk with new students about sharing a vision of how much better the future can be

13. Keep current on events and activities

14. Treat others with dignity and respect

15. Support others and express appreciation for their contributions

16. Find ways to get feedback about how my actions affect other people's performance

17. Talk with other students about how their interests can be met by working toward a common goal

18. When things do not go as expected, I ask, "What can I learn from this experience?"

19. Support the decisions that other students make on their own

20. Make it a point to publicly recognize others who show a commitment to the same values

21. Build consensus on an agreed-upon set of values

22. Am upbeat and positive when talking about what the group can achieve

23. Make sure that goals are set and specific plans are made

24. Give others a great deal of freedom and choice

25. Find ways to celebrate accomplishments

26. Talk about the values and principles that guide the actions I take

27. Speak with conviction about the higher purpose and meaning of what we are doing

28. Take initiative in experimenting with the way things are done

29. Provide opportunities for others to take on leadership responsibilities

30. Make sure that other students were creatively recognized for their contributions

Copyright @ 2005 James M. Kouzes and Barry Z. Posner. All rights reserved. Used with permission. 